\title{
ELUFILOSOOFIA JA AJALOOTEADUS BALTIMAADES: NIETZSCHE KUI REINHARD WITTRAMI TUNNISTAJA Lisandusi ajaloolaste Nietzsche-retseptsioonile ja ühtlasi nn historismikriisi problemaatikale
}

\begin{abstract}
Mart KIVIMÄE
Tallinna Pedagoogikaülikooli Rahvusvaheliste ja Sotsiaaluuringute Instituut, Estonia pst 7, 10143 Tallinn, Eesti; kivimae@iiss.ee

Artikkel käsitleb baltisaksa ajaloolase ja ajalooteaduse teoreetiku Reinhard Wittrami (1902-1973) käsitust historismist kui oma teaduse põhimõistest ja moodsa kultuuri ühest võtmeprobleemist tema 1920.-30. aastate ajaloolis-poliitilise publitsistika ning 1950.-60. aastate teaduslike tekstide uue interpretatsiooni alusel. Otsustava tegurina historismi kui ajaloolise relativismi probleemi mõistmisel rõhutatakse Friedrich Nietzsche elufilosoofilise historismikriitika mõju Wittramile, mis on tekstide võrdleva analüüsi põhjal tema artiklites tuvastatav vähemalt alates 1934. aastast kuni 1967. aastani (loengutes kuni 1969). Käsitluse eesmärk on taastada Wittram, kes ühena vähestest XX sajandi tõsiajaloolastest osaleb märkimisväärsel tasemel kaasaegses Nietzsche-retseptsioonis, sellega ühtlasi 1980.-90. aastail taaselavnenud ja rahvusvahelistunud, praeguseni kestvasse historismidiskursusse. Sellest diskursusest kõrvale- või õigemini väljajäämine on oluliselt tingitud Wittrami rahvussotsialistlikust minevikust, millele käesolevas artiklis heidetakse osaliselt mittetraditsiooniline pilk, püüdes selgitada tema vastuolulist ja iseennast kriitiliselt ümberhindavat teed varasest rahvametafüüsikast hilisema kultuurilis-poliitilise relativismini. Laiemas historiograafilises kontekstis tõstatatakse küsimus vajadusest analüüsida Wittrami loomingut senisest mitmeaspektsemalt, vabastada Wittram ajaloolasena sotsiaalpoliitilisest ja rahvusideoloogilisest tüpiseerimisest.
\end{abstract}

\section{EELMÄRKUSED ${ }^{1}$ \\ Probleemajalugu ja retseptsiooniloogika}

Kui heita ülevaatlik pilk viimase poolteise sajandi ajalookultuurile, et otsida Friedrich Nietzsche osale võrdluskuju, siis tekib mõneti paralleel Walter Benjamini

\footnotetext{
Käesolevas artiklis olen vähesel määral kasutanud oma veel käsikirjas oleva, eeldatavalt 2005. aastal avaldatava monograafia "Ajaloolise objektiivsuse probleemid" II peatükis välja töötatud seisukohti ("Elufilosoofilise historismikriitika tulemused: Friedrich Nietzsche ja küsimus ajalootunnetuse orientatsiooni järele"). Esmakordselt vaatlesin tavalisest mitmeplaanilisemalt Nietzsche suhteid historismiga 1992/93. aastal Ajaloo Instituudis EHI üliõpilastele peetud loengukursuses historismi ajaloost. Vastavat temaatikat olen varem puudutanud ka "Ecce homo" eestinduse ajendil kirjutatud artiklis "Friedrich Nietzsche ja postsotsialismi hing" (vt Kultuurileht, 1996, 30. august).
} 
rolliga: Nietzsche on nagu XIX sajandi Benjamin, ja vastupidi, Benjamin oleks nagu XX sajandi Nietzsche. Nii suvaline kui see kõrvutus ka ei tundu, on selles ajaloolise mõtlemise arengu koha pealt oma sisu: nad mõlemad apelleerisid omas ajas senisega võrreldes hoopis teistsugusele ajaloopildile, tehes seda väga radikaalse kriitika vormis suhteliselt konformse ajaloolise teaduse ja kultuuri taustal. Oma kriitilise käitumisega aitasid nad niiviisi kaasa sellele, et ajaloo üle mõtlemise vallas - teisisõnu: ajaloolise identiteedi mõtestamisel - said tekkida uued mõtteviisid. Aja jooksul osalesid nende mõtted protsessis, mille kulus toimub lõpuks "uue sünd", kui kasutada Thomas S. Kuhni teadusteooria väljendit. Kumbki neist oma ajastu "ajakohatuist" aktualiseeris ka teadusliku ajalookäsitluse loojate poolt kõrvale tõrjutud müüdi ja ajaloo vahekorra problemaatika moodsa eksistentsi mõtestamisel: Nietzsche tegi seda psühholoogilises, Benjamin sotsioloogilises võtmes. XXI sajandi alguseks juba võrdlemisi laia leviku saanud idee, et kultuurilugu ise on müïdimaastik, kus otsime seda inimese ja maailma pilti, mida võiks lugeda tõeliseks, pärineb nende juurdleva mõtte arsenalist. See aga tähendab, et Nietzsche ja Benjamin, osaliselt tema ideede vastuvõtja ja tõlgendaja, on kutseliste ajaloolaste institutsioonile ka midagi sellist nagu kriitilise ajaloomõtlemise saadikud historismi eriteadusliku paradigma ümbrusest.

On üksikuid tänapäeva ajalooteooria nägu määravalt kujundavaid autoreid, nagu näiteks Jörn Rüsen, kelle viimase aja töödes on Nietzsche ja Benjamin nihkunud tema vestluspartnerite hulka "elava meenutuse" ja "protseduurilise teaduse" üksteisest võõrandumise ning "ajaloo mõtte" kadumise probleemides. ${ }^{2}$ Või Nietzsche kunagises koduülikoolis ajaloofilosoofia alal töötav Emil Angehrn, kes on näinud Benjaminis Nietzsche kriitika jätkajat ja arendajat, ka "Nietzschest kaugemale" minejat vastavalt kultuuri "muutunud olukorrale": "Kui juba Nietzsche oli otsinud ajaloosuhet teispool ajaloofilosoofiat ja historismi, siis Benjamin laiendab Nietzsche kriitikat, allutades sellele mitte ainult kaasaegse marksismi - nii sotsiaaldemokraatia kui stalinismi - progressiusu, vaid ka historismi elufilosoofilise ületamise enese." "3 Me täheldame aga, et selliste hinnangute puhul liigub tänaste autorite interpreteeriv mõte uuseuroopaliku ajalookäsitluse "peajoonte" kontekstis, see ei haara veel kaasa regionaalsete erijoonte spektrit, milles on olemas "vastukaja" neile peajoontele. Ent ka vastukaja on keerulise struktuuriga protsess, mitte ajas hetkeline kaik või peegelduse mehaaniline akt, ta on ideede ja teoste sotsiaalse ringkäigu produktiivne koostisosa.

See, kas Nietzsche puhul on tegemist elufilosoofilise "historismi ületajaga", on ajalooteaduslik probleem, mille võib jaotada mitmeks alaprobleemiks ka vastavalt historismi kui üleeuroopaliku nähtuse rahvuskultuurilistele avaldusvormidele ja neis vormides esinevale Nietzsche-retseptsioonile. Veel enam, neiski vormides võivad olla jälgitavad diferentsid, XX sajandi lõpu uus ameerika historism (nn uushisto-

\footnotetext{
2 Vt nt Rüsen, J. Historische Methode und religiöser Sinn - dialektische Bewegungen in der Neuzeit. - Ders., Geschichte im Kulturprozess. Köln, Weimar, Wien, Böhlau Verlag, 2002, 12 jj.

3 Angehrn, E. Geschichtsphilosophie. Stuttgart, Berlin, Köln, Verlag W. Kohlhammer, 1991, 169.
} 
ritsism) rõhutab vanast saksa ja itaalia historismist rohkemgi "eristamise loogikat", tähendab, "mitte ainult erinevusi kultuuride vahel, vaid ka erinevusi ühe kultuuri piires". 4

Ühe sellise probleemi ja oma kriitilise eeskuju kaudu on Nietzsche seotud ka balti moodsa ajalookirjutuse suurkuju Reinhard Wittrami (1902-1973) - poliitiliselt vastuolulise - kaasusega balti regionaalses ajaloopildis, mille raames veel 1900. aasta ümber, ta sünniaja paiku, oli baltlastele siduv Goethe-ajastu traditsioon. ${ }^{5}$ Võib öelda, et noor Wittram allutas nietzschelikule kriitikale baltisaksa regionaalse ajalookäsituse, kuid otsis vanas eas Nietzschelt koguni tuge regionalistliku ajaloovaate teaduslikuks säilitamiseks - Nietzsche tähendus näib olevat talle ajas muutunud. Kui me räägime Wittrami Nietzsche-retseptsioonist, siis ei saa seda kohe võtta baltisaksluse kui mingi arvatavalt vanamoelise kultuurikogukonna liikmele omase retseptsiooni loogikaga. Nietzschel on baltisaksa modernsuses olemas koht eri põlvkondade ja mentaliteetide jaoks. Siin pakub huvi määrata Nietzsche koht Wittrami ajaloomõtlemise "näitajana", sellisena on kohamäärang lahutamatu historismi arengust XX sajandil. Autorid, kes mainivad põhjendatult tema konservatiivsust, jätavad esile toomata, et juba varakult tõi Wittram poliitilisse kõnelusse "ketseri” teema baltluses - see aga näitab, et tema isiklik konservatiivsuse mall on modernne, mitte vana või endine. Wittrami tekstides pole samal ajal märkimisväärseid jälgi literaarsest või poliitilisest nietzscheanismist: ei "I maailmasõja generatsioonile" tüüpiliseks peetud "Zarathustra-austusest" ega ka “"võimutahte' ära proovinud" natsiriigi "Nietzsche-karikatuurist". ${ }^{6}$ Et ta ei piirdunud Nietzsche mõttemotiivide ülesvõtmisega regionalismi kontekstis, osutavad mitmed viited tema poolt loetud soliidsetele Nietzsche-uurimustele (Jaspers, Löwith). Sel näib olevat avaram maailmavaateline taust, sest kuigi Wittram pidas end ajaloolaseks ja mitte filosoofiks, torkab ometi silma ta loengutes-artiklites üha peegelduv huvitatus eksistentsifilosoofilisest inimesekäsitusest ning sellele vastav lugejaeelistus.

Et hoiduda spekulatiivsetest ülepaisutustest, on mõistlik kõnelda kontaktist, seega Wittrami Nietzsche-kontaktist, selle kontekstist ja probleemidest, millele selline kontakt valgust heidab. Me saame kõnelda ja peame kõnelema enamastki - Nietzsche osast Wittrami ajaloolise mõtlemise struktuuris, sest nietzschelik suhe

${ }^{4}$ Scholtz, G. Einleitung. - Historismus am Ende des 20. Jahrhunderts. Eine internationale Diskussion. Hrsg. von G. Scholtz. Berlin, Akademie Verlag, 1997, 8.

5 Vt selle kohta Petersen, O. v. Goethe und der baltische Osten. Reval, Verlag Kluge \& Ströhm, 1930; vrd ka sama teose 4. lisas (219 jj.) ära toodud Goethe-biograafi Albert Bielschowsky (1847-1902) kirju Burchard von Schrenckile aastaist 1899/1900. - Siin ei saa jätta mainimata ka ühe Eestist pärit suurima kultuuriloolase Viktor Hehni (1813-1890) kuulsaid Goethe-interpretatsioone: Hehn, V. Gedanken über Goethe (1887). Neue Ausg. mit einem Nachw. von A. Eggers. Darmstadt, Otto Reichl Verlag, 1921.

${ }^{6}$ Löwith, K. Nietzsche, nach sechzig Jahren (1956). - Ders., Gesammelte Abhandlungen. Zur Kritik der geschichtlichen Existenz. 2., durchges. Aufl. Stuttgart, Berlin, Köln, Mainz, W. Kohlhammer Verlag, 1969, 127. 
ajalukku on ta mitme teksti varjund. Uue küsimuseasetuse raames ei saa me aga väita, et Wittrami kokkupuude Nietzschega on Wittrami-uurimises selle seniavastamata dominant, seda mitte. Küll aga saab väita ja tõendada, et sellel kontaktil on laiemas historiograafilises plaanis omamoodi seadistav või ümberseadistav roll ja toime, sest lisab tervikpildile Wittramist sealt puudu oleva elemendi. Järelikult pole mitte üksnes pilt Wittramist kui ajaloolasest selle Nietzsche-kontakti teadmise võrra süsteemsem, vaid ka meie pilt regiooni lähiminevikust on sellega dialoogilisem. Dominandi asemel on niisiis tegu pigem märgiga ühest loost, mis teatab elufilosoofia ja ajalooteaduse kohtumisest Baltikumi poliitilises ajaloos. See on mõtete saatuse lugu, mis on "XX sajandile" kui ajastule iseloomulik, kuid mida sajandi ideoloogialeeride konfliktide tagant pole balti (idee)ajaloos sellisena märgatud. Ka on see tõenäoliselt Nietzsche enda, veel enam ta pärandi ekspluateerijate ja poliitilise nietzscheanismi avalduste kahtlase maine tõttu oma ajasituatsiooni jäänud.

Ühele Wittrami-sugusele pühendunud teadusmehele, "ajaloohuvi" teoreetikule (1950-ndate lõpul), ajalooteaduse kui "refleksiooniteaduse" pooldajale (1970-ndate algul), kes orienteerus eeskujulikult (juba 1930-ndail) ka oma teadusharu geneesis ja alustes, austas klassikalist "Herderi liini" ja baltisaksa ajalookirjutuse seoseid "Ranke vaimuga" (läbi "Waitzi koolkonna"), kuulus pärast II maailmasõda Ranke-nimelise akadeemilise seltsi (natsismiga seotud) juhtivliikmete hulka, on see mõneti erandlik kontakt. Kontakti mõningast erandlikkust võiks toonitada kas või sellise näitega, et nii kompetentne mõtteloolane nagu Hermann Glockner on - raske uskuda - Nietzsche kohta kirjutanud järgmist: "Ka ajaloost ei omandanud ta mitte kunagi [niemals] õiget arusaamist. Ta õppis seda tundma peamiselt antikvaarsest küljest; eepiline vool, mis kannab sündinud ajaloolast, jäi Nietzschele võõraks.," Glockneri üldistava väite, mida saadab nending, et "ka Jacob Burckhardt ei paistnud talle hiljem hoopiski mitte [keineswegs] ainult Ranke ja Diltheyga võrreldava suurejoonelise ajaloolasena", võib küll ümber lükata, tuletades meelde, et Nietzsche oli vaimustatud Thukydidesest ning oskas hinnata Polybiost ja Niebuhri. Võib ka osutada Edgar Salini enam-vähem samal ajal tehtud täpsustusele: "Täiesti Burckhardti vaimule vastab seejuures Thukydidese kõrge hindamine ka Burckhardt asetab ta Platonist kõrgemale -, ja on tunda "Kreeka kultuuriloo" lähedust, kui Nietzsche ülistab Thukydidest..."8 Aga see ei tee Glockneri tüüpi populariseeritud üldistusi olematuks. Eesti ainsa Nietzsche-biograafia autori kinnitus, et "ta (Nietzsche) pidas ju ajalugu objektiivse teadusena võimatuks", ${ }^{9}$ laseb teadusliku objektivismi (kui dogmaatilise mõttevormi) vaimust vallatule samuti

7 Glockner, H. Die europäische Philosophie von den Anfängen bis zur Gegenwart (1958). 5. Aufl. Stuttgart, Philipp Reclam jun., 1980, 1026.

${ }^{8}$ Salin, E. Vom deutschen Verhängnis. Gespräch an der Zeitenwende: Burckhardt-Nietzsche. Hamburg, Rowohlt, 1959, 108.

9 Toomus, Fr. Friedrich Nietzsche. Üliinimese kuulutaja. (Suurmeeste elulood, 30.) Tartu, Eesti Kirjanduse Selts, 1936, 73. 
paista ajaloolase kontakti "sellise" filosoofiga ebatavalise kõrvalepõikena. Tervikuna pole kerge rekonstruktiivselt määratleda Nietzsche suhtumist XIX sajandi ajaloolaste töödesse, mis arvamuslikult justkui "on teada". Selles, mida ta on kelleltki lugenud või kuidas ta kellestki mõtleb, on kohati palju ebaselget, vaid märkelist ja vihjelist (nt Ranket mainib Nietzsche avaldatus 3, pärandis aga 7 korda). ${ }^{10}$

Kogu see mitmeti vastuoluline intellektuaalne taust, mis ümbritseb Nietzsche vahekorda ajaloo ja ajaloolastega ning mida omakorda pingestab tema enese kohatine posöörlus kas "ajaloomeele" või "teaduskäituse" hindamisel, on historiograafiliselt komplitseeritud. Esmalt näib olevat mõttekas vaadelda Wittrami Nietzsche-konteksti regionaalse ajaloo ja kultuuri probleemina (I), siis hõlmata Nietzsche-järgse Wittrami astmeid avaramalt retseptsioonilooliste diskussioonide tasandilt (II), lõpuks kirjeldada Wittramile eriomast suhet Nietzsche pärandisse tema kaasaegse professionaalajaloo üldise Nietzsche-pildi taustal (III).

"Baltisaksa ajalookirjutuse ajaloos" (1986), selles peaaegu 14 aastat pärast Wittrami surma ilmunud kõige mõõduandvamas ja hästi dokumenteeritud teoses, mille kontseptsiooni aga ei kuulu ajaloolaste mõjuloolise tausta avamine, on Wittram loomulikult esiplaanikuju. Kuid niisama loomulikult, ülevaateteose kontseptsioonile vastavalt, ei saa selles olla jälge Wittrami Nietzsche-kontekstist. Väljaandja Georg von Rauch (1904-1991) on osutanud baltisaksluse avaramale, "eksistentsiaalsele" kontekstuaalsusele ning sellega balti ajalookäsitluses kultuurija võimupoliitiliselt läbi aegade tugevasti seotud (kui mitte tüüpilisele) "õigustusteesile": "Ajalooteadvus sai eksistentsilise tähenduse - ajalugu kui eksistentsi õigustus." "11 Baltlaste ajaloolise ideoloogia tollest suurkontekstist pole tegelikult lahutatav ka Wittram, aga tema tõi sellesse konteksti uue ajaseisundi problemaatika. Oma Nietzsche-seotuse läbi, oma muljetega Nietzsche traktaadist "Ajaloo kasust ja kahjust elule" $(1873 / 74)^{12}$ andis ta etnoajaloolise ideoloogia küsimusele

10 Vt nt Gerhardt, V. Leben und Geschichte. Menschliches Handeln und historischer Sinn in Nietzsches zweiter "Unzeitgemässer Betrachtung" (1984). - Ders., Pathos und Distanz. Studien zur Philosophie Friedrich Nietzsches. Stuttgart, Philipp Reclam jun., 1988, 144 ja 161.

11 Rauch, G. v. Vorwort. - Geschichte der deutschbaltischen Geschichtsschreibung. Hrsg. von G. v. Rauch (unter Mitw. von M. Garleff, J. v. Hehn, W. Lenz). (Ostmitteleuropa in Vergangenheit und Gegenwart, 20.) Köln/Wien, Böhlau Verlag, 1986, XII.

12 Edaspidi järgin selle teose viitamisel Nietzsche-kirjanduses aktsepteeritud pruuki: viide artikli tekstis originaali pealkirja lühendiga $(H L)$, järgnev number märgib teose peatükkide numeratsiooni (1-10), mitte raamatu lehekülge. Kasutanud olen nii Colli-Montinari kui ka SchlechtaFrenzeli (põhimõtteliselt autoriseeritud tekstikujuga) editsioonidel baseeruvaid väljaandeid: Nietzsche, F. Unzeitgemässe Betrachtungen. Zweites Stück: Vom Nutzen und Nachteil der Historie für das Leben. - Ders., Werke, Erster Teil. Nachdruck der zweibändigen Ausgabe der Hanser Bibliothek auf Grund der dreibändigen Ausgabe von K. Schlechta, hrsg. von I. Frenzel (1967/81). Frankfurt a. M., Zweitausendeins, 1999, 113-174; Nietzsche, F. Vom Nutzen und Nachtheil der Historie für das Leben. München, Deutscher Taschenbuch Verlag, 1996, 3-123. Teose tekkelugu biograafilisel taustal on äärmise üksikasjalisusega käsitlenud Jörg Salaquarda, vt Salaquarda, J. Studien zur Zweiten Unzeitgemässen Betrachtung. - Nietzsche-Studien. Internationales Jahrbuch für die Nietzsche-Forschung. Hrsg. von E. Behler, M. Montinari, W. Müller-Lauter, H. Wenzel. 1984, 13. Berlin/New York, Walter de Gruyter, 1984, 1-45. 
modernse kriisiaja värvingu. ${ }^{13}$ See muudab baltlasena "1919. aasta põlvkonda" liigitunud, eluajaks partikulaarse identiteeditunde säilitanud ja sotsiaalset progressi kultuurikriitilise pilguga vaadanud Wittrami suhete väljaselgitamise Nietzsche pärandiga teaduslooliselt huvitavaks spetsiaalteemaks.

\section{WITTRAMI NIETZSCHE-KONTEKSTI PROBLEEM Nietzsche ja baltisaksa kaasaegsed (Fenomen "Nietzsche")}

Reinhard Wittrami Nietzsche-kontekstil on olemas vähemalt kolm arvesse ja arvestada tulevat mõõdet: (1) baltisaksa üldine kultuurkondlik miljöö ehk kultuuriline mõõde, (2) Wittrami ideoloogiline aktiivsus tema loometegevuse algperioodil Riias ja rahvaajaloo teaduslik kontseptualiseerimine ehk poliitiline mõõde, (3) Nietzschega kutseliste ajaloolaste poolt loodud distantseerituse tunde ületamiskatse ehk teaduslik mõõde. Viimane seondub juba enam Wittrami akadeemilise tegevuse hilisperioodiga Göttingenis, juhib meid oma teema teadusloolise aktuaalsuse juurde. Hiline Wittram liigitas Nietzsche nende oluliste mõtlejate hulka, kelle tõttu ei saa vastata küsimusele, "mis on ajalugu", enam nii lihtsalt, nagu seda võidi teha Hegeli ajal. "Hegeli ja meie vahel seisavad Karl Marx, Sören Kierkegaard ja Friedrich Nietzsche; kogu historism kui uurimispraktika ja meetodiõpetus; Lutheri ning tema ammuaegse ja praegusajani läbi kumava ajalookäsituse taasavastamine [...]. Kui me teadvustame maailmaajalugu saatusena, siis ei nähtu tema 'totaalsus' - nagu seda võis mõista Hegel - üldise vaimu iseenda-juurdetulekuna, vaid pigem hõlmava ja mitte taibatud üldisuse väljakutsena inimesele." ${ }^{14}$ Need read on 1969. aastast, aga hetkel loodava seose järgi on võimatu öelda, kas peale Wittrami isikliku kogemuse, mis laskis tal suhtuda skepsisega ajaloo olemuse "teadmisse", mängis veel kaasa Nietzsche oma 1874. aasta antihegeliaanliku "protestiga", millega ta oli selleks ajaks tuttav juba mitukümmend

13 Uuemast kirjandusest moodsa "kriisi"-topos'e kohta vt eelkõige Charles R. Bambachi sissejuhatust ("Modernsus ja kriis") oma monograafiale: Bambach, Ch. R. Heidegger, Dilthey and the Crisis of Historicism. Ithaca and London, Cornell University Press, 1995, 1-19. - Temaatika kohta üldisemalt vt Georg G. Iggersi kirjandusülevaadet ja eriti selle 2. osa ("'Historismi kriisi' käsitlev uus kirjandus", 110-115) tema artiklis: Iggers, G. G. Historismus - Geschichte und Bedeutung eines Begriffs. Eine kritische Übersicht der neuesten Literatur (1995/97). - Historismus am Ende des 20. Jahrhunderts, 102-126. - Historismi sotsiaalajalooliste tingimuste kohta, mis avavad ka mõningaid "kriisi”-teema arendamise uusi võimalusi, vt Wolfgang J. Mommseni artiklit: Mommsen, W. J. Der Historismus als Weltanschauung des aufsteigenden Bürgertums. - Dimensionen der Historik. Geschichtstheorie, Wissenschaftsgeschichte und Geschichtskultur heute. Jörn Rüsen zum 60. Geburtstag. Hrsg. von H. W. Blanke, Fr. Jaeger und Th. Sandkühler. Köln, Weimar, Wien, Böhlau Verlag, 1998, 383-394. - Poleemiliste küsimuste kohta tänapäeva historismidiskursuses, sh historismi teadusloolisel mõistmisel, vt Jörn Rüseni raamatu 2. ptk: Rüsen, J. Historismus und Historik (2002). - Ders., Geschichte im Kulturprozess, 43-72.

14 Wittram, R. Anspruch und Fragwürdigkeit der Geschichte. Sechs Vorlesungen zur Methodik der Geschichtswissenschaft und zur Ortsbestimmung der Historie. Göttingen, Vandenhoeck \& Ruprecht, 1969, 26. 
aastat? Wittrami karjäär, mis puht ajaliselt ulatub 1920. aastate lõpust 1970. aastate alguseni, jaguneb üldjoontes kolmeks põhietapiks: Riia, Poznań (Posen), Göttingen. Akadeemilised, ka isiku- ja teoseloolised seigad ei mahu siinse käsitluse raamidesse, seevastu on püütud rõhku panna ideelistele seostele ja motiividele, niivõrd kui need on Wittrami juures tema Nietzsche-konteksti suhtes praegu avastatavad ning selle kontuuride esialgsel visandamisel teadmisväärsed. Emeerituse eas 65-aastase Wittrami tunnustavad sõnad Nietzschest ja tema "tunnetuse tõest", 15 öeldud ajaloouurimise teemal kaasmaalastest publikule, on tagasikeriv juhtlõng, aimamaks üritatava kontuurjoonise vajalikkust.

Baltisaksa kultuurikeskkonnas, nagu tunnistavad memuaarid ja kirjavahetus, ei olnud Nietzsche ülemöödunud sajandivahetusel tundmatu - teda loeti ja loeti ka tema kohta. Tegelikult on baltisakslaste Nietzsche-retseptsioon XIX sajandi lõpul ja XX sajandi algul mitmeti harunev ja ka mitmetasemeline, seega omaette kulturoloogiline teema. Võrdluse loomiseks Wittrami ajaliselt hilisema ja sisuliselt teise positsiooniga on mõtet lühidalt peatuda neil retseptsiooni aspektidel, mis iseloomustavad 1840.-50. aastail sündinud baltlasi, faktiliselt Nietzsche kaasaegseid. Just nende aastakäikude inimesed elasid selle historistliku kultuuri õitseajal, mille vastu astus "ajakohatult" välja Nietzsche, samas elasid nad kaasa 1890. aastate "nietzscheanismile" ja osalesid Nietzsche-mütoloogia tekkeajas. Modernsuse üks põhiline probleem, küsimus "kõige senise" väärtusest, kultuuri muutumine probleemiks kultuuri enda jaoks, oli ka selle aja baltlastele tuttav.

Mõnel juhul võib olla siin Nietzschele teed sillutanud tema enesegi mõistete kujunemisel osalt määravat rolli mänginud eelkäija Schopenhaueri vastuvõtt muidu saksa idealismile orienteeritud baltlaste hulgas. XIX sajandi lõpul "Balti Kuukirjas" Nietzsche poeetilist loomingut retsenseerinud, tollal veel Innsbruckis, pärast Viinis professorina tegutsenud indoloog Leopold von Schroeder (1851-1920) on maininud oma pedagoogist isa kahetsemist, et olevat filosoofia alal "Hegeliga liialt palju aega kaotanud", sest hiljem "ta eelistas Schopenhauerit" ${ }^{16}$ Baltikumi saksa lugejaskonnale Schroederi poolt esmatutvustatud Nietzsche "Luuletused ja sententsid" ${ }^{17}$ mille andis 1898. aastal välja Nietzsche õde ja hooldaja Elisabeth Förster-Nietzsche (1846-1935), osutus XX sajandi esimese veerandi kõige populaarsemaks Nietzsche-kogumikuks (kuni 1927 ilmus 43 trükki!). Schroeder võis nii oma kohtumiste (Cosima Wagner) kui sõprussidemete (Houston St. Chamberlain) kaudu saada vahetult osa ka suulisest Nietzsche-traditsioonist. Aktiivse wagneriaani Schroederi suhtumine Nietzschesse, kelle ta tunnistas "ebatavaliselt vaimurikkaks kirjanikuks", oli siiski pigem negatiivne kui positiivne. Tuntavalt mängis selles kaasa ühiskondlik mõõde, "seose" nägemine tollase poliitilise "anarhismi" ja "paljuimetletud nüüdiskirjanduse" vahel. Nõnda siis hindas Schroeder Nietzsches

15 Wittram, R. Die moderne Geschichtsforschung und die baltische Tradition. - Jahrbuch des baltischen Deutschtums, 1968, XV. Hamburg, Harry v. Hofmann Verlag, 1967, 57.

16 Schroeder, L. v. Lebenserinnerungen. Hrsg. von F. v. Schroeder. Leipzig, H. Haessel Verlag, 1921, 38.

17 Schroeder, L. v. Neue Belletristik (Friedrich Nietzsche, Gedichte und Sprüche. [u. a.]). - Baltische Monatsschrift [edaspidi: BM], 1898, XLVI, 274-279. 
andekat "keelekunstnikku", pidamata teda filosoofina "tõsiseltvõetavaks", sellest hoolimata ei saanud Schroeder enne ta luuletuste juurde asumist jätta üles lugemata ja taunimata "moodsat tarkust" - Zarathustra põhimotiive. Nietzsche vaimsuse "patoloogilisest iseloomust" rääkides paistab Schroeder mõtlevat korraga nii meditsiinilisele kui sotsiokultuurilisele aspektile, "täielik hullumeelsus" oli talle kristliku moraali tühistamine. Võimalik, et Schroeder oli (neli aastat pärast Weimari Nietzsche-arhiivi asutamist) ka esimene baltlasest Nietzsche-kultuse kriitik: "Aga see on kohutavalt tõsine ajamärk [...], et õnnetu mehe mälestusega harrastatakse teatud kultust, nagu oleks siin tõeliselt tegemist rahvuse, inimkonna kutsutud vaimse juhiga." 18 Schroederi suhtumise teeb huvitavaks, kui mitte prohvetlikuks see, et koos kultusliku Nietzsche-pildi kriitikaga on ta ühtlasi modernsuskriitika kriitik. Mitte aga seetõttu, et ta võrdleb modernsust "metsiku nõiasabatiga", vaid põhjusel, et näeb ka modernsuses eneses kultuurilist nõrkust. Nietzsche-tutvustusest varasemas kaastöös koduajakirjale (jaanuarist 1898), kus ta samuti arvustab Nietzsche "brutaalse egoismi evangeeliumi" ja avaldab kartust, et selline filosoofia, mis "lööb mõnitavalt näkku" inimkonna arengukäigule, "paneb troonile elaja", on ta kultuuriteadlasena muu hulgas öelnud: "Just modernsuse mõõtmatu enda ülehindamine tunnistab tema nõrkusest, ebatervusest." ${ }^{, 19}$ Schroederi antud hinnanguis peegeldub kultuurikonflikt Nietzschega, kui kasutada seda tänapäeval ärakulutatud sõna: tema kultuuriideaal oli klassikaline humanism (Goethe ja Schiller, Homeros ja Shakespeare), tema valitud uurimisala oli inimkonna religioosne kogemus eri rahvaste usundites. Nietzsche üleinimese-teooria oli Schroederi järgi "süsteemitu" filosoofia, "Zarathustras" kätkevat ajaloofilosoofilist inimese muundumise skeemi ei näi ta olevat mõistnud. Peale sellise distantseerituse Nietzsche ja tema loomingu suhtes on baltluses olemas ka näide apoloogiani ulatuvast vahenditusest ehk, õigemini öeldes, Nietzsche-lummusest. Dokumenteeritud on ühe baltisakslanna, Tallinnast pärit Isabella von Ungern-Sternbergi (1846-1915, sünd. v. d. Pahlen) isiklik (juhu)tutvus noore Nietzschega Itaalia-reisil oktoobris 1876 ja fakt, et Nietzsche saatis talle ja tema kaasreisijale pühendusega oma "Tragöödia sünni” ja "Ajakohatud vaatlused". Vabaproua Ungern-Sternberg, oma aja juhtivaid grafolooge, jäi sellega Nietzsche mõjusfääri, ta vahetas kirju Nietzsche õega ("kallis sõbratar"), käis haiget filosoofi vaatamas veel 1900. aastal pisut enne viimase surma Weimaris ning avaldas siis 1902. aastal (samas Leipzigi kirjastuses, mis andis välja Nietzsche teosed) raamatu "Nietzsche oma käekirja peegelpildis". ${ }^{20}$

18 Samas, 275.

19 Schroeder, L. v. Neue Belletristik. - BM, 1898, XLV, 169.

20 Vt Wistinghausen, H. v. Isabella Freifrau von Ungern-Sternberg, geb. Freiin von der Pahlen. Baltische Hefte [edaspidi: BH], 1960, 1, 29-48; vt ka: Zwischen Reval und St. Petersburg. Erinnerungen von Estländern aus zwei Jahrhunderten. Hrsg. von H. v. Wistinghausen. Weissenhorn, Anton H. Konrad Verlag, 1993, 134 jj; samas on (135-38) publitseeritud ka kolm kirja E. FörsterNietzschele juulist septembrini 1912. Esimeses neist Leetsest Paldiski lähistel saadetud kirjadest on põgusalt juttu adressaadi äsja ilmunud raamatust "Noor Nietzsche", viimases kirjas aga viidatakse tema külalislahkusele "suure Nietzsche valguses" (im Lichte des grossen Nietzsche). See näib osutavat juba mõningasele sõltuvusele Nietzsche õe poolt kujundatud "õilistatud" Nietzschepildist ehk "suurusesse" jõudnud Nietzschest. (Algse informatsiooni ja edasijuhatavate kirjandusviidete eest I v. Ungern-Sternbergi Nietzsche-kontakti asjus võlgnen tänu Sirje Kivimäele.) 
Selle kultuurilooliselt üsna tähelepanuväärse Nietzsche-raamatu valguses, mille grafoloogiline pealkiri võib meie aja lugejat eksitadagi, saab esmakordselt kujutleda Nietzsche olemasolu fenomenina ühe sünnipärase baltlase jaoks. Nietzsche esikteoste lugemine olevat kinnitanud preili Pahleni algselt intuitsiooni teel saadud veendumust, et talle oli langenud osaks õnn "vaadata palgest palgesse geeniust". ${ }^{21}$ Ungern-Sternbergi raamatus on lehekülgi, mis mõjuvad "Zarathustra"-jäljendusena, sest Zarathustra on talle samane Nietzschega (ja viimane on siin-seal "nagu Goethe"). Parafraas Nietzsche objektiivsuse-käsitusest, mis sajandivahetuse baltisaksa kirjasõnas võiks olla unikaalne, on selle taustal, mida tol ajal saksa erialakirjanduses arutati, täiesti probleemitu. "Kas saab meid imestama panna, kui sedavõrd autonoomne isiksus peab värvitust objektiivsusest kaunis vähe? See hinnang on tal (Nietzschel) kõigi vabade, tugevate vaimudega ühine. Eks ole ju kombeks objektiivsuse ümber kõige enam kära tõsta neil, kes ei suuda oma lamedas 'minas' leida kohta subjektile. Tõeliselt suur, suursugune loomus, mis kannab oma mõõtu endas, elab ja sureb omaenda armust ning on alati suveräänne."22 Nietzschet kui autorit võetakse sõna-sõnalt, normaalse autori ja lugeja vahelise tõlgendusruumi okupeerib austusavaldus, nii et autorit pigem dekoreeritakse kui interpreteeritakse.

Autorina oli Nietzsche enamat kui märksõna vestluses või jäljenduse objekt, kusjuures enim näib olevat meeli köitnud tema ristiusukriitika ning "härrasmoraal". Tartu ülikooli rektori Ewersi lapselaps, erudeeritud Fanny von Anrep (1842-1913; sünd v. Engelhardt), kelle laste koduõpetaja ja ühtlasi majasõber oli olnud Wittrami pärastine "akadeemiline isa" Johannes Haller, võib olla sellise Nietzsche-retseptsiooni näide. Anrep kirjutas juba 1897. aastal Rõngust: "Kui tahta mõista nüüdset aega ja kirjandust, tuleb midagi teada Nietzschest ja tema filosoofiast - ükskõik, kas see tundub kellelegi vastuvõetav või taunitav -, mõju, mida ta hakkab avaldama, on õige suur..."23 Tal endal oli õnnestunud (novembris 1896) kuulata varem Baselis töötanud teoloogi ja vahetu "Nietzsche-tundja" Julius Kaftani Berliini-ettekannet "Nietzsche ja kristlus". Anrepi lektüüri hulka kuulusid peale Nietzsche teoste ka tema kirjad, samuti esimesed Nietzschekäsitlused, niihästi kirjanduslikud (Malvida von Meysenbug) kui filosoofilised (Georg Simmel). Iseloomulik on, et lugejahuvist hoolimata olid sellele venestusaega kogenud haritud naisele Kant ja Goethe kultuuriliselt palju lähedasemad kui Schopenhauer ja Nietzsche, kes - tema sõnul - "põhjustavad dekadentsi”. Veel on aga iseloomulik, ühtlasi teiste kaasaegsete mentaliteeti esindav, kuidas akadeemilise seltskonnaga tihedalt lävinud daam jagas oma seltskonna professorite ettekujutustele vastavalt Ranke-koolkonna ja rankeanismi "üldtunnustatud" seisukohti, mille suhtes Nietzsche tekstid võisid tunduda ja tundusidki irriteeriva "vastand-

21 Vt Ungern-Sternberg, I. F. v. Nietzsche im Spiegelbilde seiner Schrift. Leipzig, Verlag von C. G. Naumann, i. a. [1902], 36 jj. (Raamatu 2. ja 3. ptk kirjeldusi kohtumistest Nietzschega on kasutatud allikana ka uusimates Nietzsche-biograafiates, vt nt Cate, C. Friedrich Nietzsche. London, Pimlico/Random House, 2003, 230 jj, 236, 566.)

22 Samas, 163.

23 Anrep, F. v. Briefe einer Livländerin aus den Jahren 1873-1909. Bearb. von G. Westermann (Schriftenreihe der Carl-Schirren-Gesellschaft, 6). Landshut, Bosch-Druck, 1990, 141. 
kultuuri" loomena. Anrepile oli Nietzsche hea ja huvitav saksa kirjanik, ent pisut kahtlane või kummaline filosoof, mitte päriselt oma. 1904. aastal kirjutas ta "tõsist" - Nietzschega võrreldes "kahvatut" - teoloogi ja (frantsiskluse) ajaloolast Paul Sabatier'd lugedes: "Võib-olla on oletus, lootus, et kõik peab lähtuvalt ühest kõigeväelisest tahtest viidama teatud eesmärgile, väga inimlikult mõeldud, aga mulle näib see ka mõistusele vastuvõetavam kui Nietzsche 'igavene taastulek', mis jääb lõpuks ju ka tõestamatuks hüpoteesiks, Nietzsche-taolise mehe kogu loogilise teravmeelsuse kiuste." ${ }^{24}$ Moodsusele kultuuris oldi ka kohalike baltlaste ringides aldis, ent reservatsioonidega, nagu nähtub Anrepi kirjamärkustest (1905, seoses Hofmannsthaliga: "need moodsad [diese Modernen], kui tarvitada mulle ebasümpaatset sõna..."), teatud sotsiaalse ja esteetilise distantsiga tunnetati "aja pulssi". Kummatigi juba Anrepi austus "agnostitsist" Darwini isiksuse ja eluhoiaku vastu näitab, et meelelt kaasaegne polnud mitte üksnes mõni metropolis Berliinis tegutsev baltisaksa päritolu religioosne modernist, näiteks Anrepi sugulane Adolf Harnack (1851-1930), kellest sai peategelane 1892. aasta kuulsas vaidluses apostliku usutunnistuse üle. Harnacki liberaal-teoloogilises historismis väljendatud mõtted legendide allikaväärtusest usundiloos ennetavad tänapäeva sotsiaalajaloo huvi mentaliteedi protsesside vastu. Wittrami kõrval on Harnack teine Baltikumist pärinev ja historismiloole tähtis ajaloomõtleja. Nietzsche "gnostitsistlike" vaadetega kristlusele kursis olnud Harnack, kes juba noorelt sai tunda Nietzsche Baselisõbra Overbecki "jämedat" kriitikat, märkis 1890. aastate kirikuajakirjanduses, et "meie sissevaade asjade relatiivsusse kasvab", koos teadmise muutumisega Stückwerk'iks konstateeris ta ühelt poolt teadusliku käsitluse, teiselt poolt "elule pidet ja jõudu" andvate "asjade ja väärtuste" vahelise lõhe suurenemist. ${ }^{25}$ Nietzsche hoiakust polnud just väga kaugel Harnacki kahtlus ajaloo konventsionaalse teaduslikkuse ("spetsialistide", "kärutajate" jms) osas, samal ajal kehastas ta selle "hariduskodanluse" kõrgkihti, mida Nietzsche ei sallinud. Harnack solidariseerus ka Dilthey elufilosoofilise historismiga, mis ajaloo uurimisel "töötab peente läätsede ja peeglitega, kutsub appi kunsti", mõistmaks ning edastamaks "üksikut inimest" teistsuguse indiviidina "elavates joontes". ${ }^{26}$ Nietzsche fenomen ei paista olevat Harnackit (kiriku)ajaloolasena eriliselt köitnud, temale jäid valitud dialoogipartneriks Augustinus ja suurimaks õpetlaskujuks Leibniz. Kolleeg Martin Radele kirjutas ta järgmist (novembris 1899): "Ma ei taha sellist teoloogiat, mis vormiliselt esitab end nii, nagu Nietzsche pakub filosoofiat - apercu-päraselt, tasakaalutult välgutades jne, metoodiliste seosteta ja ettevaatliku mõõdukuseta. Ma ei taha protestantismis teoloogiat, mis peab küsitavaks evangeelset jumalamõistet..." ${ }^{27}$ XX sajandi algul, 1909/10, pühendas eraldi traktaadi väitlusele Nietzsche eetikaga

24 Samas, 237.

25 Harnack, A. Über Wissenschaft und Religion. Angeeignetes und Erlebtes (1895). - Ders., Reden und Aufsätze, II. 2. Aufl. Giessen, Alfred Töpelmann, 1906, 371; 372 jj.

26 Harnack, A. Gedanken über Wissenschaft und Leben (1907). - Ders., Aus Wissenschaft und Leben I. Giessen, Verlag von Alfred Töpelmann, 1911, 7.

27 Tsit teosest Zahn-Harnack, A. v. Adolf von Harnack. Berlin-Tempelhof, Hans Bott Verlag, 1936, 298. 
baltlasest teoloog Reinhold Seeberg (1859-1935), tollane Harnacki noorem kolleeg Berliinis, kes on õpetanud ka Tartu ülikoolis. Seeberg oli arvamusel, et "Nietzsche mõjude aeg ei ole veel möödas", ja enamgi, et "Nietzsche mõju ei möödu enne, kui oleme saanud jagu vastuoludest, mille juures tema murdus". ${ }^{28}$ Eelkõige on nende vastuolude all Seebergil silmas peetud XIX sajandi "vastandlike kultuurikihtidena" mõistetud idealismi ja realismi järgnevust "rahva arengus". Väärib aga märkimist, et teoloogina tajus Seeberg Nietzsches ja "Jumala surma" teesis otsustavat ajastunähtust, "modernsuse" lipukirja, mitte lihtsalt teatud üksikinimese ideed, mis usuteadusele on vastuvõetamatu. Ta sai aru, et "Nietzsche ideed" koos "darvinistlike tendentsidega" mähivad endasse ühest ajajärgust teise siirduva inimese - inimese, "kes peab elama kahe ajastu vahel". ${ }^{29}$ Nietzsche esineb Seebergil mastaapsena, ta on euroopa kultuuri üleminekuajastu maailmapildi ("lõhestunud maailmapildi”) prohvet, mitte enam üks vaieldav saksa kirjanik. Eraviisilise kirjandusliku maitsega piirduv kaasaegsus, nagu Anrepil, kes pidas mõnda Nietzsche vaadet ühiskonnale "ohtlikuks", tunnistab sellest, et nn traditsiooniline ("kõrgemate") väärtuste gamma oli baltisaksa provintsimiljöös veel kogukonna haritud kihi suhteid maailmaga reguleeriv jõud või tegur.

\section{Wittrami kontrasteeriv Nietzsche-retseptsioon}

Huvitatus Nietzschest jäi sajandivahetuse paiku mingil määral paralüseerituks oma kultuuriuskumuste võimust. Need ei lasknud tekkida seda enesevõõrastust, mis imbub aegapidi enda teisitinägemisse ja näib olevat vajalik eeldus sotsiaalse identsuse problematiseerimiseks ajakulus. Kriisi- ja võõrastustunne kui ajaloolise identiteedi kompleksi kuuluv "mittemõistmine" võib aga pingeolukorras - poliitilise ideoloogia fermendina - juhtida isiku ka maailmavaatelise radikaliseerimise teele. Poliitiliselt radikaalsetes maailmavaatehoiakutes on seetõttu alati kompromissitut enesejaatust. "Lätimaa-baltlase" Wittrami teel, mis 1939. aasta omarahvuslikust ja geopoliitilisest vaatepunktist nähtuna algas sel ajal, kui "sõda ja revolutsioon purustasid Baltimaade ajaloolise ühtsuse" ning sõja eel loodetud kunstliku Baltland'i ühtsust ei olnudki, ${ }^{30}$ on selline aspekt. Identiteedi tegur, millele Wittram oma esiktekstides apelleerib, on "põlvkonnateadvus" - teadvus idealistlike uskumusteta ning 1919. aasta elamustega sõjast, ka sellest, et "irratsionaalset kogeti reaalsusena". "Kas pole siis arusaadav, et meie põlvkond hakkas maailma vaatlema sellelt hingeliselt positsioonilt...?"31

28 Seeberg, R. Alte und neue Moral. Hamburg, Agentur des Rauhen Hauses, 1910, 22. (Algselt ettekanne Sisemisjoni 35. kongressil Stuttgardis 7. oktoobril 1909.)

29 Samas, 25.

30 Vt nt Wittram, R. Baltische Lande - Schicksal und Name. Umrisse der äusseren geschichtlichen Wandlungen seit dem 13. Jahrhundert im Spiegel des Landesnames. - Baltische Lande. Hrsg. von A. Brackmann und C. Engel. 1. Bd.: Ostbaltische Frühzeit. Leipzig, Verlag von S. Hirzel, $1939,493 \mathrm{jj}$.

31 Wittram, R. Die Generation von 1919. - BM, 1928, 1, 10. 
Wittrami radikaalsuse puhul on vaja esmalt rääkida sotsioloogilise, täpsemalt suure ühiskonnaloolise sündmuse mõjust ja järelmõjust (globaalne sõda XX sajandi "algkatastroofi" mõttes, mida ei saa võtta järgnenud sõjast "isoleeritult"). ${ }^{32}$ Kuid igast mõjust saab pärismõju alles siis, kui välist sündmust - intuitiivselt või teaduslikult - töödeldes kujuneb isiksuse jaoks selle sündmuse personaalne mõjumõõde. Tõenäoselt ja erinevalt tavapoliitikust või demagoogist, kelle otsused rahva ajaloolise kultuuri üle võivad olla suvalised ja pinnalised, oli Wittrami radikaalsus tunnetuspõhine, seotud (uue põlve) ajaloolase professioonist tuleneva kompetentsiga. 1928. aastast Herderi instituudiga Riias kutsealaselt seotud Wittram elas mõnes suhtes ka intellektuaalselt küllastatumas atmosfääris. Herderi Seltsi iga-aastastel suvekursustel (1922-38) osales muljetavaldav rida Saksamaa ja teiste maade teadlasi-filosoofe, ${ }^{33}$ nii mõnigi neist (nt Rudolf Eucken või Oswald Spengler) on tuntud oma Nietzsche-sümpaatiaga. Me ei tea, kus ja mis asjaoludel puutus Wittram esmalt kokku Nietzsche kui autoriga, ka tema õpiajal Weimari vabariigis 1920-ndate algul (1920-22 Jenas ja 1922-25 Tübingenis) oli Nietzsche otsekui õhus, oli tõesti olemas midagi sellist nagu Nietzsche-õhkkond. Esindusnäiteks võib tuua tolleaegsest "vabasaksa noorsooliikumisest" malli võtnud rahvaharidusliikumise, mis Nietzsche nihilismi-teesi aktuaalsust tunnetavate noorte kasvatusteadlaste juhtimisel oli suunatud "sisemise rahvaühtsuse uuendamisele". ${ }^{34}$ Nietzschele toetuti ajakirjanduses, näiteks paljudes Lääne-Ida ja sakslaste-slaavlaste suhteid eeskätt rahvuslikul pinnal arutavais (kultuuri)poliitilistes spekulatsioonides, mille leviku taga oli tuntud kirjastaja Eugen Diederichsi aktiivsus. ${ }^{35}$ Ometigi pole ei baltlaste Saksamaa-kontaktide ega Riiat külastanud vaimuteadlaste koosseisu juures välistatud, et Nietzsche ideede üle, mis ei olnud ju saksa keeleruumis enam nii väga "ajakohatud" ega ka ainult "kultuslikud", võidi 1920.-30. aastail diskuteerida "saksa vaimutöö" institutsioonides väljaspool Saksamaad. Võimalik on samuti, et Wittram kui ajaloolane tutvus Nietzschega ühe tolle aja autoreist terasema Nietzsche-lugeja Ernst Troeltschi 1922/24 ilmunud ajaloofilosoofiliste põhitekstide ("Historismi kriis", "Historism ja selle probleemid", "Historism ja selle ületamine") vahendusel. Algusest peale torkab aga Wittrami Nietzsche-retseptsioonis silma poliitilise teema paralleelsus historismi teoreetiliste küsimustega. Üheks tema allikaks või autoriteediks 1930-ndate keskpaiku näib olevat olnud oma varajase natsisõbralikkusega tuntud rahvuskonservatiivne liberalismiloolane Otto Westphal (1891-1950), keda Wittram tsiteerib tollal läbisegi Nietzsche, Burckhardti ja Troeltschiga.

32 Vt nt Wehler, H.-U. Der zweite Dreissigjährige Krieg. Der Erste Weltkrieg als Auftakt und Vorbild für den Zweiten Weltkrieg. - Spiegel special (Das Magazin zum Thema: Die Ur-Katastrophe des 20. Jahrhunderts), 2004, 1, 138-143.

33 Vt Hehn, J. v. Das Herder-Institut zu Riga 1921-1939. - Zeitschrift für Ostforschung [edaspidi: ZfO], 1981, 4, 499.

34 Vt Flitner, W. Erinnerungen 1889-1945 (Gesammelte Schriften, 11). Hrsg. von K. Erlinghagen, A. Flitner, U. Herrmann. Paderborn, München, Wien, Zürich, Ferdinand Schöningh, 1986, 275.

35 Vt selle kohta lähemalt: Hecker, H. Die TAT und ihr Osteuropa-Bild 1909-1939. Köln, Verlag Wissenschaft und Politik, 1974. 
Kuidas sellega ka poleks, oluline ja eristav on siinjuures see, et Wittram võttis Nietzschet vastu ilmselt teisiti kui baltlasest paikkondlik saksa kultuuri tarbija varem. Mõnes suhtes oli ju ka Anrepi-sarnane - parimas mõttes - kultuuritarbija tõepoolest toosama "dekoratiivse kultuuriga" täidetud "haritud inimene" ehk kultuuriline filister nietzschelikus tähenduses (vrd HL 10). Wittramile seevastu on ajaloolise teadmise ja traditsiooni vahekord sellega, mida Nietzsche nimetab "oma kogemuste elavaks süsteemiks", juba probleemsete suhete ala. Fenomen, mis tema jaoks otsustavana on sellesse alasse sisenenud, kannab 1930. aastal Herderi instituudi vastse dotsendi suus nihilismiga ("tänase kriisiga") haakuvat nime: see on "igasugune avalik relativism". ${ }^{36}$ Viisiga, kuidas ta otsustas selle "tagasi lükata", orienteerudes "meie rahva" elamusele (Gemeinschaft' i-mudelile), Herderi-aegse rahvalikkuse kategooria ümbertõlgendatud sisule (Volkstum'i-juuretisele) ja rahvussotsialismi "liikumisele" (nn Bewegung'ile), määras Wittram paljudeks aastateks oma poliitilise saatuse. Wittrami poliitiline saatus aga varjutab tema Nietzsche-kontakti teadusteoreetilise tähenduse aastakümneteks, nii baltisaksa kui - veelgi laiemalt - saksakeelses ajaloodiskursuses. Meile lähedase Soome ajalookultuuris 1977. aastal (saksa keeles) ilmunud historiograafiliselt asjalik, ent marksismi klassihuvidega opereeriv "'historistliku' ajalookirjutuse kriisi" uurimus ei seo samuti "irratsionalist" Nietzschet ajaloolastega ega historismi kriisiga. Autori Matti Viikari arvates vaatasid ajaloolased sajandivahetusel ning I maailmasõja järel historismi "konsekventsidest" mööda, "relativismiohtu" ei tunnetatud, nii et see "tegi muret" ainult teoreetikutele, "eelkõige sellistele... nagu Ernst Troeltsch" ${ }^{37}$ Noore Wittrami vaateid rekonstrueerides ei tohiks mööda minna faktist, et Troeltschi 1924. aastal postuumselt ilmunud "Historismi ületamine", mida Wittram tundis, sisaldab kõiki teda ennastki vaevanud mõttekomponente. Need on "saabuv nihilism" (millest "Nietzsche kõneles"), "kogukonna" ja "ühisvaimu" saatus, "enesekeskne" liberalism, kui nimetada mõnda olulisemat teemat poliitika lõikumispunktis historismiga. ${ }^{38}$ Puht ideelooliselt oli Wittram kultuurilise retsipiendina - samal Nietzschest lähtuval ja Troeltschiga jätkuval tunnetuse teel, tema jaoks oli sel teel ka eriline kohalik värving.

Probleem on selles, et marksistliku sotsiaalajaloo matriitside järgi langetatav poliitiline hinnang "poliitilise ajalookirjutuse" rollile ühiskonnas on ise hegemonistlik ja ei soosi historismi eristava uurimise loogikat. Wittrami Nietzschekontekst, mis on teatav ideeline lähtepunkt tema pöördumisel kogukonna poole, lubab diskussioonis Wittrami mineviku üle tuua varjust esile historismi ambiva-

36 Wittram, R. Liberal und konservativ als Gestaltungsprinzipien baltischer Politik. - BM, 1930, 4, 230.

37 Vt Viikari, M. Die Krise der "historistischen" Geschichtsschreibung und die Geschichtsmethodologie Karl Lamprechts (AASF, Dissertationes Humanarum Litterarum 13). Helsinki, Suomalainen Tiedeakatemia, 1977, 25.

38 Vt Troeltsch, E. Der Historismus und seine Überwindung. Fünf Vorträge. Eingel. von Fr. v. HügelKensington. Berlin, Pan Verlag Rolf Heise, 1924; vrd ka liberalismi, sotsialismi ja konservatismi, sh demokraatia, imperialismi ja natsionalismi "sisemise dialektika" ning "kristluse kriisi" analüüse poliitilise eetika seisukohalt: Troeltsch, E. Deutsche Zukunft. Berlin, S. Fischer Verlag, 1916, eriti $100 \mathrm{jj}$. 
lentse olemuse kui tema ideoloogilist käitumist selgitava argumendi. "Kui Friedrich Nietzsche 1873/74 oma "ajakohatud vaatlused" "Ajaloo kasust ja kahjust" avaldas, oli sellest nähtusest, mille vastu ta võitles ning mida Ernst Troeltsch hiljem oma teoses "Historism ja selle probleemid" mõista püüdis, saanud üks tema sajandi iseloomujooni... Kunagised Venemaa Läänemereprovintsidki, ka baltisakslased on romantismi ajast saadik olnud osalised selles arengus, milles saab eristada erinevaid faase." 39 Need faasid ulatuvad XIX sajandi jooksul koduloolisest ajalooarmastusest ja -harrastusest ajalookirjutuse kaitseiseloomuni, ajaloo, õiguse ja poliitika alalhoidliku läbipõimumiseni ajaloolises mõtlemises ning "missiooni"-teadvuses. "Ja nüüd saab ajaloost, mis veel hiljuti, veel 1860. aastail oli tükike olevikku, üha enam minevik. Poliitilise eksistentsi õigustust ei ammuta järelemõtlev baltlane 1890. aastaist saadik mitte enam jõust [aus der Kraft], vaid meenutusest [aus der Erinnerung]. Ajalugu muutub lohutuseks, ja see, kes elab iseseisvast jõutundest, teeb seda koos Nietzschega [hält es mit Nietzsche], kes jälgis 'ajaloolise meele liialdusi' oma individualistliku sarkasmiga." 40 Nietzsche tarvitatud sõna Ausschweifung, mis tähendab ülemäärast, "normaalse mõõdu tugevat ületamist', iseloomustab ajaloomeelt, "mille all olevik kannatab" ja mille vastu astub välja "meie nooruse õigus" oma tuleviku nimel (HL 9; vrd 7). Wittrami tuginemine - antud juhul Eduard von Hartmanni "raukust" kritiseerivale - Nietzschele toob samas ilmsiks tema põlvkondliku opositsiooni. Tema jõu-mõiste on vähimagi kahtluseta Nietzsche poolt nii inimesele ja rahvale kui kultuurile omistatav "plastiline jõud" - "ma mõtlen jõudu endast lähtudes omalaadselt kasvada, möödunut ja võõrast ümber kujundada ja oma koosseisu lülitada..." (HL 1). Enda trööstimist ajalooga peab Wittram mõttetuks elu stagnatsiooniks poliitilise protsessi "kohutava dünaamika" ja "vana" kogukondliku teadvuse "purunemise" olukorras. Kontrast varasema kirjandusliku Nietzsche-pildiga baltluses on Wittramil iseloomustatav retseptsioonitaseme hüppelise vahetusena, selle asetumisena professionaalse ajalooteadusliku huvi suunale - historismi analüüsile. Wittram tõi Nietzsche partnerina (avalikul tribüünil ja konkreetse teosega) väitlusse oma rahvuslik-ajaloolise pärandi üle, ta nägi ajaloovaatluses nietzschelikult ka elu ja ajaloo vahelise suhte kunstlikkuse võimalust.

Gert von Pistohlkors on arvustavalt väitnud, et 1930. aastate algusest saadik olevat Wittram ajaloolisusega liialdanud. "Ja siitpeale [1934. aastast] püüdis Wittram ajaloo mõistet ülerõhutada [zu überhöhen] ning seda kõigi sakslaste hingesuguluse kategooriana - rahvaajaloo uue mõiste tähenduses - tõlgendada." ${ }^{41}$ Ma arvan, et see etniliste suhete diskursuses - 1990. aastail - esitatud väide jätab

39 Wittram, R. Geschichtsbewusstsein und Geschichtsbetrachtung im baltischen Deutschtum. Sitzungsberichte der Gesellschaft für Geschichte und Altertumskunde zu Riga. Vorträge zur Hundertjahrfeier am 6.-9. Dezember 1934. Riga, Verlag E. Bruhns, 1936, 1.

40 Samas, 5.

41 Pistohlkors, G. v. Ethnos und Geschichtsschreibung der dreissiger und vierziger Jahre in Deutschland und Ostmitteleuropa. Einführende Bemerkungen. - Zwischen Konfrontation und Kompromiss. Hrsg. von M. Garleff (Schriften des Bundesinstituts für ostdeutsche Kultur und Geschichte, 8). München, R. Oldenbourg Verlag, 1995, 20. 
soovida: see arvestab vaid osaaspekti, on üksnes osaliselt tõene ning vajab historismi aspektist täiendamist. Siin peab viitama sama autori poolt 30 aasta eest vahendatud Wittrami sõnadele tema auks koostatud pühendusteose üleandmisel (septembris 1972). “... Täienduseks oma ütlusele Liivimaa-päritolu vermivast jõust kõneles Wittram 'ajaloolise relativeerumise keerisest' [vom "Sog historischer Relativierung"] ja nägi kõige oleva ajaloolisuse kogemuses spetsiifilist ohustust endale ja paljudele tema põlvkonnast." ${ }^{42}$ See on tõde haavatud elumaailmast, seega eluilmast kui maailmast "kellegi maailma" eriomases, "omaks tehtud" maailma tähenduses ${ }^{43}$ - Wittram teadvustas niisuguse omamaailma mõningaid elemente, kirjeldades õigesti nende "kõrget eluväärtust". Kuid õige on ka, et eluväärtuste ohtu sattumisel on võimalikud mitmed käitumise strateegiad, Wittram nägi neid 1930. aastal "juhtimisprobleemi” (Führungsproblem'i) valguses. Võibolla on liialdamise alged peidus Wittrami tollase maailmapildi ülearu duaalses jaotuses - poliitilise mõtlemise liigitamises kas liberaalseks või konservatiivseks ning sellest skeemist tuletatud oludekohases arvamuses, et need (kui ajaloolised positsioonid) on üksteist välistavad maailmatõlgenduse printsiibid? Kas ei või seda sorti liialdamist täheldada juba Wittrami 1920. aastate lõpul väljendatud radikalismis: "uute vormide" taotlemises "vanade parteimõistete" tähendusetuks muutumise tõttu, "illusioonituses", skepsises "enesekindla ratsionalismi" ja "poliitilise konstruktivismi" suhtes, ja tema väites, et "ka üks õpetus on süïdi" (individualism)? ?4 $^{44}$ Võib aga ka küsida, kas ajastu hingusega üldse klapib kokku nüüdishoiak omistada Wittramile millegagi liialdamist, "ïlerõhutamist", kui vaadata tema aja joontele historismi, selle "kaasaja ühe kõige raskema ja valusama probleemi" (Troeltsch) aspektist. Historistlik teadvus pidi vaid süvendama kujutlust stabiilsuseta, kodutundeta maailmast, kus rahvuslik-kultuuriline identiteet ei ole kaitstud. Ning kas ei kirjutanud seesama liberaalne teoloog pea samal ajal skeptiliselt: "Meie lahendus ei tohi olla või mitte oluliselt olla mõeldud selle liiga harmooniauskliku ja liiga egotsentrilise liberalismi tähenduses." ${ }^{45}$

Ma arvan, et presentismi veast hoidumiseks tuleb rõhutada midagi muud, see muu on küll seoses ajaloo ja rahva mõistetega, ent rohkem sisemisse konstitutsiooni puutuv, ütleksin, mentaalne. 1928. aastal kirjutab Wittram oma põlvkonna ("meie aja laste") "sisemisest eneseteadvusest", mis tahaks "ankurdada oma väärtusmõisted" mingisse "absoluutse"-elamusse. Wittram nimetab seda tahet igatsuseks (Sehnsucht) - "igatsuseks mõõdu ja normi, väärtustuse ja uskumise järele". ${ }^{46}$ Kui me ei hakka siin spekuleerima noore ea kriiside teemal, vaid tugineme tekstialusele, siis tuleks öeldut võtta historismikriisi teadvustamisena ja vastuabinõude

42 Pistohlkors, G. v. Nachruf auf Professor Dr. phil. Reinhard Wittram (+16. April 1973). - ZfO, 1973, 4, 699.

43 Vt selle kohta: Landgrebe, L. Der phänomenologische Begriff der Erfahrung (1973/82). Ders., Faktizität und Individuation. Studien zu den Grundfragen der Phänomenologie. Hamburg, Felix Meiner Verlag, 1982, 58-70.

44 Wittram, R. Die Generation von 1919, 11.

45 Troeltsch, E. Der Historismus und seine Überwindung, 45.

46 Wittram, R. Die Generation von 1919, 12. 
otsimise alustamisena. Tuleks ka näha, et Wittrami arusaamal historismist on tema rahvaajalooliste uuringutega või rahvakeskse ajaloolise küsimisviisiga algusest peale tihe poliitiline seos - see on nagu baltisaksluse "pärisolemusele" poliitilist kehastust ja juhtimist otsiv aktiivsus. Uurida jääb veel huvitav probleem, kuivõrd on see aktiivsus maailmavaateliste tunnuste järgi liigitatav "1933. aasta eelloona" käsitatud poliitilise eksistentsialismi juurde ${ }^{47}$ sest Wittramil on kalduvus vaadata poliitika kategooriaid eksistentsiaalse nurga alt. Nüïd, kus me teame, "mis edasi sai", on igal ajaloolasel õigus kritiseerida nende otsingute mooduseid, vorme ja tulemusi, kuid vaevalt oleks mõtet nõuda kolmveerand sajandi tagant kellegi ajateadvuse parandamist või väljavahetamist. Wittram oli sellest ka ise piisava selgusega teadlik, märkides 1958. aastal ühes olulises artiklis: "Kui seosed ja konkreetsed elusituatsioonid, milles kehtis teatud poliitiline meelsus, on möödunud, relativeerub nende kehtivuspretensioon varem või hiljem." ${ }^{48}$ Siis osutas ta veel kord, et "kogu baltisaksluse traditsiooniline eksistents" oli "tohutu sotsioloogilis-poliitilise muutumisprotsessi käigus pandud küsimuse alla, seda mitmest küljest ja mitte alles alates 1933/34".

\section{Historismikriitika ja rahvametafüüsika}

Ajaloo mõiste ülemäärasele tähtsustamisele või "kõrgendamisele" osutamine ei taba selle maailmavaatelise probleemi tuuma, mille ette, tekstide järgi otsustades, nägi end asetatuna Wittram ning millega pidi tegelema - nietzscheliku eluteenimise mõttes - tema reageeriv mõtlemine. Väga teravalt koges Wittram 1930-ndail kõige ajaloostumise ja "ajaloolise perspektiivi" suurt rolli ka baltisaksa kultuuri puudutavas modernsuse kultuurilis-vaimses murrangus: normatiivse maailmapildi lagunemist ja väärtushoiakute konkurentsi tekkimist. Elu historiseerumises nägi ta seega kultuuri saatust, millest keegi ei saa kõrvale jääda. "[...] Ka meie osaleme selles saatuses, mis on määranud euroopa vaimu muutumise: õhtumaise kristluse taevas purunes ka meie kohal, seisuslik maailm varises kokku ka meie juures, kristlik-usulise alge keskaegse esimuse vahetas ka meil välja loendamatul arvul uusi absoluutseid väärtusseadeid, mille ennastunustav võitlus üksteisega ning kristluse absoluutsustaotlusega on meie kaasaja tunnus." ${ }^{49}$ 1933. aasta mais tehtud baltisaksluse "vaimse olukorra" analüüsis on Wittrami jaoks üks kesksemaid probleeme kogukondliku ühtekuuluvustunde kadu ("baltisaksa solidaarsuse lagunemine") relativismi mõjuväljas. "Maailmavaateline diferentseerumine meie rahvarühma piires ei tundu mulle soovitava, paratamatu ja loomuliku mitmekesisuse väljendu-

47 Vt Schnädelbach, H. Politischer Existentialismus - zur philosophischen Vorgeschichte von 1933 (1983). - Ders., Zur Rehabilitierung des animal rationale. Vorträge und Abhandlungen 2. Frankfurt a. M., Suhrkamp Taschenbuch Verlag, 1992, 346-355.

48 Wittram, R. Zur Beurteilung vergangener Denkweisen. - Baltische Briefe [edaspidi: BB], 1958, 8/9, 2.

49 Wittram, R. Die geistige Lage des baltischen Deutschtums in historischer Perspektive. - Baltische Monatshefte [edaspidi: BMH], 1933, 5, 250. 
sena, vaid lõpulise [vollendete] killustumisena, atomiseerumisena. Sellega pole mõeldud mitte ainult kõigi arvamuste relativeerumist, mitte ainult kujunenud erilaadi juurtetumist ja nivelleerumist. Öelgem otsekoheselt ja selgesõnaliselt: meie meelsuste killustumine ulatub nii kaugele, et erineva vaimse ja poliitilise hoiakuga baltisakslased ei tunne ennast üksteisele enam lähedastena [als verwandt]. ${ }^{, 50} \mathrm{Et}$ relativism süvendab - kommunitaarsest vaatepunktist - indiviidide võõrandumist üksteisest ja kogukonnast, on tänapäevaseski maailmas küllalt levinud (enam või vähem antiliberalistlik) poliitiline idee, mida esineb ka postsotsialistlikus Baltikumis. Kui tahta lühidalt ja tema oma sõnadega ühest 1933. aasta veebruaris ilmunud repliigist iseloomustada Wittrami Nietzsche-sfääri kuuluvat uut fenomeni, talle maailmavaateliselt ja rahvuskultuuriliselt ebasoovitavat modernsusfenomeni, siis see on "liberaalne relativism". ${ }^{51}$ Wittrami algse Nietzsche-suhte mõistmiseks on sel otsustav tähtsus: relativismi-tunnetus käivitabki Wittramil traditsioonilise historismi kriitika, kusjuures Friedrich Nietzsche ja samuti Ernst Troeltschi Nietzsche "võitles selle vastu", Troeltsch "püüdis seda mõista" - epohhiliste mõtete tähe all. Sellest on ka näha, et Wittram ei paisuta ajaloo mõistet üle, vaid toob ajaloolise kriisiteadvuse sõnumi: ajaloo mõiste, mida baltlased historistliku traditsionalismi ja maapatriotismi vaimus uskusid ja mis nende teadvuse üle valitses, on laostanud moodne relativism. Peale "moodsa (modernse)" kui ajamääratluse seonduvad Wittrami 1920.-30. aastate relativismi-epiteedid ("avalik", "liberaalne", "individualistlik" jmt) kindla poliitilise vastandusega, suunitlusega kogukonna ideele. Juba 1928. aasta esimesel poolel oli ta kirjutanud: "Kogukond ei ole tänapäeval romantiline lastemäng, vaid igati [weithin] domineeriv vajadus. ${ }^{, 52}$ Samas eelistas Wittram tükk aega (u 5-6 aastat) enne natside võimuletulekut Saksamaal panustada balti korporatiivsete struktuuride taaselustamise katsete asemel "rahva mõtleva nooruse" osalemisele "saksa rahva arengus".

Ekskursina on seoses sellega oluline rõhutada, et Wittrami näite põhjal tuleb revideerida historismiuurimises aastaist 1992/94 päris üldiseks kujunenud seisukohta, mille järgi kogu "historismi probleem" (väärtuste relativism, ajaloo suhe eluga, ajaloo piirid teadusena) kui probleem - 1920. aastateni saksa teaduskultuuris diskussiooni objekt - kaotati silmist "alates 1933" uues "poliitilises kontekstis". ${ }^{53}$ Wittrami tekstid aastaist 1936/38, nagu ka tema "Ajalookäsitus ja tõeküsimus" (1946/47), mis jätkab sõjaeelseid probleemiarutlusi, kinnitavad, et see (Baltikumi kui Euroopa "perifeeriat" ideede ajaloos välistav?) seisukoht pole teaduslikult õige ega saa kehtida üldisena.

50 Wittram, R. Die geistige Lage des baltischen Deutschtums in historischer Perspektive, 260.

Wittram, R. Toleranz? Zur Klarstellung. - BMH, 1933, 2, 116.

Wittram, R. Die Generation von 1919, 11.

See idee, olles seotud ka Karl Heussi "Historismi kriisi" (1932) ja Friedrich Meinecke "Historismi tekkimise" (1936) kriitikaga, läbib nt Annette Wittkau kõrgel analüüsitasemel kirjutatud monograafiat, vt Wittkau, A. Historismus. Zur Geschichte des Begriffs und des Problems. Göttingen, Vandenhoeck \& Ruprecht, 1992 (2. trükk: 1994). Paraku on selle korraliku töö puuduseks, et autori vaateväljast on jäänud peale Croce kõrvale ka Wittram ja tema kriitika "Meinecke historismi" aadressil. 
Wittrami probleeminägemise kohta, mida siinkohal üksikasjalikult ei arutata, tuleb eelkõige ära märkida järgmist. Historismis tegi Wittram 1930.-40. aastail vahet selle traditsionalistlikul (positivistlikul) ja relativistlikul aspektil või faasil, ning selles vahetegemises on selgelt tajutav 2. "ajakohatu vaatluse" Nietzsche juuresolek. Olgugi et nimeliselt mainitakse Nietzschet koos oma 1870. aastate traktaadiga "Ajaloo kasust ja kahjust elule" Wittrami artiklites vaid mõni kord, tehakse seda just põhimõttelise või programmilise iseloomuga tekstides, millest kindlasti tähtsaim on 1930. aastate lõpu "Historism ja ajalooteadvus". Viimane on mõnes mõttes Wittrami "dualistliku ajaloovaate" kvintessents: peale rahvussotsialistliku ambitsiooni, mis iseloomustab tema käsitluslaadi Zeitwende aspektist, sisaldab see historismianalüüs ka "ajaloolise väärtustusviisi pingete" erilist taju. Baltikumi regionaalses ajalookultuuris - sõltumata sellest, kuidas ta asja (rahvus)ideoloogiliselt lahendas - on Wittram peale saavutuste ajalookirjutuse vallas ka historismi probleemi arhitekt. Selle aegu ületava probleemi teadvustamise ja kaardistamise tõttu on Wittram - kui soovite: paradoksselt - rohkem meie kaasaega küündiv ajaloolane kui mõni teine, kelle poliitilisele minevikule ei saa natsismi suubunud natsionalismi omistada. Asjaolu, et tema historismikäsituse senisel mittemõistmisel on regionalismist kaugemale ulatuvad järelmid, näitab Wittrami väär samastamine "positivistliku historismiga" ja tema niisama väär vastandamine Martin Heideggerile ning "heideggerlikule ajaloomõistmisele" ühe XX sajandi teise poole tuntuima protestantliku teoloogialoolase poolt alates 1960. aastate lõpust. $^{54}$

Kriitika "XIX sajandi konserveerimise" vastu balti ajaloomõtlemises kannab Wittram laiahaardeliselt ja analüütiliselt ette kõigepealt detsembris 1934 historistliku traditsionalismi kehastuse - Riia Ajaloo ja Muinasteaduse Seltsi - 100. aastapäeva pühitsusel. ${ }^{55}$ "Võib-olla suurim oht, mis meid tänasel päeval ähvardab, on historismi taaselustumine - formaalsete traditsioonide jätkamine ilma selle ülekontrollita, mille paneb meile peale tegelikkus ja milleks meid sunnib meie ajalooteadvus. Eelkõige me vajame uuesti suurt pilku asjadele, pilku, mis ei hõlma varasemaid sajandeid üksnes uurimisobjektina, vaid haarab nad tähendusseosesse, mis alles hakkab meie aimdusele avanema. Vajame ajaloovaatlust, mis kujutab

54 Vt Zahrnt, H. Die Sache mit Gott. Die protestantische Theologie im 20. Jahrhundert. München, R. Piper \& Co. Verlag, 1967, 287. - Väljend “alatest 1960. aastate lõpust” on õigustatud sellega, et Heinz Zahrnt ei ole raamatu uustrükkides seda tekstikohta, mis tal paikneb Bultmanni Heideggerimõjuliste vaadete kontekstis, korrigeerinud (nt teose 1988. aasta 8. trükk [Serie Piper, 890] esitab selle muutmata kujul). Eksitav on autori väide kontekstuaalseski mõttes: Wittramil oli juba 1960. aastate esimesel poolel teatav - ütleksin: "mõtteline" - kontakt Heideggeri-sfääriga, nt ta jälgis H. Arendti esinemisi, R. Bultmanni puudutavat, suhtles isiklikult H.-G. Gadameriga (Gadamer on muide esile tõstnud Wittrami hermeneutilist ajaloolise tõe käsitust). Kontaktil on olemas veel teine, "poleemiline" külg: 1950. aastate lõpul on Wittram arutlenud ka Heideggeri metafüüsika-ajaloo kontseptsiooni sobivuse üle maailmaajalooliste muutuste seletamisel. Oletan, et selle kontakti iseloomu kohta võib täpsemat teavet anda Wittrami arhiveeritud, kuid publitseerimata kirjavahetus, aga ka tema eluajal avaldatu põhjal ei saa aktsepteerida Zahrnti vastandusi.

55 Vt Wittram, R. Geschichtsbewusstsein und Geschichtsbetrachtung im baltischen Deutschtum, 9 ja 1. 
meile kõiki verepäraseid-rahvapäraseid protsesse ega jäta tähelepanuta hingejõudude salapärast toimimist." Põhiline selles - rahvussotsialismi eelsugemetega - esituses on ära öeldud kohe alguses: "kaasaegse elutunde sõltuvus eelnenud arenguga oleva seose tõsikindlusest ja vajadus teatud õigustuse järele selle peeglis" on see historismi-kultuuri "loomujoon", mis Wittramil edaspidi "uute küsimuste tulvavas rohkuses" lähebki vaidlustamisele. Küllalt moodne on selle (vastu)kriitika näitel ka ettekujutus ajalooteadvuse struktuurist. Historistliku kultuuri kritiseerimises mängib Wittramil kaasa oma tegevusmõtte otsing, "suur pilk" on ajalooteadvus, kus minevik ei valitse oleviku üle ja laseb sisse tuleviku. Ajaloolise hariduse (kui "kodanliku hariduskaanoni tuuma") ${ }^{56}$ formaalne iseloom teda seepärast - nagu varem Nietzschet - ei rahulda. Ometi on Wittram ise traditsiooni (või kaanoni) kriitikuna juba niivõrd traditsiooni osistest laetud ja täidetud, et väljaastumine, mida alustatakse Nietzsche tähe all, lõpetatakse ikka Rankega: "oleviku karmis võitluses" saab leida rahustust "tõsikindluses, mis sellisele mehele nagu Ranke avas lihtsa tõe, et epohhide vahetuses ja konfliktis on kogu ajalugu suhtes Jumalaga". Wittram pole siin vastutamatu retoorik, kes nagu ei teaks, mida õieti räägib. Klassikalise historismi "ajalooreligiooni," historismi elemendid, saadavad Wittramit kogu elu. Alles 1963. aastal, kui tema "historism" on ajakogemuse tõlgendusena juba kriitiline ajaloohermeneutika, leiab ta oma mõtetes teadusliku "meetodi" ja asjaõige "interpretatsiooni" kooskõlaks (Rudolf Bultmanniga seoses) "dialektilise historismi" sobiva vormeli: "kõik, mis meid olemusparatamatult puudutab, [...] on ligipääsetav niihästi objektiveerivale vaatlusele kui eksistentsilisele kogemusele..." ${ }^{58}$ Dialektika pole selles seoses marksistlik nugisõna, ${ }^{59}$ 1960. aastate mõistetarvitusest juurdub Wittramil midagi 1930. aastate äratundmistes. "Historismi ajastu", mille tendentse ta arvustas, olevat

56 Vt Mommsen, W. J. Der Historismus als Weltanschauung des aufsteigenden Bürgertums, 393.

57 Ajalooreligiooni mõiste kohta, millega peetakse silmas saksa historismi "ajalooteoloogilisi eeldusi" (nt Rankel) ja üksikautorite ajaloomõtlemise "religioosset läbivormitust" (W. v. Humboldtist kuni F. Meineckeni), vt eelkõige Wolfgang Hardtwigi artiklit: Hardtwig, W. Geschichtsreligion - Wissenschaft als Arbeit - Objektivität. Der Historismus in neuer Sicht. - Historische Zeitschrift [edaspidi: HZ], 1991, 252, 1-32. - Wittrami suhe Ranke ajalooreligiooniga, mille jätkajaks võib osalt pidada ka veel Troeltschi, ei mahu käesoleva käsitluse raamesse; selle suhte ajaloofilosoofiline probleemsus tuleneb/järgneb ennekõike Wittrami Nietzsche-konteksti vaatlusest. Wittrami Ranke-teesid kuuluvad ühelt poolt tema heitlusse "metafüüsikaga" historismis ja seega historismikriisi struktuuri, aga teiselt poolt ka (nõukogulik-parteilise) marksismi ajaloosotsioloogia ja teadusmoraali kriitikasse, mida Wittram arendas. Seetõttu vajab probleem omaette käsitlust.

58 Wittram, R. (Buchbesprechung.) Die Frage nach dem historischen Jesus und die Ontologie der Geschichte. Von Heinrich Ott. Zürich, EVZ-Verlag, 1960. - HZ, 1963, 196, 364.

59 Dialektilise historismi mõistet kasutas teistsuguses, marksistlik-ideoloogilises tähenduses nõukogude filosoof Valentin Asmus (1894-1975) oma esmalt 1933 ja uuesti 1971 ilmunud teose "Marx ja kodanlik historism" kontseptsioonis, vt Asmus, V. F. Marks i burzhuaznõi istorizm. Id., Izbrannyje filosofskije trudy, t. II. Moskva, Izdadel'stvo moskovskogo universiteta, 1971, 205-429 ja 437-443. Asmuse kriitikat vt leedu autori Zenonas Norkuse vene historismi käsitleva töö lõpuosas: Norkus, Z. Historismus und Historik in Russland (1865-1933). - Historismus in den Kulturwissenschaften. Geschichtskonzepte, historische Einschätzungen, Grundlagenprobleme. Hrsg. von O. G. Oexle und J. Rüsen. (Beiträge zur Geschichtskultur, 12.) Köln, Weimar, Wien, Böhlau Verlag, 1996, 369-386, siin 385 jj. 
ühtlasi andnud võimaluse näha "ajaloolise protsessi dialektikat" - tema mõistes midagi sellist nagu ajaloolisuse paradoksaalsust, kuna ajaloo kulus sisaldub vastuolulisus ("igavene paradoksia"), mitte harmoonia: "Ajalugu kui draama - ainult nii vaadates paljastab ta oma tegeliku näo." ${ }^{, 60}$ Faktiliselt sama idee oma plastilise lühidusega on hiljem korduvalt telg, mille ümber liiguvad Wittrami mõtted. Nõnda ka 1964. aastal vastusena päritolu-küsimusele ilmunud essee "Pärand ja ajalugu" mõtisklustes baltisaksa ajaloolise identiteedi üle, kust joonistub välja samuti tema isiklik XX sajand: "Ajalookäsitus, mis tahtis püüda orienteeruda 'normaalsele arengule', näis meile ajaloo olemust mitte tabavat. [...] Tema (ajaloo) tõde on kestvuse ja muutuvuse paradoksia." ${ }^{61}$

Põhijoontes on Wittramile historismisse diferentseeriva suhtumise vajadus olnud selge tema teaduskarjääri algetappidest peale, seda kinnitab oktoobris 1937 Riia Herderi-Instituudi 10. aastapäeva ettekandes "ajaloomõistmise põhiküsimuste" kohta väljaöeldu: "Nagu kõik abstraktsed mõisted, nii peegeldab ka sõna "historism" väga erilaadset. [...] See nimetus märgib - laitvas või tunnustavas mõttes - suhet ajalukku [ein Verhältnis zur Geschichte], mis põhiliselt hõlmab järgmist: see on pöördumine möödunu poole kaasaegsest elust ärapööratuse mõttes ja mineviku muutmine lõputult relativeerituks, alalõpmata uuesti [ständig neu] relativeeruvaks individuaalnähtuste liikumistervikuks." ${ }^{62}$ Historismi kui ajaloosuhte kahetähenduslikkuse toob Wittram esile täiesti nietzschelikult. Nietzsche esitab oma mõtte geniaalselt, kujundiga lapsest, kes õpib sõnast “oli" ( "es war”) aru saades - meenutades - mõistma, "mis tema [st inimese] olemasolu põhilises on - üks ei iialgi lõpule jõudev imperfektum" (HL 1). Protest XIX sajandi "ajaloovagaduse elutunde" vastu on Wittramil seda suurem, mida enam see "kultuuriloolise vaatlusviisi" kehtestumisel hakkab "rahvasteelu poliitilist närvi" varjama ja unustab "tähtsaima": "et kultuur peab olema rohkem aretus [Zucht] kui vaim [Geist], suutmaks jääda loovaks". ${ }^{33}$ Objektiivsust hindav teadlane hakkab siin poliitikule järele andma rohkem kui vaja, hoolimata sellest, et Wittrami muudes sama perioodi tekstides on rõhutatud "vaimse diktatuuri" mitteaktsepteerimist.

60 Wittram, R. Historismus und Geschichtsbewusstsein. - BMH, 1937, 10, 558.

61 Wittram, R. Das Erbe und die Geschichte. - Baltisches Erbe. Fünfundsechzig Beiträge in Berichten und Selbstzeugnissen. Hrsg. von E. Thomson. Frankfurt a. M., Wolfgang Weidlich, 1964, 137. (Eesti keeles: Wittram, R. Pärand ja ajalugu. [Tlk M. Kivimäe.] - Sirp, 1993, 16. aprill.)

62 Wittram, R. Historismus und Geschichtsbewusstsein, 553. - "Historismi"-ettekande ümbertrükk ilmus - kõrvuti Erich Seebergi ulatusliku retsensiooniga Meinecke "Historismi tekkimisele" - ka Saksamaal Historische Zeitschrift' is: vt HZ, 1938, 157, 229-240. On märkimisväärne, et Seeberg - nagu Wittramgi - ei samasta historismi enam "positivistliku artistikaga", vaid ütleb, et "jääb relativism historismi probleemi kui sellisena" [als d a s Problem des Historismus]; seda "relativismi ehk "väärtuste anarhiat"” ei saavat "ületada" vaimuteaduslikult, küll aga "sõda ja kaotust, varingut ja tõusu" kogenud generatsiooni "uute jõududega" - uue jõulise "poliitikaga", "elutahtega": "Võib-olla see pole enam "historism'; aga see on ometi elamine ajaloost. Sest meieeelne põlvkond üritas oma elu mõista ajaloost lähtudes; meie tahame ajalugu seletada, vallata ning viljakaks teha oma elust lähtudes.” (Seeberg, E. Zur Entstehung des Historismus. Gedanken zu Friedrich Meineckes jüngstem Werk. - HZ, 1938, 157, 264 jj, tsitaat 265.)

63 Wittram, R. Historismus und Geschichtsbewusstsein, 555. 
Historismi probleemi käsitlemine on just see sfäär, mis näitab meile, esiteks, et Wittrami ajaloovaatlus - 1930. aastail üha tähtsustuva poliitilise elemendiga on samal ajal tema kultuurikriitika; ja teiseks, et see kultuurikriitika on - kui nii võib öelda - Wittrami enda rahvussotsialismi teoreetiline raamistus. Relativistliku historismi tunnetus ei mobiliseeri teda ainuüksi traditsioonilise historismi kriitikaks, vaid ka poliitilisteks abinõudeks, et relativismi ohjeldada. Olemismure, mis Wittramit ajaloolase, ideoloogi ja poliitikuna maha ei jäta, paistab olevat ehtne seda tuleks ehk öelda kolmandaks, sest XX sajandi ajalugu tunneb poliitilisi aferiste, kelle tegevus ei ole nii väga seostatav metafüüsiliste ajenditega. Wittrami historismiarutluses on vaja, neljandaks, seoses rahvussotsialismi ideega, asetada rõhk liitsõna esimesele ja tema jaoks ajalooliselt tähenduslikumale osale, muidu käivitab mõni määratlus (näiteks: see on "grandioosne tervenduskatse", millel on "metafüüsiline õigustus") ${ }^{64}$ nüüdisajal väärade assotsiatsioonide ahela. Väljendit "natsionaalsotsialism" (kui parteipoliitilist definitsiooni) on Wittrami völkischsõna 'rahvusliku' tähenduses kasutavais artiklites - enne 1940-ndaid - välditud. Natsionalismi sulandamine sotsialismiga, nagu seda kujutas natsistlik-pööbellik propaganda, on sageli rahvuskultuurilise enesemääratluse pinnalt lähtuva Wittrami puhul raskesti usutav.

Ajaloo protsessuaalsel modelleerimisel eristab Wittram tavalisel moel kolme põhilist teooriat: regressiivse, progressiivse ning tsüklilise arengu teooriat. Neid eristades peab ta viimast - ajaloolise ringkäigu teooriat - teistest küll "sügavamaks", kuid samas nendib, et ehkki tema kaasaegne historism oma "Iõputu vooluse kaemusega" (Anschauung des unendlichen Fliessens) on kõik need teooriad sisuliselt "võimatuks teinud", pole sellega "igasugune sihipüüdlikkus" veel kadunud. "Uus on massipäraste [massentümlicher] nähtuste planetaarne levik, uus on tehnilise loodusevalitsemise võrdlemisi erakordne aste ja uus on ennekõike kõigi ürgloomulike [urtümlichen] usuhoiakute lagundamine selle ratio poolt, mille nihilistlikus demoonias kõik euroopa kriitika vaimud elavad kõigist sidemetest lahti päästetud, vallandunud ja kuni viimse hingekiuni viljatut elu. See psühholoogiline tõsiasi on võib-olla maailmasituatsiooni kõige üldisem tunnus. Kui inimese sisemus on hävitatud, saab inimesest tuumata kest, riidest nukk, millega huvid mängivad oma mängu. Aga sellega lakkab olemast ka see, mida tavatseme nimetada ajalooks. Kui kõik allutatakse psühholoogilisele tehnikale, hukkub [geht zugrunde] loov substants, ja väärtustemaailma, mis on meie jaoks ainsana ajalooline maailm, asendab too varemete, betooni ja raua metsik kaos, nagu selle jätab tavaliselt maha moodne vabrikupõleng." ${ }^{\circ 5}$ Olulisim on siin tähele panna, et Wittram vastandab XIX sajandi kaemuslikule historismile, mida tema ajal püüdis saksa ideeajalookirjutuses rekonstrueerida Meinecke, ajaloo tegevusliku iseloomu, mis tema nägemuses vastab "uuele" - XX sajandi ülesannetele, muutunud olukorrale, konkreetsele ajahetkele. “... Tegutseja [der Handelnde] on teadlik situatsiooni teravast ainukordsusest, silmapilgu otsustamise-iseloomust, sündmustiku [des Geschehens] dramaatilisest punktist. Tegevus on draama olemus, ja võitlus on tegevuse ole-

64 Wittram, R. Historismus und Geschichtsbewusstsein, 558.

65 Samas, 557-558. 
mus. ${ }^{, 66}$ Ka vastab see Wittrami kaemusliku-tegevusliku opositsioon Nietzsche 2. "ajakohatu" vastandusele (Zuschauer-Handelnder) (HL 3; 5), mis kuulub tema historismikriitika püsimotiivide hulka. Nietzschel alatihti sõlmuva mõtteseose järgi olevat kaemusliku historismi kultuur elule "kahjulik ja ohtlik", sest ta toodab "nõrgestatud isiksusega" moodsat inimest, kelle instinktiivne elu- ja teojõud, ümber loov või kujundav võime, on ajalooalasest epigonismist "halvatud" (gelähmt) (HL 5). Nietzsche kui kriitikuga võrreldes on Wittramile oluline baltlaslik kohustatuse moment. Wittramil, kes samuti kritiseeris epigoonlikke jooni baltisaksluses, on peamine siht päästa nn rahvusvõitleja etapilise malli järgi ("1905, 1919 või 1933") konstrueeritud "tugeva isiksuse" moel orientiire andva poliitilise teoga oma kogukond ajaloolisest kriisist.

Historismi, regionalismi ja ka globalismi ideekompleksist kasvab Wittramil välja aktsionistlik käsitus ajaloost, mille olemuse moodustab võitlus väärtuste pärast. Selle aktsionismi üks teoreetiline, kontseptuaalne allikas on Nietzsche elufilosoofiline historismikriitika koos Troeltschi "eksistentsilise historismiga", nagu seda nimetasid omal ajal viimase kaasaegsed. Seda 1930. aastate, mõneti eksistentsialistlike joontega aktsionismi võiks iseloomustada Wittrami "historismi ületamise" katsena, millest ta hiljem, 1950. aastail loobus, märkides seejuures, et "historismist pääsemist" ei ole. Põhjused, miks ta seda tegi, olid nii poliitilised ja moraalsed kui ka ajalooteoreetilist laadi. Relativismi taandamist metafüüsilise suurusena käsitatud rahvusprintsiibi abil, mis tõi kaasa poliitilise julmuse ja riikliku autoritarismi, ei saanud lugeda historismi probleemi lahenduseks kultuuris. Wittrami enda 1970. aastate alguse tagasivaatelisel kõnelemisel "eksistentsikriisist", ${ }^{67}$ tuleb arvata, on küllap võrdselt kaasa mänginud nii elupraktiline kui teadusteoreetiline aspekt.

\section{NIETZSCHE-JÄRGSE WITTRAMI ASTMED Totaalne historism ja poliitiline ajalugu}

Õigustatud on küsimus, milline on Wittrami ja tema rahvusluse suhe sellega, mida võiks nimetada rahvussotsialistlikuks "nietzscheanismiks". Küsimusele pole aga praeguses uurimisstaadiumis, kaasamata analüüsiks ideoloogialoolist lisamaterjali, minu arvates võimalik korralikult vastata. Ometigi on võimalik visandada mõningaid kontuure, nende puuduseks on küll üldjoonelisus, ent vooruseks on see, et nende abil saab ära hoida spekulatiivsuse käsitluses, nagu ka ebaproportsionaalsuse hinnangus. Wittrami legendaarse "natsiseotuse" tõttu näib olevat mõnede kontuuride tõmbamine täiesti asjakohane ka selleks, et muuta seotusepind reljeefsemaks, sest olles näiteks seotud nn Rosenbergi Ametiga, ei saa teda

66 Samas, 559.

67 Pistohlkors, G. v. Baltimaade regionaalne uurimine Saksamaa Liitvabariigis. Ülevaade 1980. aastate lõpul. [Tlk S. Kivimäe.] - 50 aastat Eesti Teaduste Akadeemiat (Teaduslugu ja nüüdisaeg). Koost K. Martinson. Tallinn, Eesti Teaduste Akadeemia, 1989 [õieti: 1990], 212. (Algselt ettekanne Eesti NSV TA Presiidiumis Tallinnas 26. septembril 1988.) 
pidada kohe osaliseks Alfred Rosenbergi Nietzsche-eklektikas, mis vaatab meile vastu natsirežiimi fassaadilt. Käesoleva artikli lõpus puudutan ma seda küsimust veel kord autentsusprobleemi vaatevinklist, pidades silmas, kuidas võiks iseloomustada Nietzsche-kontakti kaudu, mida dokumenteerivad tekstid, Wittrami kui ajaloolase omanäolisust.

Ajaloolasena promoveerunud Wittrami esiletõusu ajaks kriitilise publitsistina (1926/28-1934 oli ta vastavalt baltisaksluse aastaraamatu ja kuukirja toimetaja) oli "emamaal" toimunud või toimumas Nietzsche tööde rahvuslik omastamine poliitilise ja kasvatusliku tarbimise mõttes. Kuigi sel ajal käibis erinevaid Nietzschepilte (nagu praegugi) ja säilis teatav pluralism, sai Nietzschest "heroilise realismi" maailmapildi ametlik kandja. Nietzschet ei esitletud mitte ainult suure herakleitosliku mõtlejana, kes "heroilisest ajalookäsitusest lähtudes" oli tegelnud "historismi probleemiga", ${ }^{68}$ vaid kogu ofitsiaalse rahvuspoliitilise filosoofia (nn völkischpolitische Philosophie) juhtkujuna Saksamaal. "Suure Brockhausi” täiendusköide, natsismi maailmavaatele kohandatud infopank, ütleb 1935. aastal Nietzsche kui "1933. aasta murrangust saadik eriliselt tunnustatud" filosoofi ja võitleja kohta, et ta olevat ka une Juhiriigi vaimne kaasrajaja: "Kolmas Riik kehtib paljudele tema teoreetiliste ning kõlbeliste ideaalide täideminekuna [als Erfüllung]." ${ }^{69}$ Nagu teada, külastas Hitler 1934. aastal isiklikult Nietzsche vanurist õde Weimaris ja laskis selle riikliku austusavalduse jäädvustada oma propaganda huvides. Kõik ei taandu sellises retseptsioonis aga puhtpoliitilisele ärakasutamisele, Nietzschel oli ja on sakslastele rahvuslikku külgetõmmet. Seda tajus samal perioodil - Wittrami esiletõusuga Baltikumis samaaegselt - Nietzsche-uurijate esiritta kerkinud Löwith (juba paguluses) 1940. aastal: "Anglosaksi maailm, isegi Itaalia ja Prantsusmaa koos d'Annunzio ja Gide'iga - nemad ei suuda seda iial täiesti mõista, nii võõras on neile olemuselt see, mis sakslasi Nietzsche juures ligi tõmbab. Ta on nagu Luther eriomaselt saksalik sündmus [ein spezifisch deutsches Ereignis], radikaalne ja saatuslik." ${ }^{, 70}$ Heroism

68 Vt nt Nietzsche esinemissagedust ja ta isikuartiklit Heinrich Schmidti surma (1935) järel rahvussotsialistlikuks ümber töötatud "Kröneri" filosoofialeksikonis: Philosophisches Wörterbuch. Begründet von H. Schmidt. 10. Aufl., völlig neu bearb. von W. Schingnitz und J. Schondorff. Stuttgart, Alfred Kröner Verlag, 1943, 407-411 (siin 408); 652 jj. - Selle Nietzsche-pildi autoriteedid olid Alfred Baeumler ja Heinrich Härtle.

Der Grosse Brockhaus. Handbuch des Wissens in zwanzig Bänden. 15., völlig neu bearb. Aufl. Ergänzungsband 21 (A-Z). Leipzig, F. A. Brockhaus, 1935, 582.

70 Löwith, K. Mein Leben in Deutschland vor und nach 1933. Ein Bericht. Mit einer Vorbemerkung von R. Koselleck und einer Nachbemerkung von A. Löwith. Frankfurt a. M., Fischer Taschenbuch Verlag, 1989, 6. - Löwith on samas ("Nietzsche enne ja pärast Hitlerit") (5) tunnistanud, et tedagi nakatasid varem samad "ohtliku elamise" mõtted, mis viisid "paljudel kaudteil ja ometi otseteed Nietzschest Goebbelsi heroiliste fraasideni". Goebbelsi fraas, millele Löwith viitab (“... meie [st natsipartei] oleme Nietzsche ütluse tõeks teinud: 'Olgu sul julgust ohtlikult elada!’”) (140), on Kanti üldtuntud valgustusdeviisi paroodia: kutse iseseisvale mõistusetarvitusele (tunnetuslikule autonoomiale) on asendatud poliitilise massipartei kutsega riskeerimisele. - Wittram oma publitsistikas just ei rõhuta (ehkki kasutab) heroismi-sõna, kuid tema seotus Löwithi poolt kirjeldatud kontekstiga näib olevat vaieldamatu. 1933. aasta esimesel poolel ei piirdu ta tavalise, "Vana-Liivimaa kolonisaatorit" ja moodsate aegade "baltlast" ühendava "võitluse" retoorikaga (vt nt Wittram, R. Deutsch und baltisch. Zum Verständnis der deutschbaltischen politischen Tradition. - BMH, 1933, 4, 198), vaid kõneleb “eluohtlikus võitluses” olemisest. 
koos poliitilise keele rassilis-võitlusliku paatose ja sinna juurde käivate mantratega $^{71}$ - sellesse Nietzsche-konteksti paneks meie teema puhul Wittrami "kominternliku" fašismimõiste (nt Eestis veel 1987. aastal järgitud) ${ }^{72}$ traditsioone jätkav lähiajaloolane. Kuid ta paneks Wittrami sellesse konteksti üleni ja täielikult, vähimategi omapära-mööndusteta, tehes endale tema juhtumi kritiseerimise (üldjuhtumi tunnuste põhjal ja konteksti kuulumise pärast) enam kui lihtsaks. ${ }^{73}$

Nüüdisajal (15 aastat hiljem) võib vähemalt historiograafilises mõttes tunduda kummastav, et veel 1989. aastal sai meie poliitilises süsteemis Gorbatšovi perestroika "uue poliitilise mõtlemise" fraaside toel liigitada baltisaksa tippajaloolasi (Wittramit, Rauchi jt) endistviisi "Nõukogude-vastasteks" "Ida-uurijateks". ${ }^{74}$ Võib

71 Heroismi mõiste kohta "natsismi keeles" on siiani üks paremaid eritlusi Victor Klempereri sissejuhatus oma kuulsale raamatule (kahetsusväärselt andis see hitlerismi-analüütik pärast seda oma osa stalinismi kujutamisse "humanismina"): Klemperer, V. LTI. Notizbuch eines Philologen (1947). 8. Aufl. Leipzig, Verlag Philipp Reclam jun., 1985, 7-14.

72 Vt. artikkel "fašism": Eesti Nõukogude Entsüklopeedia, 2. Tallinn, Valgus, 1987, 670; vrd seevastu klassikalist tööd fašismi-uurimise alalt: Nolte, E. Der Faschismus in seiner Epoche. Action francaise - Italienischer Faschismus - Nationalsozialismus [1963]. Mit einem Rückblick nach fünfunddreissig Jahren [1999]. 5. Aufl. München/Zürich, Piper, 2000; vt ka põhimõttelise tähtsusega diskussiooniartiklit: Nolte, E. Einige abschliessende Bemerkungen zum Begriff des Faschismus (1978). - Ders., Was ist bürgerlich? und andere Artikel, Abhandlungen, Auseinandersetzungen. Stuttgart, Klett-Cotta, 1979, 134-153. - ENE 1. trükk (1968-78) Wittrami-nimelist teadlast ei tunne, EE 10. köite (1998) isikuartikkel Wittramist läheb tema tähendusest ajalooteadusele mööda. Nõukogude aja fraaside kohaselt oli Wittram "saksa fašistliku historiograafia" ja "baltisaksa mõisnike" esindaja, see tähendab: "Wittram" oli parteipoliitiline konstruktsioon. On aga täiesti ilmne, et tema teaduslike vaadete asjalikku käsitlemist Eesti NSV-s ei takistanud üksnes "valvsa silma" kohalolek teadusasutustes ja nõukogulik välispoliitika (et Wittram oli nõukogude "organite" huviorbiidis ka 1943 talle Eestist Poolasse saadetud arhivaalide "tagastamise" küsimuses, tõendab Indrek Jürjo poolt leitud salajane kirjavahetus Tallinna ja Moskva vahel 1956/57). Wittrami käsitlemiseks ei pakkunud eeldusi ka "formatsiooni-marksism" ja (paljudele sunnitud) kohandumine selle puhtalt ajaloopoliitiliseks võimukeeleks muudetud ajaloo-ontoloogiaga, millele tegelikult polnud olemas (nüüdisajaloos keskseks muutunud) individuaalse ajaloolise kogemuse probleemi. Wittram uuris seda probleemi nt oma Peeter I-le pühendatud kahes raamatus (nn väikeses [1954] ja suures [1964] "Peetris") ja mitmetes artiklites; eesti ajaloolased, kelle erilist tähelepanu need - ja muudki - Venemaa-ainelised biograafilised saavutused ei pälvinud, võtsid reeglina sõna tema "Balti ajaloo" üldkäsitluse asjus. Wittram on lasknud aimata, et tema huvi inimese vastu ajaloos võib olla seotud juba Halleri õpetustega (vrd Wittram, R. Professor D. Dr. h. c. Dr. Johannes Haller zum siebzigsten Geburtstag. - BMH, 1935, 10, 584-586).

73 Programmiline parteipoliitiline keel, mida üht aega käsitlev ajaloolane ei tohiks - selle keele semantika uurimise asemel - ise hakata ekstaatiliselt rääkima, on tihti kõrgelennuline (õhutav, ründav ja värbav) ning oma poliitilise identiteedi keskne. II maailmasõja järgselt, nt 1951. aasta Sotsialistliku Internatsionaali demokraatliku sotsialismi teesides, kus öeldi, et nüüdiskapitalism on "teravdanud rahvuste ja rasside konflikte" analoogiliselt "mineviku barbaarsusega" (fašismi ja natsismiga), esitati ka "rahvusvahelise kommunismi" kui "uue imperialismi tööriista" selline kirjeldus (10. tees), mille paatosele avaldanuks sümpaatiat nii mõnigi rahvussotsialist (vt Weber, $\mathbf{H}$. Das Prinzip Links. Beiträge zur Diskussion des demokratischen Sozialismus in Deutschland 1848-1990. Eine Dokumentation. Berlin, Ch. Links Verlag, 1992, 218-220).

74 Näide on võetud 1988. aasta aprillis trükkida antud teosest (Mattisen, E. Tartu rahu. Monograafia. 2. trükk. Tallinn, Eesti Raamat, 1989, 57 jj), mille eessõnas (12) on autor tunnistanud endale siduvaks teadusliku objektiivsuse kõrge astme (huvitumatus "ühegi aspekti mahavaikimisest või moonutamisest"), suutmata - historiograafilise aspekti propagandistlikus käsitluses nõuet järgida. 
olla peaaegu kindel, et nõukogude perioodi Baltikumis ei teadvustanud ajaloolise professiooni eest vastutavad akadeemilised isikud ${ }^{75}$ - nii kaasalööjad kui kohandujad - seda fakti, et Wittram kuulub ajalooteaduse maailmaajalukku ("Herodotosest Foucault'ni"). See kummastus, et demokratiseerimise maneeris saab ajalookirjutaja edukalt praktiseerida neostalinismi terminoloogiat, tähendab aga seda, et režiimisõltelise ajaloolase keel, mis on loomulikult niisama vähe erapooletu nagu ideoloogiakeel üldse, on teatud osas ka poliitiliselt sümbiootiline - selles "elavad koos" väga erilaadsed kihistused, mitte sugugi üheselt võetavad komponendid. Näiteks on varase Wittrami formuleeringute puhul analoogilisi probleeme, mida ma nimetaksin teisendkeele probleemideks, sest eesti keeles on "teisend" sama asja 'teisiti esinev kuju'. Leksikaalne usk, kui kasutada Michael Garleffi väljendeid, võib tekstihindaja "eksiteele viia" (verleiten) ja nõuab "täpsemat analüüsi". Garleff on Rauchi kurikuulsa pealkirjaga Blut und Boden-artikli vaatluses tõestanud, et selle 1936. aasta teksti "tiitelformuleeringust" hoolimata pole tegemist natsistliku propagandakirjanduse tootega ${ }^{76}$ Germaani õigusest natsipoliitika keelde toodud ideologeemi tarvitus ei vasta baltlasel doktriini standarditele. Niisamuti nagu Rauch on Wittram selleks liiga väljapaistev, kaaluka teadusloomega ajaloo-

75 Siin tuleb märkida, et akadeemik Juhan Kahki (1928-1998) "dialoog R. Wittramiga" on ideoloogiline müüt, mis on jäänud tänase päevani meie teadusliku ajalookirjanduse osaks ja mida kaldutakse vaatlema nn Kahki positsioonilt, mitte "teisest" - Wittramist - lähtudes (vt nt Karjahärm, T. Ajaloolase käsiraamat. Tallinn, Argo, 2004, 137; vrd Kahki "poleemika" kohta Wittramiga ka: Rosenberg, T. Juhan Kahk agraarajaloolasena. - Ajalooline Ajakiri, 1998, 4 (103), 58). Ka ei tuleks seda "dialoogi" - mis on dialoogipärane vaid formaalses-temaatilises tähenduses - dateerida 1978. aastaga, mil Kahk laskis selle väljendi nõnda ära trükkida, vaid vähemalt ajavahemikuga 1969-86, kui mitte alates 1961. aastast, mil Kahk hakkas aktiivselt osa võtma "ajalooteaduse alal peetavast ideoloogilisest võitlusest" (vrd Kahk, J. Lääne-Saksa reaktsioonilised ajaloolased Bonni militaristide teenistuses. - Kaasaja ajaloost. Lühiartiklite kogumik. Toim J. Kahk ja P. Larin. Tallinn, Eesti Riiklik Kirjastus, 1961, 32-47; tsit toimetajate saatesõnast, 6). Dialoogilisus ei ole üldse Kahki klassivõimu ja parteisuuniseid järgiva, printsiibilt "vaenutseva" ajaloosuhte olemuslik mõõde, ka mitte tema monograafiates talurahva-ajaloo alalt. Liialdatud poliitiline teenistusvalmidus iseloomustab Kahki ajaloopublitsistikat, mis oma teadusliku skematismi juures on kirjanduslikult sõnaosav, Eesti NSV lõpuni. Mitmekülgse, andeka ajaloolasena huvitus Kahk hilise Wittrami "ajaloofilosoofilistest" vaadetest, see on õige, ent ta ei saanud neist aru ja interpreteeris Wittrami võtmemõisteid vääralt (osalt takistas teda tõlgendamisel poliitilis-parteiline innukus - konformism -, osalt ta enda puudulik kontseptsioon ajaloolise teksti loomusest - "tekstuurist" -, osalt ideoloogiline uljus koos tollal ja veel nüüdki sellega tihti kaasneva võimetusega süüvida "teise sõna" semantilistesse maailmadesse). Oma nõukogudeaegsete rahvusvaheliste sidemete kaudu indutseeris Kahk eelkõige motiiviloolisi väärtõlgendusi Wittrami ajaloolisest mõtlemisest (nt selle mõtlemise kandvast struktuurist - ajametafoorikast) ka muudesse tolleaegse "sotsialismileeri" historiograafiatesse, kus neid kontrollimatult (algallikat "unustades") reprodutseeriti. Kahki "dialoog" Wittramiga saab praegu kehtida ainult "nurjunud dialoogi" kriitilises tähenduses, selle meie lähimineviku historiograafilise mõttestiili aspektidele valgust heitva "mittemõistmise" analüüsi (algselt - Ajaloo Instituudi tellimusel - 1993/94 tehtud, ent siis käsikirja jäänud) täiendatud variandi esitan ühes teises artiklis.

76 Vt nt Garleff, M. Georg von Rauch über die interethnischen Beziehungen in der baltischen Region. Zu seiner Geschichtsschreibung der Jahre 1935 bis 1943. - Zwischen Konfrontation und Kompromiss. Hrsg. von M. Garleff. (Schriften des Bundesinstituts für ostdeutsche Kultur und Geschichte, 8.) München, R. Oldenbourg Verlag, 1995, 202 jj. 
lane, et rahulduda tema lihtsa "paikapanemisega". Domineeriv on paraku viimane tegevus, selle kohta on näiteid mitte üksnes kommunistliku režiimi vajadustega seotud - Eesti ja Läti NSV või Saksa DV aegsest - retseptsiooniloost, vaid ka "ühetähenduslikele lõppjäreldustele" orienteeritud 1990. aastate uurimiskirjandusest.

(1) Minu teada on mõjukaist nüüdissaksa ajaloolastest üksainus - Wolfgang J. Mommsen 1978/1987. aastal - toonud Wittrami ta sõjajärgsete töödega (1958-66) positiivseks moraalseks näiteks teadlase võime kohta raskest poliitilisest minevikust õppida. Historismiteoreetilises plaanis näib Mommsen sellegipoolest oma sõnadega paljuski üle pakkuvat: "Wittrami tööd "Ajaloohuvi" ja "Tulevik ajaloos" juhatasid samuti radikaalselt relativistliku historismi revideerimise ning kogu poliitilise ja järelikult ka kogu ajaloolise mõtlemise üleajaloolist laadi kõlbelistele põhiväärtustele orienteerimise suunas."77 Selles hinnangus kõlab peale Wittrami isikuteema midagi vastu ajavaimust, niihästi 1970. aastate suunavõtust ajaloolisele sotsiaalteadusele kui ka Mommseni enda kuulsast väljendusest ajalooteaduse kohta "teispool historismi" (jenseits des Historismus). ${ }^{78}$ Et ajaloolased käsitasid historismi (individualiseeriva) meetodi probleemina, pidades sellist lähenemist sotsiaalsuse hõlvamisel vananenuks ja puudulikuks, minetati historismi tuumidee (väärtusrelativism), see, mille Wittram siiski alal hoidis. Seda fakti tuleb võtta nagu rõhu panekut: eksistentsialiseeriv suhe historismifenomeniga osutab nn varase ja hilise Wittrami ühtsusele, vaatamata tema ajaloolaseprofiili erinevustele enne ja pärast 1945. aastat, ka vaatamata oma rahvusluse pärastisele enesekriitikale. "Ajaloohuvi"-raamatus tsiteerib Wittram taas Nietzschet ja Troeltschi, ta solidariseerub ka viimase seisukohaga, et relativismi ja normativismi konflikt on "moodsa maailma eluprobleem". Oma kaasaegseist autoreist osundab ta seepeale fenomenoloog Landgrebet: "Tänapäeval (1957), tõsi küll," ütleb L[udwig] Landgrebe, "on see probleem üldisest teadvusest kadunud, ilma et ta filosoofilist lahendust leidnud oleks." ${ }^{, 79}$ Troeltsch nihkub tal nüüd veel rohkem esiplaanile kui Nietzsche, sest selle konflikti kogemuses peitub Troeltschi "teadusliku küsimuseseade algupära". Wittramile said tõepoolest väga tähtsaks kristliku metafüüsika mõisted, ent sellest hoolimata pani ta kirja - ajakohatult probleemiteadliku teesi: “Troeltschist saadik on õhus 'historismi ületamise' ütlus. Teiselt poolt on

77 Mommsen, W. J. Gegenwärtige Tendenzen in der Geschichtsschreibung der Bundesrepublik Deutschland. - Historismus und moderne Geschichtswissenschaft. Europa zwischen Revolution und Restauration 1797-1815. Hrsg. von K. O. Frhr. v. Aretin und G. A. Ritter. (Veröffentlichungen des Instituts für Europäische Geschichte Mainz. Beiheft, 21.) Stuttgart, Franz Steiner Verlag, 1987, 93. (Ettekanne 3. Saksa-Nõukogude ajaloolaste konverentsil Münchenis 13.-18. märtsil 1978.)

78 Konteksti kohta vt eelkõige Georg G. Iggersi töö 3. ptk ("Historismist 'ajaloolise sotsiaalteaduseni'”): Iggers, G. G. Neue Geschichtswissenschaft. Vom Historismus zur Historischen Sozialwissenschaft. Ein internationaler Vergleich. Mit Beiträgen von N. Baker und M. Frisch. München, Deutscher Taschenbuch Verlag, 1978, 97-156, eriti $130 \mathrm{jj}$.

79 Wittram, R. Das Interesse an der Geschichte. Zwölf Vorlesungen über Fragen des zeitgenössischen Geschichtsverständnisses. 2., durchges. Aufl. Göttingen, Vandenhoeck \& Ruprecht, 1963, 168. 
tunda, et see kogu meie eksistentsi määrav ajalooteadvus, mis on kätketud historismi mõistesse, on saanud nüüdiselu koostisosaks. Elu historiseerumise eelsete aegade juurde tagasipöördumine pole võimalik." ${ }^{, 0}$ Relativistlik historism tähendab Wittrami jaoks seda, et olemasolu jääb inimesele alati küsitavaks ja ajaloo mõistmine probleemseks, sama rõhutab ka püsitust maailmas, asjade voolavust, turvalisuse kaotust ("kõige kindla muutumine fluidseks", "kiire mööduvuse vastuvõtmine" jne) väljendav stiil. Wittrami historism on ajalooprofessori kohta isegi äärmuslik, sest see, mida ta tunnistab ja möönab ka kristlikule usule, pole muud kui totaalne ajaloolisus: "Ei ole olemas metafüüsikat ega immanentset ajalooloogikat, mis suudaks ületada ajaloolise relativismi." ${ }^{81}$ Võib-olla on tunnuslik seegi, et 1950. aastate keskel 1920. aastate alguse diskussiooni jätkava "Ajaloohuvi" historismi-peatükis viidatavate kaasaegsete autorite hulgas on ülekaalus vaimuteadlased, filosoofid ja teoloogid, mitte kolleegid ajaloolased.

Wittrami 1950.-60. aastate tekstidest pisut rutakate, kohati alusetute järelduste tegemisel pole nii professionaalne autor nagu Mommsen, kellel on suured teened Max Weberi Nietzsche-konteksti selgitamisel, sugugi ainuke. Korrektuuri vajab ka mõni 1990-ndate jooksul nn Oexle-koolkonna (O. G. Oexle, A. Germer, A. Wittkau) nimel käibesse sattunud eksiarvamus "Wittrami historismi" kohta, seda enam, et selle suuna tööd on kõrge teadusväärtusega.

(2) Raske on mõista historismi probleemajaloo ühe peamise initsiaatori Otto G. Oexle lapsust, sest midagi muud kui vääratus ei saa tema Meinecke historismi mõistet teravalt arvustavas kontekstis esitatud väide Wittrami kohta olla. Ta kirjutas 1996. aastal: "Ajaloolaste juures kehtis pärast 1945. aastat historism "lõpetatuna" [als "vollendet”], nagu 1958. aastal märkis Reinhard Wittram, või see kehtis - nii leidis 1965. aastal Theodor Schieder - millegi olnu ja iganenuna... Ja sel ajal, kui muudes kultuuriteadustes jäi väitlus historismi kui universaalse historiseerumise ning selle järelmite üle virulentseks, kehtis ajalooteaduses vaade, et historism olevat "lõpetatud asi" ja kuuluvat "ajalukku", "aktuaalset väljakutset" ta igatahes enam ei kujutavat, nagu nentis 1982. aastal Heinz Gollwitzer." Ise samuti Meinecke historismiteooriat arvustanud Wittrami üldsuhtumise edastusel on tegu Oexle möödalöömisega ideede mängus. Kontekstiväliselt näikse kujunevat mulje, et Wittram mõtleb "Ajaloohuvi" 5. loengu väljendiga der vollendete Historismus "historismi”, mis on 'lõpetatud, lõpule viidud, lõpule jõudnud' (aegumise tähenduses), samal ajal kui autorimõtte järgi on tegemist historismiga, mis on saanud täielikuks ja seega lõplikuks. Wittram peab siin historismiga silmas ajaloolise relativismi täielikku maksvusele pääsemist kultuurielus. On olemas põhjus, miks "tohib rääkida" vom "vollendeten" Historismus: "see läbib "vaimse maailma kõiki soppe' (Troeltsch), mitte ühtki sõna, õpetust, usutunnistust ei saa sellest välja arvata". ${ }^{83}$ Wittram annab vaimuteaduslikule historismile (äärmiselt

80 Wittram, R. Das Interesse an der Geschichte, 59 jj.

81 Samas, 67.

82 Oexle, O. G. Meineckes Historismus. Über Kontext und Folgen einer Definition. - Historismus in den Kulturwissenschaften, $191 \mathrm{jj}$.

83 Wittram, R. Das Interesse an der Geschichte, 60. 
aktuaalse) üldpoliitilise tähenduse. Kolonialismi asjus kirjutab ta järgmist: "Õiglane otsustus peab aga välja töötama ka Euroopa ajalooliselt ja ajaliselt tingitud mõtteja olemisviisid: historism tuleb maailmaulatuses täide viia [der Historismus muss im Weltmassstab vollendet werden]. ${ }^{84}$ Nii tunnustab Wittram ka poliitilist relativismi, sest ta ei tunnista ühtki "ajaloolise hetkega" määratud seletusmudelit absoluutseks. Sõnaajaloolistes märkustes orienteerub Wittram - võrreldes 1990. aastate teadmisega - ebakindlalt, kuid samas väärib tähelepanu, et tema oluliseks allikaks on historismi vaimuteadusliku teooria klassik Erich Rothacker. Üldiselt pole Rothackeri 1960. aasta väike artikkel "historismi"-sõna tarvitusloo pikendamisest 1830. aastateni, rääkimata selles implitsiitselt kätkevast vihjest Feuerbachile kui Nietzsche eelkäijale historismi probleemajaloos, kutseajaloolaste tähelepanu köitnud. Wittram loeb siiski ideearengu alguspunktiks Nietzschet, kes sõnakuju "historism" tarvitamata "igatahes [allerdings] kirjeldab midagi, mida võib igal juhul [jedenfalls] nimetada "historismiks"'. See on õige märkus, vaid ühe täiendava erisusega. Kui Nietzsche ilmutab Hegelit arvustades kartust, et "maailmaprotsessina" käsitatud ajalugu (Geschichte), mis paneb igat "oma aega" vaatama end ainult selle protsessi "paratamatu saadusena", on võtmas "teistelt vaimsetelt jõududelt", kunstilt ja usundilt nende sõltumatuse kultuuris, nii et kõige üle maksab "ajaloo võim" (vt $H L$ 8), siis Wittram nendib tõika, et nende kultuurijõudude sõltumist ajaloost on maailmas samamoodi jagamas teadus ja poliitika.

Ajalugu teadusliku ettevõtmisena, uurimisena, ajalooline relativism Wittrami jaoks ei tühista, küsimus pole ainult "faktiõigsuse" püsimajäämises, vaid ka selles, et elu situatsioonilisuse tõttu on ajaloo uuring eriti vastutusrikas mõistmisüritusena. Wittrami “Ajaloohuvi”-raamatu moraal ajaloolastele on mõistmisürituse samastamine teadusvabadusega, mis eksisteerib alati suhtelisena ja piiratuna "ajavõimuses". Niisiis mitte juba edu või saavutusena kõrgemal arenguastmel, vaid pigem uuriva teadlase alalise vaimse seadumusena mõistetavusele "edasiküsimise" teel - sellest, mis pole enam mõistetamatu, selleni, mida pole veel mõistetud. Võib-olla nende kaalutluste varal selgineb ka Wittrami küsiv definitsioon ajalooteaduse kohta artiklikogumikus "Tulevik ajaloos". Seoses arutlusega kiriku- ja üldajaloo vahekorra üle on ta lõpuks püstitanud küsimuse: kas pole "teaduslik ajalugu üldse" spetsiifika poolest ajateadus, "see üldine 'teadus ajast' (allgemeine 'Wissenschaft von der Zeit'), mida... saab olla ainult ajalooteadus ja mitte ükski teine teadus"? ${ }^{85}$ Relativistlik historism ei lase enam ajalool olla objektimäärangult positivistlik minevikuteadus. Möödunu on Wittrami käsituses "äraelatu", ja see on tema ajalooaja fenomenoloogias defenomenaliseeritud aeg ("jäistunud/ kangunud aeg"), millele tal vahel vastab ka selle ajakäsituse kohane ruumikujutlus ("antikvaarseks muutunud ajalooruum"). Samas näib hilist Wittramit olevat vaevanud sellise aja ja ruumi reaalsuse küsimus, millest annab tunnistust ka tema

84 Samas, 66.

85 Wittram, R. Möglichkeiten und Grenzen der Geschichtswissenschaft in der Gegenwart (1965/66). - Ders., Zukunft in der Geschichte. Zu Grenzfragen der Geschichtswissenschaft und Theologie. Göttingen, Vandenhoeck \& Ruprecht, 1966, 59. 
Nietzsche problemaatikale taanduv haridusliku ja kogemusliku ajalooteadmise (historische Bildung - geschichtliche Lehre) eristamine.

"Ajaloohuvi" 9. loengus, mis käsitleb ajaloost õppimise võimalusi, on ta selle suhtes võtnud järgmise seisukoha. "Sündmuskulus, tegutsedes ja kannatades, jälgides ja töödeldes, kaudselt või vahetult puudutatuna, võime olla õppinud mõndagi, mida nimetame meelsasti ajaloo õpetuseks; kõik muu on - sügavamalt või pinnalisemalt, kitsamalt või laiemalt - ajalooharidus või ka ainuüksi orienteerumisteadmine, vahel hädavajalik, üldjuhul soovitav, nagu kõik see, mis meie silmaringi avardab, mõnikord ka mitte ilma ohtudeta. Rikkaliku, aga õpetamata ja mittemetoodilise ajalooteadmise ohtlikkust ei suuda me enam näha tolles "ajaloohaiguses", millele Nietzsche 1874 oma teises "Ajakohatus vaatluses" ette heitis, et see "kahjustanud elu plastilist jõudu", mitte illusioone hävitavais "ajaloomeele liialdustes", vaid teatud kiusatuses, millesse ajalootundja näeb end sattuvat igal sammul - nimelt kiusatuses vahetada ära haridus- ja kogemusteadmine, visandada pinnakujunditega näivmaailm, langeda analoogiate meelepettesse. Kui ometi kõik need ajalooliselt nii teadjad poliitilised praktikud, kel me sõna saada lasksime, ei oleks arvanud ajaloost õppinud olevat!" ${ }^{\prime 86}$ Nietzsche peal koolitatud Wittrami kriitiline historism oli - pärast 1945. aastat - kaugel historismi "lõpetatuse" kujutlusest. Ajaloolise relativismi tunnistamine, selle mitmete aspektide teadusteoreetiline juurdlemine andis tema historismile ka poliitilise didaktika mõttes uue sotsiaalse funktsiooni.

Hiljemalt nüüd tuleks välja öelda käsitlustrendides fikseerunud autoriteetsete seisukohtade taustal teaduspoliitiliselt nähtavasti "ebapopulaarne" otsus. Eksitavate historiograafiliste seisukohtade olemasolu Wittrami historismi küsimuses 1970-ndaist kuni 1990-ndateni johtub, esiteks, tema rahvussotsialismiaegse Nietzsche-konteksti mittetundmisest ja, teiseks, teda kompromiteeriva fooni (1933-45) "ülerõhutamisest" minevikust "jagusaamise" eesmärgil. Tulem on üsna fataalne, see kõik on lülitanud historismi ajalooteaduse põhimõisteks pidava Wittrami 1980-ndate keskpaiku uuesti alustatud ${ }^{87}$ ja praeguseni kestvast historismidiskursusest välja.

\section{Wittram natsismi pitseri kandjana}

Natsism on pejoratiiv, aastakümnete eest teadustekstides pigem välditud kui tarvitatud hukkamõistev väljend natsionaalsotsialismi ja selle ajaloo kohta. Oli aeg, kus usuti, et "natsionaalsotsialismi" kasutamine ajaloolise terminina diskursuses on ajalooteadusliku objektiivsuse tunnus ning eristab teadlast kirjanikust,

86 Wittram, R. Das Interesse an der Geschichte, 117-118.

87 Historismi probleemajaloo uuendamise lähtepunktiks tuleb lugeda medievist Otto Gerhard Oexle artiklit, mis ajaloodistsipliini arengus väärib teadusteoreetilise saavutuse nimetust: Oexle, O. G. Die Geschichtswissenschaft im Zeichen des Historismus. Bemerkungen zum Standort der Geschichtsforschung. - HZ, 1984, 238, 17-55. (Algselt ettekanne Münsteri ajalooseltsis 8. detsembril 1982.) 
ajakirjanikust, filmitegijast või poliitikust, nendest, kes räägivad "natsismist" ja selle tuletistest või kandjatest, kujutavad asju poliitiliselt hindavast vaatenurgast. Kuid tegelikult sellise sotsiaalse usu kohaselt ei mõeldud ja sageli ka ei kirjutatud, poliitilised väärtustused, moraalsed hinnangud jõudsid peagi teadlaste poolt ja osalusel koostatud (ajalooliselt informeeriva iseloomuga) leksikonidesse. Teadlane on meie ettekujutuses liberaalse ühiskondliku süsteemi institutsioon, ta ei aktsepteeri massilist vägivallarakendust ja ei toeta võimugruppide omavolitsemist, mis hävitab lõpuks ka teaduse. Natsi-Saksamaa ajajärku käsitleva autoriteetse biograafilise leksikoni autor Robert Wistrich on koguni öelnud: "Kas pole siis tegemist Euroopa ajaloo lõiguga, mille puhul iga väide, olla objektiivne ja eelarvamusetu, mõjub lihtsalt ebasiiralt." ${ }^{\not 8}$ Olgugi et see väide ise ei ole laitmatu, sest objektiivsuse kategoorias ja taotluses peitub sisemine suundumus teadmise kvaliteetsuse ning universaalsuse poole ("lihtsalt"-arvamuste ületamisele), teadmise poole, mis oleks siduv, paranev, arendav teave võimalikult paljudele, kes eksisteerivad koos, on väite mõte igale lähiajaloolasele arusaadav. Natsism (küll mitte "ainulaadse"-ismina) eitas inimkondliku koeksistentsi printsiipi, ja viis õigusetult - oma ideoloogilise eituse ka ellu, õigemini surma. Otsene või kaasaaitavgi osalisus poliitikas, mis on selles mõttes äärmuslik, koeksistentse aluse suhtes "ekstreemne", ei saa olla vastuvõetav, õigustatav ega (inimlike vahenditega) lepitatav millegagi. Mõne passuse järgi hilisel Wittramil sugeneb lihtsast hüpoteesist tugevam oletus, et nii või umbes nii võis ta natsismi loomust mõista ka ise, kriitikuile arvamatult. Sellega võib olla ühtlasi seletatav Wittrami Göttingeniperioodil tema korduv pöördumine kristliku pärandi, eriti inimese "jumalanäosuse" probleemi käsitlevate vanimate allikate poole, teisisõnu, inimväärikuse teoloogia poole.

Kahtlemata on jätkuvaks Wittrami-kriitikaks olemas põhjus, tema kriitikuid ei saa süïdistada kriitikafaktis endas, sest mingil määral kannab Reinhard Wittram oma ideoloogirolliga "poliitilist vastutust". Veel umbes 15-20 aastat tagasi baltlaste endi või baltlusele sümpatiseerijate hulgas käibinud pruuk kõnelda pehmendavalt Wittrami rahvussotsialistlikust eluperioodist on - historiograafilise etapina - oma ajaülesande täitnud, aga ka oma aja ära elanud. Wittram ei olnud poliitiliselt neutraalne, ja ta ei olnud seda veendumuslikult, sest poliitilisus kätkes ajaloomõistes, mis oli tema arust teadlasekutsele siduv. "Ajalugu kui ajalooteaduse objekt on oma sisimalt olemuselt [ihrem innersten Wesen nach] poliitiline ajalugu, st sel on tegemist inimliku võimu ja väega, mis teostub riikides ja rahvastes," kirjutas ta 1930. aastate keskpaiku. ${ }^{89}$ Kui Wittrami "võimu"-mõiste oleks ühenduses natsistlikult interpreteeritud Nietzschega, siis oleks tema ajaloomõistes politiseeritud nietzscheanismi - selle kohta meil otsest tõendit pole. Üle 20 aasta hiljem (1959/64) baltlaste "organiseeritud" natsiliikumist analüüsides ja ka oma osa

88 Wistrich, R. Wer war wer im Dritten Reich? Ein biographisches Lexikon. Anhänger, Mitläufer, Gegner aus Politik, Wirtschaft, Militär, Kunst und Wissenschaft. Überarb. und erw. von H. Weiss. Frankfurt a. M., Fischer Taschenbuch Verlag, 1987, 8.

89 Wittram, R. Die Wendung zur Volksgeschichte. - BMH, 1936, 10, 569. 
"müütilises ajaloopildis" armutult kritiseerides on Wittram küll arvanud, et selle "pärisallikat" tulevat otsida "rahvuslikkuse tahtesfäärist" (in der Willenssphäre des Nationalen). Tema arusaamale, et kohaliku liikumise sünni ümber käinud poleemikas - riialase Erhard Kroegeri ja tallinlase Hans Schultzi vahel - "oli motiivina tunda" ka "Nietzsche võimutahet" (Kroegeri juures tajunud seda Wittrami meelest "täiesti õigesti" Schultz) ${ }^{90}$ tuleb lisada, et ta enda tekstides puudub hitlerlike kasvatuseesmärkidega seotud võimutahte (pseudo)nietzschelikul printsiibil iseseisev tähtsus. Definitsioonist, mida sai tsiteeritud, on välja loetav, et tahteprintsiip lahustus tema - kahtlemata võitluslikkuse tunnustega - ajalookujutluses: "ajaloo olemus" oli Wittramile tookord poliitiline tegevus; ning seda on ta samuti rõhutanud väitega, et (rahva)ajaloo taandamine "bioloogilisele eksistentsile" ja selle protsessidele tegelikult "rikub ajaloomõiste" (verdirbt den Geschichtsbegriff). Ajaloo subjektiks rahvaajaloo mõttes oli Wittramile kollektiivne tegutseja "poliitiline rahvas", kes kujutas endast "mõõdupuud, mis ulatub üle kogu ajaloo". Wittrami käsituses ajaülest kontinuiteeti kehastava rahva poliitilisus osutab sügavatele paralleelidele rahva kontseptsiooniga Hans Freyeri "saksa sotsioloogias". Järeldus kõigest sellest on päris ühene: Wittram ei kuulu nende ajaloolaste hulka, kelle kohta nüüdishistoriograaf võiks öelda, et nad lasksid end rahvussotsialismist kaasa haarata või sisse tõmmata. Neile saab kohaldada "passiivse koostöö" ebamäärase klausli, Wittramile aga vaevalt (kaalukeeleks ei saa siin olla isegi natsiparteilisus, nt Freyer ei olnud parteiliige). Erinevalt sellistest tegi Wittram natsirežiimiga teadlikult koostööd: 1930-ndate lõikes on ta roll määratletav niihästi "NS-ideoloogia" pooldajana (nn Anhänger) kui "NS-liikumise" aktivistina, kes innustas teisi rahvussotsialismiga kaasa minema; 1940-ndate algupoolel, kui ta oli Poseni (Poznańi) ülikooli filosoofiateaduskonna dekaan, võib teda pidada vastutavaks natsismi kõrghariduspoliitika eest okupeeritud aladel. Ajaloolises juhtumiuurimises on aga siiski lubatud valida üldjoontes kahe strateegia vahel: kas otsida tõhusamat hukkamõistu kriteeriumi või sondeerida pinda mõistmiseks. Lähiajaloo uurimises on peale selle sõltuvalt olukorrast vaja ideologiseeritud "avalikku sõna" (kui umbisikulist vokabulaariumi) eristada personaalsetest allkoodidest - ka Wittrami juhtumil.

Wittrami suhetele Nietzsche vaadetega, õigemini nende uurimisele historismi kriitika ja teooria aspektist, mis teeb need suhted meile aktuaalseks, "vajutab pitseri" tema 1930.-40. aastate rahvussotsialistlik minevik mitmeti. Piltlik ütlus sugereerib positivistliku historismi idee, nagu oleks tegu "ajaloo enese" otsusega. Et Wittramil oli rahvuslik-poliitiline minevikusüü südame peal ka tema teadus-

90 Vt Wittram, R. Rückblick auf den Strukturwandel der deutsch-baltischen Volksgruppen im letzten Jahrzehnt vor der Umsiedlung. - Festschrift Percy Ernst Schramm. Zu seinem siebzigsten Geburtstag von Schülern und Freunden zugeeignet, II. Wiesbaden, Franz Steiner Verlag, 1964, 231-250, siin 242.

91 Wittram, R. Die Wendung zur Volksgeschichte, 570.

92 Vt Muller, J. Z. The Other God That Failed. Hans Freyer and the Deradicalization of German Conservatism. Princeton, New Jersey, Princeton University Press, 1987, passim. 
tegevuse kõrgajal (1950.-60. aastail), ei saa ükski ta hilisemaid töid korralikult tundev aus ajaloolane eitada. Aga ta ei esinenud kunagi ka mingi avaliku patukahetsusega, pigem võib leida tema sõjajärgsetest artiklitest poleemikat "süüküsimuses", mille juures ei puudu nn lepitamatu süü allusioon. Wittram eristas evangeelse luterlasena selles küsimuses talle nähtavasti olulisemat teoloogilis-sisemist kihti (süüme kui instants ja kui kahekõne) ${ }^{93}$ ideoloogilis-avalikust tunnistusest.

Kahjuks võib seesama "pruun minevik" Wittrami puhul äratada valdavalt või ainult stereotüüpseid, ütleme, Nietzsche pärandit rahvussotsialismi "pedagoogiliste" sihtidega ühitanud "teadusjuhi" Alfred Baeumleri (1887-1968) stiilis politiseeritud assotsiatsioone. 1935. aastal kurikuulsa Ajaloo Riigiinstituudi (nn Franki instituudi) auliikmeks valitud Baeumler natsifitseeris Nietzsche põhilised mõisted: "Üleinimene kujutab endast kristlik-demokraatliku, liberaal-optimistliku Euroopa ületamist." ${ }^{94}$ Ent selle kõrvale võime tuua Nietzsche enda väite, mis on pärit "võimutahte" perioodist (nr 262): "Igal ühiskonnal on tendents oma vastaseid kuni karikatuurini - vähemalt oma kujutluses - alandada ja nagu ära näljutada. Üks selline karikatuur on nt meie "kurjategija". Keset roomalik-aristokraatset väärtuste korda alandati karikatuuriks juut. ${ }^{95}$ Nietzsche ei jäta siin lisamata, et ka tema pilt Platonist on karikatuurne. On raske murendada stereotüüpe, millel on karikatuuri vorm, kuid see kuulub kriitilise seadumusega ajaloolase töö juurde. Nietzsche kujundite ja piltide maailma 1930-ndail avada püüdnud Paul Fechter tunnetas Nietzsche olemuse sõnalises teostuses "eredalt impressionistlikku inimest". ${ }^{96}$ Kuidas panna selline inimene parteid võimule vedava ideoloogia vankri ette, väänamata sobivaks ta vaimset meediumi - pilte, sõnu, ütlusi? Nietzsche loomingu perioodiline vastuolulisus, ka fragmentsus ja aforistlikkus tingib, et

93 Vt selle kohta nt Salumaa, E. Evangeelse eetika alused. Toim J. Noormägi. (EELK Usuteaduse Instituudi Toimetised, XI.) Tallinn, EELK Usuteaduse Instituut, 2003, 92-98. - Vrd ka Wittrami II maailmasõja järgses loomingus tähtsal kohal oleva "avalikku pahet" (valetunnistuste andmist kaasinimese vastu) keelava 8. käsu kommentaari Lutheril: Luther, M. Suur Katekismus. [Tlk E. Salumaa.] Tallinn, EELK Konsistooriumi kirjastusosakond, 1996, 77-86.

94 Baeumler, A. Nachwort. - Nietzsche, F. Also sprach Zarathustra. Mit P. Gasts Einführung und einem Nachwort von A. Baeumler. Stuttgart, Alfred Kröner Verlag, 1941, 416 jj. - Et "üleinimest" on vulgaarne samastada Nietzsche-järgselt sellele omistatud "antikristliku tähendusega", näitab veenvalt Ernst Benzi mõisteajalooline detailuurimus: Benz, E. Der dreifache Aspekt des Übermenschen. - Eranos-Jahrbuch 1959, XXVIII: Die Erneuerung des Menschen. Hrsg. von O. Fröbe-Kapteyn. Zürich, Rhein-Verlag, 1960, 109-192. Vrd "üleinimese" mõisteliste suhete kohta muude inimese-tähistustega Nietzsche erinevais tekstides ka Nietzsche-pildi ühe kõige väljapaistvama "denatsifitseerija” Walter Kaufmanni analüüse: Kaufmann, W. Nietzsche. Philosopher, Psychologist, Antichrist. 4th Ed. Princeton, New Jersey, Princeton University Press, 1974, eriti 307-316; samas (316) on rõhutatud, et "türannia teiste üle ei ole Nietzsche [üleinimese-] visiooni osa".

95 Nietzsche, F. Der Wille zur Macht. Zweites Buch: Entstehungslehre des Willens zur Macht. B. Das neue Prinzip: Leben als Wille zur Macht (Aus dem Nachlass 1885-88). - Ders., Werke in vier Bänden, II. Wien, Caesar Verlag, 1980, 208.

96 Vt Fechter, P. Nietzsches Bildwelt und der Jugendstil (1935). - Jugendstil. Hrsg. von J. Hermand (Wege der Forschung, CX). 2., unveränd. Aufl. Darmstadt, Wissenschaftliche Buchgesellschaft, 1989, 349-357. 
teda saab kasutada sama hästi nietzschelikult kui ebanietzschelikult, rääkimata Karl Schlechta selgitatud Nietzsche õe võltsinguist (sekkumisest venna käsikirjadesse ning tema stiliseerimisest antisemiidiks). Nietzsche teoste 1960-ndail ilmuma hakanud uue tekstikriitilise editsiooni kaasettevalmistaja Giorgio Colli pidas tsitaatide kasutamist Nietzschelt seetõttu üldse ebasoovitavaks! Täiesti ühemõttelist nietzscheanismi, mida Wittramile pookida, tegelikult ei ole, ja mingites - nt poliitilise ideeajaloo - piirides on samasugune lugu tema natsismiga, mille iseloomustused ulatuvad 25 aasta jooksul (1972-97) eufemismidest kritikaanluseni.

Põhjendatud on ideoloogialoolasena samuti Nietzsche ja filosoofilis-poliitilise nietzscheanismi suhteid analüüsinud Ernst Nolte 1988. aastal (seoses Baeumleriga) püstitatud küsimus: "Kas polnud rahvussotsialism, mida iganes ta muidu veel oli, ka euroopaliku rahvusluse üks vorm?" ${ }^{97}$ Wittramile, arvestades ka poliitilisteadusliku kireni ulatuvat huvi, mida ta tundis natsionalismiprobleemi vastu, oli rahvussotsialism ehk - 1954. aasta määratluses - "juhitud rahvuslus" (der gelenkte Nationalismus $)^{98}$ seda ennekõike. Üldiselt pole tähele pandud asjaolu, et rahvusprintsiibi prisma läbi võttis Wittram pärast sõda kriitika alla igasuguse totalitaarse võimupoliitika järelmid. Rahvuslike "tundekomplekside" ja "ürginstinktide" ärakasutamine võimukujunduses ("ilma sisemise suhteta neisse") viivat selleni, et Euroopa jaoks "hävitatakse" tema "rahvasteühendust" vääriliselt mõtestav olend - see tähendab "inimene", kellele selle ühenduse "rahvuslik-kultuurilisel diferentseerumisel" põhinevad väärtused on tema "hingeline omand ja vaimne vajadus". Teiselt poolt, "rahvuslikkuse ümberhindamise" (die Umwertung des Nationalen) vajadust rõhutades, piiras Wittram II maailmasõja järel rahvusluse ideoloogilist tähtsust ja rahvuslike tõdede tähendust: "Pole võimalik kruvida rahvuslikku solidaarsust üles tõevõitluste sfääri, käsitada otsustamist rahvuse kasuks kui seisukohavõttu viimsetes küsimustes." $" 99$

Implitsiitselt oli see Wittramile iseenda kriitiline ümberhindamine, täpsemalt, oma teadusliku ajalookirjutusmudeli depolitiseerimine. Mudeli, mis veel tema 1940. aasta määratluse kohaselt oli balti traditsioonis "vaimne-poliitiline võim" ning mille "tähendus" baltlastele - "rahvarühma rahvuslikule enesetundele" (für das völkische Selbstgefühl der Volksgruppe) - oli "väga suur". ${ }^{100}$ Sõjaeelse Wittrami mõni arutlus Baltimaade ajalookirjutuse käigu üle annab alust väiteks, et oma kuulsa "pöördega" rahvaajaloo poole ei mõelnud ta "katkestust", vaid "uuendust". Teisisõnu, maaloolise käsitlusviisi omamoodi intensiivistamist rahva-

97 Nolte, E. Philosophie und Nationalsozialismus. - Heidegger und die praktische Philosophie. Hrsg. von A. Gethmann-Siefert und O. Pöggeler. Frankfurt a. M., Suhrkamp Taschenbuch Verlag, 1988, 348.

98 Wittram, R. Wandlungen des Nationalitätsprinzips (1954). - Ders., Das Nationale als europäisches Problem. Beiträge zur Geschichte des Nationalitätsprinzips vornehmlich im 19. Jahrhundert. Göttingen, Vandenhoeck \& Ruprecht, 1954, 90.

99 Samas, 92.

100 Wittram, R. Die livländische Geschichtsschreibung (1940). - Ders., Rückkehr ins Reich. Vorträge und Aufsätze aus den Jahren 1939/1940. Posen, Universitätsbuchhandlung Kluge \& Ströhm, 1942, 171. 
looliseks ja seeläbi ajalooteadvuse - varasemaga võrreldes - veel tugevamat, tõhusamat politiseerimist. Politiseerimine, milles Wittram ise etendas juhtivat osa, ei tähendanud lõppkokkuvõttes midagi muud kui ühe kolonistide järglastena identifitseeruva põlvkonna ajalooteadvuse muutmist rahvussotsialistlikuks baltlaste rahvusluse vormina. 1940 Johannes Halleri juubeliks avaldatud "Riik ja balti sakslased", 1942 muudetud pealkirjaga "Riik ja tema vanim koloonia", ei jäta kahtlust, et "baltisaksa rahvaühisusteadvus" (Wittrami-ajaloolase natsionalistlik soovkonstrukt) on poliitilise ideena natsionaalsotsialistliku liikumise "totaalse rahvusliku ühisusega" kongruentne. ${ }^{101}$ Nietzsche elutahtelise individualismi ideel ei ole selle poliitilise kogukonnaidee realisatsiooniga midagi ühist. Ajaloolise teadvuse hingi ühendav jõud seondub Nietzschel antikvaarse, mitte aga kriitilise meelega ("antikvaarne inimene" isegi "vahel tervitab" üle sajandite "oma rahva hinge omaenese hingena"), see ühisidentiteet ahendab indiviidi ("inimese, linnakogukonna, kogu rahva antikvaarsel meelel on alati ülimalt piiratud vaateväli") (HL 3). Baltlaste ühisusteadvuse rahvussotsialistliku ideaali propagandistlikul teostamiskatsel esineb Nietzsche juba märksa rohkem Wittrami püüete arvustaja kui toetaja rollis. Nietzsche ei eitanud antikvaarse hoiaku tähtsust ja isegi õigustust, kui see on seotud ajaloolise "tõepüüdlusega", ent ta täheldas ka selle hoiaku küsitavust ja kahjulikkust, eriti siis, kui tegu on hulki valdava ajaloo mõistlikkuse "mütoloogiaga". ${ }^{102}$

\section{Ekskursid uuemasse Wittrami-kriitikasse (Rassismiküsimus)}

Sotsioloogia mõisteid kasutades võib varase perioodi Reinhard Wittramit tema rahvusliku valiku põhjal nimetada kindlasti "etnotsentriliseks isikuks". Kas poliitiliste valikute alusel, mida ta ajaloolase elukutse esindajana tegi ja ühtlasi oma kirjatöödes mõjuvalt kajastas, märgistada teda ka rassismiga, nimetada teda natsismi ühe olulise komponendi järgi "rassistlikuks ajaloolaseks", on historiograafiline vaidlusküsimus. On tunnuslik, et rassismiküsimus kuulub tänapäeval (sotsiaal)ajaloolaste tekstides natsirežiimi poliitilise kriitika valdkonda ja mineviku kriitika peab muu hulgas täitma ajalooteaduse demokratiseerimise ülesannet. Üldjuhul paistab olevat kõrvale jäänud rassi mõiste seadmine historismikriisi problemaatika valgusse, nagu tegi oma artiklis "Historismi kriisist" (1942) veel Friedrich Meinecke. ${ }^{103}$ See historismiloo klassik, kes juba 1920-ndail oli arvustanud primitiivset "rassikultust" moodsas natsionalismis, tõlgendas ise selliseid mõisteid nagu Volkstum ja Rasse "ajaloolise elu" kirjeldamise aspektidena. Meinecke

101 Vt Wittram, R. Das Reich und seine älteste Kolonie (1940/42). - Ders., Rückkehr ins Reich, $70-72$.

102 Vt selle kohta Salaquarda, J. Studien zur Zweiten Unzeitgemässen Betrachtung, 21 jj.

103 Vt Meinecke, F. Von der Krisis des Historismus (1942). - Ders., Zur Theorie und Philosophie der Geschichte (Werke, IV). Hrsg. und eingel. von E. Kessel. 2. Aufl. Stuttgart, K. F. Koehler Verlag, 1965, 197, 201 ja 203. 
võttis neid (partei)poliitiliselt enam-vähem neutraalselt, ajaloo mõistmise osana ja historistliku individuaalsusidee võtmes. Wittrami "rassi"-mõiste konkreetsete allikate ja funktsioonide kohta, ennekõike 1930-ndail, meil spetsiaalset uurimuslikku teavet pole. Küll aga võib öelda, et (a) natsismi õpetusele iseloomulikku rahvaste "rassipoliitilist hierarhiseerimist" ning (b) rahva ja rassi mõistete hitlerlikku "sünonüümiat" $" 104$ me tema tekstidest ei avasta. Tegelikult on rassismiküsimus osa Wittrami "natsiseotuse" elementide (konservatiivsus, irratsionalism, rassiprintsiip) kombinatsioonist, nagu see kerkib esile tänastes vaatlustes.

Historiograafias on 1992. aastal tehtud paljastusakt, Wittrami II maailmasõja aegsete (1942/43) artiklite põhjal on talle omistatud "rassistlik tendents" ning ta on liigitatud lõpuks nende 8 saksa ajaloolase hulka, kes "avalikult toetasid" Nõukogude Liidu vastast "massimõrva programmiga seotud agressiooni". Resümee on ajaloolaste natsiseotuse sotsioloogia ("kriitilise valgustuse") järel esitatud poliitilise süüdistuse stiilis: "Nad legitimeerisid seda sõjakäiku kui reaktsiooni sajanditevanusele ja nüüd bolševismiga uude kvaliteeti jõudnud idapoolsele/ asiaatlikule ohule. Bolševismi taotletud hävitamisega näidati ära radikaalne perspektiiv." ${ }^{105}$ Niisugusel hinnangul on lähiajaloolastele oma mõju, see võib euroopastuva ajalookultuuri tingimustes - nn projektiajaloo konsensuspoliitilisel suunamisel - mõjuda isegi tõkendina suhteliselt algfaasis olevale Wittrami-uurimisele, kuid see hinnang ei ole täiesti õiglane ja seega ka mitte päris objektiivne. Vaatepunkt, et sõjaolude teravustatud artiklid peegeldavad episoodi Wittrami Venemaa-pildis, mille üheks tervikuks kokkuseadmine Balti-Vene poliitiliste suhete käsitlusmudeli mõttes laseb otsustada, kas saab (või ka ei tohi) anda "legitimatsiooni" selliselt - poliitilise summana - langetatud hinnangu elementidele, on ajaloolise objektiivsuse tekstuaalsusega hästi põhjendatav.

Karen Schönwälderi kui osundatud hinnangu autoriga võib polemiseerida ka selle üle, kas Wittrami sõjaaegset (faktidel rajanevat) kriitikat Vene imperialismi ja Lenini (ajalooliselt kuritegeliku) isiku pihta balti ajaloolase negatiivseks kujutamiseks esile tuues ei riski uue paljastusajaloo mõni peatükk ise muutuda sovetismi õigustava poliitilise tendentsi kajastajaks ajalooteaduses. Geneetilises seoses varasemaga, ainult et ilma sõja ajale omaste rahvussotsialistlike alltoonideta, on ka Wittrami sõjajärgne analüüsimeisterlik käsitlus Vene imperialismist üksikutes võrdlusjoontes keiserliku ja sotsialistliku Venemaa vahel koos ajaloofilosoofiliste tähelepanekutega imperiaalsest traditsioonist vene poliitilises kultuuris. "Traditsiooniseose" tähenduses ei välistanud Wittram tuleviku Venemaal "vanale ekspansioonipüüdele uut mõtteandmist", ${ }^{106}$ see tema 1959. aasta kaalutlus on mitte ainult natsismi ja stalinluse, vaid ka Afganistani okupatsiooni ja Nõukogude

104 Rassiteooria kohta vt nt ka Baltikumi-ainelist tööd: Blank, M. Nationalsozialistische Hochschulpolitik in Riga (1941 bis 1944). Konzeption und Realität eines Bereiches deutscher Besatzungspolitik. Lüneburg, Verlag Nordostdeutsches Kulturwerk, 1991, 47-54, siin 48.

Schönwälder, K. Historiker und Politik. Geschichtswissenschaft im Nationalsozialismus (Historische Studien, 9). Frankfurt/New York, Campus Verlag, 1992, 260 jj.

106 Vt eriti Wittram, R. Das russische Imperium und sein Gestaltwandel. - HZ, 1959, 187, 568 593 , siin 592. 
impeeriumi minevikuks saades võimu- ja geopoliitiliselt aktuaalne. Schönwälderi hinnang tugineb põhiliselt ühele kuue artikliga kogumikule "võitleva rahvaühisuse" ajast (1942; enamik on kirjutatud 1940/41), kahele artiklile Venemaa-sõjakäigu ajast (1943; "Sakslane Euroopa sõdurina" ja "Vene imperialismi olemusest") ning ühele enne sõda (1937). Kas lugeda ka fakti, et septembris 1944 telliti Wittramilt Saksa poolel sõdinud vene vabadusvõitlejate toetuseks "ajaloopilt", balti ajaloolast tänapäeval diskrediteerivaks või mitte, sõltub minu arvates sellestki, kuidas me hindame nende võitlejate nüiud meile teada olevat saatust. Olgu märgitud, et hilise, "sotsiohumanistliku" Wittrami üks kaalukaid töid filosofeeriva ajaloolasena on vabaduse probleemist Vene lähiajaloo otsustava aasta - 1917. aasta näitel, Lenini diktatuur ja tegevus on aga selles töös vabaduse kaotamise sümbol. ${ }^{107}$ Ei keegi muu kui Nietzsche kirjutas 1878. aastal: "Niisamuti peab sulle olema ajalugu hästi tuntud ja ettevaatlik mäng vaekaussidega: 'ühelt poolt - teiselt poolt'.",108

Analüütilisem ekskurss Wittrami rahvussotsialismi elementidesse ei ole siin võimalik, ent tasub märkida, et selle kultuurikriitiline taust pole ka nii ühemõtteline, nagu paistab. Näiteks samuti kui natsismiga ajuti ühte jalga astunud baltlane Wittram, oli ka natsismile sõnaga vastu astunud (Saksa okupatsiooni ajal 1942 interneeritud) ja sellisena samas ajasituatsioonis pigem tema antipoodina esinev hollandi ajaloolane Johan Huizinga, kes ei jaganud elufilosoofia ja poliitilise eksistentsialismi postulaate, bolševismi ja amerikanismi, "organisatsiooni" ja "mehhaniseerimise" otsustav kriitik. "Oleme küllalt 'progresseerunud' võimes seda maailma ja oma ühisust laostada. [...] Teadusest ja tehnikast ei piisa kultuurielu vundamendi loomiseks"109 - see Huizinga väide annab edasi tajutud kriisi üht aspekti. Kriisi teist aspekti vahendab Wittrami tees: "Rahvas säilitab oma kehatervise ainult siis, kui tema seosed metsa ja põlluga on tihedamad kui linnade asfaldiga." $" 110$ Antipoode ühendab, kui nii võiks öelda, kultuuri loovjõudude kriisi tunnetamine, probleemi lahendusteid aga nähakse väga erinevalt, kas liberaalse "logose" või autoritaarse "müüdi" võtmes. Tänapäev on harjunud selles nägema humanismi ja antihumanismi vastandlikkust, kuid teataval määral võib siin näha ka humanismi enda sisemist ambivalentsi. Wittramile, nagu ta oma 1938. aasta "Märkustes kultuuri, rahva ja stiili kohta" rõhutas, ${ }^{111}$ oli kultuur, mille "sümboliks on keel", võõrandumisele vastu seisev "rassi- ja rahvaseoseline" loovus ning hingeline elamussisu, kultuuri "süvaallikas" oli tema nägemuses rahvakultuur (Volkskultur). Ka oli tema kultuurimõistes olulisel kohal ("eriti ohtlik")

107 Vt Wittram, R. Die Freiheit als Problem der russischen Provisorischen Regierung (März bis Juli 1917). (Vortragsreihe der Niedersächsischen Landesregierung zur Förderung der wissenschaftlichen Forschung in Niedersachsen, 48.) Göttingen, Vandenhoeck \& Ruprecht, 1973, 3-32.

108 Nietzsche, F. Menschliches, Allzumenschliches, 1. Band, 5. Hauptstück: Anzeichen höherer und niederer Kultur (Nr. 292). - Ders., Werke, Erster Teil, 383.

109 Vt nt Huizinga, J. Im Schatten von morgen. Eine Diagnose des kulturellen Leidens unserer Zeit. Bern/Leipzig, Gotthelf-Verlag, 1936, 185.

110 Wittram, R. Einige Bemerkungen zum Verständnis der Gegenwart. - BMH, 1937, 2, 130.

111 Vt Wittram, R. Bemerkungen über die Kultur, das Volk und den Stil. - BMH, 1938, 7/8, 436439. 
keelelise võõrdumise teema, eriti seoses venestamise kogemustega baltlaste hulgas, ta pidas enesestmõistetavaks, et kultuur vajab hoolt ja kaitset, kuid tema mõtisklusi läbib samuti - mitte just päris süütu - kultuuri "puhtana hoidmise" idee. Rahvalik-rassiline kultuurikäsitus pole aga Wittramil midagi otseselt sõjakat, sellist kultuurilise tingituse usku, mille ta sidus "ruumilise antuse" faktoriga kultuuriringide teooria mõttes, jagasid paljud. Tähtis on, et tema enda arvates, n-ö teadvuse faktina, oli see põhiliselt konservatiiv-orgaaniline arusaam kultuurist "kõige üldisemalt inimlik" (das am allgemeinsten Menschliche). Karl Mannheimi 1927. aasta konservatismi-sotsioloogia mõistete valguses saaksime Wittrami hoiakut iseloomustada kui originaarse konservatiivse kogemuse muutumist refleksiivseks, see tähendab, oma eripärast teadlikuks, end teistest samas "eluruumis" toimivaist mõttelaadidest ideoloogiliselt eraldavaks ja end nende vastu kaitsvaks. ${ }^{112}$ Iseloomustada Wittrami konservatiivsust politoloogilise levimõistega "konservatism", lahus poliitilise radikalismi vormidest nn Balti ruumi ja selle piirialade võimusuhetes ning ajaseisundites, ei oleks sotsiokultuuriliselt adekvaatne.

Publitsistina erakordselt andekas Wittram, olles ka habiliteerunud 28-aastane kutseajaloolane, tunnistas end 1930. aastal avalikult tollases Euroopas populaarseks muutunud antidemokraatliku "konservatiivse revolutsiooni" idee pooldajaks. Juba see pooldamise akt viis teda ajaloolasena eri poliitiliste suundade võitlusse, mille tander ei olnud ainuüksi paikne baltisaksa kogukond oma sotsiaalse teadvuse kujundamise (Wittrami järgi: "uuestivormimise") probleemiga ega väikesed Balti riigid. Lähtudes ise "balti kodupinnase" tsivilisatoorse ohustatuse tundest ja lugedes oma aja inimeste meeleoludest välja "demokraatiavaimu väsimise" märke, käitus ta siis enda arvates ka kultuuriohtlikest "jõududest" kommunismist ja amerikanismist vaenatud euroopluse propagandistina. ${ }^{113}$ Wittram vastandas end poliitilises mõtlemises baltlaste põlisele kujutlusele oma eristaatusest Venemaa perifeerias ning kaasas baltisaksluse poliitika arutlusse üha välispoliitilise orientatsiooni - Saksamaale kui "poliitiliste kujutluste" eeskujule. On raske öelda, kui siirad olid tema püüded hajutada irredentismi kahtlusi asukohariikides, igatahes artiklis "Saksa ja balti" (aprillist 1933) nõudis ta resoluutselt baltisakslaste "kõige täpsemat lojaalsust" Eesti ja Läti rahvusriiklusele ning kirjutas: "Me peame teadma, et kuulume koos oma kaasmaalastega Kesk-Euroopasse, mitte venelikku Idasse."114 Wittrami 1930-ndate rahvaloos jäädvustatud väljend Ida-ohu kohta ("bolševistlik hirmuvalitsus") ei ole vaid "1919. aasta süngete kuude" ümber loodud mütologeem: see on ka sümboolne tähistus võimule, mis ei hooli rahvuslike kultuuride

112 Vt Mannheim, K. Das konservative Denken. Soziologische Beiträge zum Werden des politischhistorischen Denkens in Deutschland (1927). - Ders., Wissenssoziologie. Auswahl aus dem Werk (Soziologische Texte, 28). Eingel. und hrsg. von K. H. Wolff. 2. Aufl. Neuwied a. Rh./Berlin, Hermann Luchterhand Verlag, 1970, 445 jj. - Konservatismist kui poliitilisest ideoloogiast ajalooliselt ülevaatliku pildi annab Robert Nisbet, vt Nisbet, R. Conservatism: Dream and Reality. Minneapolis, University of Minnesota Press, 1986.

113 Vt eriti Wittram, R. Liberal und konservativ als Gestaltungsprinzipien baltischer Politik, 229232.

114 Wittram, R. Deutsch und baltisch. Zum Verständnis der deutschbaltischen politischen Tradition, 201. 
õigustest. Aga siit jäi noorel Wittramil teha ainult väike samm teistsuguste võimuhuvide rüppe, mille barbaarseid tagajärgi ta oma etnotsentrilisest vaatepunktist algul ette ei näinud. Küll teisiti kui läbilõike-rahvussotsialist, oli Wittram baltlaste ideoloogina afitseeritud natsismipärasest indiviidi ja kogukonna, maa ja linna, rahva ja riigi käsitusest. Afitseeritus, puudutatus, tabatus kui olek/hoiak tundub sobivat selle ideoloogilise seisundi kirjeldamiseks, millest Wittram oli haaratud ja mille baasil ta püüdis arendada mingit enesekaitse või eksistentsiabi poliitikat. Seda tõendavad tema arvukad "elu suurte asjade" - "inimese olemisküsimuse" $" 115$ ja "rahvasteelu loomulike aluste" 116 _ "uuele mõtestusele" orienteeritud päevapoliitilised-kultuuriteoreetilised tekstid enne 1939. aasta Umsiedlung' it $^{117}$ (natsipartei liige oli ta juunist 1941, ilmselt oli see Poseni ülikooli korralise professuuri - maist 1941 jaanuarini 1945 - vältimatu tingimus). Nende põhjal ei saa jagada (1937. aasta teksti suhtes) avaldatud arvamust, et Wittram kirjutas "poolehoiuavaldustega rassistlikele kontseptsioonidele [!]". ${ }^{118}$

Wittrami ja teiste rahvaloolaste seisundi kirjeldamine selle tavamääratlusega rahva/rahvalikkuse "irratsionaalne kirgastamine" (irrationale Verklärung) -, mida üksteisest sõltumatult tarvitavad nende aadressil nüïdisuurijad (nii K. Schönwälder kui W. Oberkrome), näib olevat lõivumaksmine žargoonile. Balti rahvauurimises oli tollal olemas Max Weberi arusaamadega haakuv teaduslikkuse kui "süstemaatilise ratsionaalsuse" refleksioon. Wittrami vanem kolleeg, Herderi ja Kanti uurijana tuntud Kurt Stavenhagen (1885-1951) arendas selle põhjal rahvateoorias välja kaht tüüpi, statsionaarse ja progressiivse (fenomenaalse) ajaloolisuse kontseptsiooni. ${ }^{119}$ Mingist rahvaliku eriliselt irratsionaalsest kirgastamisest ei saa ka

115 Wittram, R. Der Staub an den Füssen. - BMH, 1936, 10, 691.

116 Wittram, R. Einige Bemerkungen zum Verständnis der Gegenwart, 131.

117 Ümberasu(sta)mise kohta 1939/41, mis kujutab endast poliitilise lähiajaloo sündmust, on "Eestimaa-baltlane" Georg von Rauch 1970-ndail märkinud selle kaasaegse põlvkondliku tajumise erinevust baltisakslaste hulgas: "Vanemale generatsioonile oli see enamasti väga valuline lahkumine kodumaast ja tema seitsmesaja-aastasest ajaloost, mida ainult osaliselt leevendas teadmine rahvuslikust seotusest saksa rahvaga. Noorema põlvkonna puhul oli määravaks just viimane, peale selle veel uute ülesannete ootus süsteemis, mille poliitiline, õiguslik ja moraalne küsitavus alles hiljem ilmsiks sai." (Rauch, G. v. Balti riikide ajalugu 1918-1940. [Tlk E. Rõngelep.] Tallinn, AS Detlar, 1995, 103.) Ometi on ka Wittrami puhul, kes kuulus just sellesse nooremasse põlvkonda, tema enda põlvkonnakaaslane ja samuti Halleri-õpilane Wilhelm Lenz kõnelnud "ümberasumisest, mis oli talle (Wittramile) väga raske" (Lenz, W. Reinhard Wittram. - BB, 1973, 5/6, 5). - "Kodumaalt lahkumise" peegelduste kohta baltlaste kirjanduslikus loomingus vt Garleff, M. Ajalooline kogemus baltisaksa kirjanduses. [Tlk H. Vaakmann.] Looming, 1995, 9, 1232-1246. Eestlastest kaasaegsete võidutseva reaktsiooni, sh poliitilise naivismi ja "mentaliteetide kokkupõrke" (rahvus)ajalooliste näidete kohta vrd ka: Kivimäe, J. Raske lahkumine. Baltisakslaste ümberasumine eestlaste rahvuslikus vaatevinklis. - Looming, 1989, 9, 1242-1250. Hiljuti publitseeritud "sündmuses osaleja" Ella Vende (1901-1987) mälestused baltlaste lahkumise kohta Eestist (vt Vende, E. Idamissiooni lõpp (1975). - Tuna, 2003, 4, 67-84) esindavad Eesti NSV-s praktiseeritud sotsiaalselt tüpiseerivat memuaristikat.

118 Schönwälder, K. Historiker und Politik. Geschichtswissenschaft im Nationalsozialismus, 328.

119 Vt nt Stavenhagen, K. Kritische Gänge in die Volkstheorie (Abhandlungen der Herder-Gesellschaft und des Herder-Instituts zu Riga, V/7). Riga, Verlag der Akt.-Ges. "Ernst Plates", 1936, $37-47$. 
Stavenhageni 1920. aastate analüüsides Herderi "rahvaindividuaalsuse" kohta, mis oli algselt sihitud valgustajate ühekülgse ratsionalismi vastu, juttugi olla. Oma aja ühe parema Herderi-tundja väide, et Herder viis "ratsionalismivabama arusaamiseni [zu einer rationalismusfreieren Anschauung] elust, inimesest ja rahvusest", ${ }^{20}$ on ju ajalooliselt õige. Rahvapärasega "identifitseerumisel" oli nn välismaasaksluses - ka Stavenhageni "meie Herderi" pilti jaganud Wittramil ${ }^{121}$ kindlasti tegu olulise tunnetusliku seosega, "elufilosoofilise seotusega". ${ }^{122}$ Kuid olid veel mitmesugused selle seotuse üle arutlemise viisid, mis näiteks Wittramil pole üksnes argumenteerivad, vaid ka meditatsiooni, apellatsiooni jms tüüpi intellektuaalsed tegevused. Wittrami omaaegne ajuti äärmiselt poleemiline sõnastus ("anarhiliseks muutunud maailma", "kultuuri ohustava kaose" jms kohta) ei lase ka tema konservatiivse mõistet suruda meie aja poliitikateatmike lihtmääratluste raamidesse. Konservatiivne hoiak ei ole Wittramil säilitamistahe, see on korrastava printsiibi otsimine maailmas, mis just oma plaanitus liikuvuses on ahistav. Wittramile püstitas see ühelt poolt "tavaväärtuste ülekantavuse küsimuse" ja nõudis teiselt poolt "uusi vaimseid fundatsioone". ${ }^{123}$ Emotsionaalse impulsi kõrval, mida tema artiklites annab vahel edasi katke ajalaulust, dokumentaalne kirjeldus inimeste meeleolust jne, vajas ta selleks ka (kvantitatiiv)metoodilist ratsionaalset lähenemist.

Olulisimate selle perioodi tekstide analüüsi alusel ei peaks Wittramit kujutama päris ühese poliitilise otsustuse malli järgi, mis valitseb mõnede 1990. aastate autorite meeli saksa historiograafias balti ajalooteaduse ajalugu puudutaval teemal - teemal "Wittram ja rahvaajalugu". Näiteks ei vasta teaduslikule objektiivsusnõudele väide, et Wittrami käsituses "pidi" rahvaajalugu "baseeruma rassibioloogilisel huvil"124 (või tuleks neis seostes Wittrami poolt tsiteeritud Burckhardtit ka nimetada rassistiks?). Pigem vastupidi, rassi aspekt oli olemas, kuid see oli seotud etnilise aspektiga ning kujutas endast vaid üht tegurit paljufaktorilise, eri distsipliine hõlmava rahvaajaloo olemuselt uuenduslikus kontseptsioonis, nagu seda

120 Stavenhagen, K. Herder in Riga. Rede, gehalten zum Festaktus des Herder-Institutes am 4. September 1922. (Abhandlungen des Herder-Instituts zu Riga, I/1.) Riga, Verlag der Buchhandlung G. Löffler, 1925, 1-22, siin 9.

121 Herder oli baltisaksa õpetlastele kahtlemata mahukas "sümbol”, selle koosseisu kuulus ka (Stavenhageni) väide, et "herderlik Herderis" sündis just Riias. Samal ajal on huvitav, et Wittram ei ole spetsiaalselt tegelnud historismi probleemiga Herderil, kuid Stavenhagen on temast erinevalt sellele tähelepanu pööranud: "Herderil on juba 1766. aastal olnud selge, et kõigi ajalooliselt kujunenud mõttelaadide võrdõiguslikkuse tunnustamine viib või võib viia väärtusrelativismini, 'skeptitsismini'.” (Stavenhagen, K. Herders Geschichtsphilosophie und seine Geschichtsprophetie. - ZfO, 1952, 1, 20.) Põhjus on nähtavasti selles, et Wittram keskendus teisele herderlikule ideele, rahvale kui Gemeinschaft'ile, ja mõnes mõttes ka "absolutiseeris" selle oma varasel perioodil. Wittramil ei ole samuti säärast riigi-kriitikat, mille alusel mõni uurija (nt Isaiah Berlin) on võrrelnud Herderit saksa vaimuajaloos üksnes Nietzschega. Schönwälder, K. Historiker und Politik. Geschichtswissenschaft im Nationalsozialismus, 51. Vrd Wittram, R. Liberal und konservativ als Gestaltungsprinzipien baltischer Politik, 229. der Nationalsozialismus. - Zeitschrift für Geschichtswissenschaft, 1997, 1, 31. 
mõistis Wittram. "Vaimuajalugu, kultuuri-, kunsti-, kirjandus-, muusikaajalugu, ajalooline rahva- ja rassiteadus, esi- ja varaajalugu, 'poliitiline' ajalugu, sõjaajalugu, õigus- ja majandusajalugu, rahvastiku-, perekonna- ja asustusajalugu kõik peab koos toimima, et kujundada rahva ajaloolist pilti." ${ }^{125}$ Rahva ajaloolise pildi all on siin mõistetud ajaloolise identiteedi mudelit, mille kandja on ajakulus vastupidavaks peetav kultuuriline kollektiivsubjekt - (oma) rahvas. Et rahvaajalugu (Volksgeschichte) on ühekülgne võtta ainult natsiteadusena, osutab ka selle - rahvaloolise kultuuriuurimise - monograafilise käsitlemise pioneer Willi Oberkrome. "Teadlikus vastanduses [ajaloo-]eriala traditsioonilistele vormidele ja konventsioonidele määratleti rahvalugu selle esindajate poolt interdistsiplinaarse integratsiooniteadusena, milles pidid ühinema [sich verbinden] ajalugu, etnoloogia, sotsioloogia, geograafia, majandus- ja keeleteadus." ${ }^{126}$ Wittrami arusaama järgi, nii näib, on rahvalugu mõnes suhtes olnud ka herderiaanliku kulturoloogia taaslülitamine ajalooteadusse. Esineb väiteid iga rahva ajaloolist omapära rõhutavas (herderlikus) vaimus: "See, kes tunnistab end rahvaajaloo idee pooldajaks, on kaitstud kiusatuse eest sundida teistele rahvastele peale vaadet, mis talle avaneb. Igal rahval on omaenda rahvalooline pilt. Kui meil on jõudu taluda sellest tuleneda võivaid pingeid, siis on meil - eeldades meetodite puhtust - üksteiselt palju oppida." ${ }^{27}$ Nagu ta siin tsiteeritud 1936. aasta programmartiklit "Pööre rahvaajaloo poole", läbib ka mitmeid teisi artikleid "oma" ja "võõra" dihhotoomia probleem, mille ta lahendab järgmiselt: omaga korreleerub "armastuse", võõraga "mõistmise" kategooria. Tõsi küll, nende üle domineerib "ühisuse" kategooria, mille all Wittram käsitab täiesti ilmselt seda, mis on saksalik (mitte: "germaanlik"). Rahvaajaloo algmed saksa vaimuajaloos viis Wittram tagasi 1790. aastaisse, Herderi ja Schlözeri juurde, rahvaajaloo-uurimise taassünnis nägi ta aga esiteks "rahvusriikliku ja väikesaksa ajaloopildi", teiseks "provintsiaalse vaatlusviisi"

125 Wittram, R. Die Wendung zur Volksgeschichte, 568. - Mitte ainult natsismiseotus, vaid üldse rahvusideoloogiliste aspektide tihe põimumine ajalookäsitlusega võib olla ka põhjus, miks 1970.-80. aastate levinumad ajalooleksikonid (nt Fuchs/Raab) ei sisalda märksõna "rahvaajalugu" ja esitlevad mõne rahvalooliste uuringutega seotud prominentse sotsioloogi (nt kas või baltlase M. H. Boehmi ja tema partneri H. Freyeri) tööd märksõna "rahvas" all. Rahvaajaloo kui teaduslikult innovatiivse suuna puhul, mida võib lugeda "struktuurajaloo eelkäijaks" XX sajandi 2. poole ajalooteaduses, muutus uurimissituatsioon 1990. aastaist. Vt eelkõige Oberkrome, W. Reformansätze in der deutschen Geschichtswissenschaft der Zwischenkriegszeit. - Nationalsozialismus und Modernisierung. Hrsg. von M. Prinz und R. Zitelmann. Darmstadt, Wissenschaftliche Buchgesellschaft, 1991, 216-238; vrd ka: Oberkrome, W. Aspekte der deutschsprachigen "Volksgeschichte" (1992/95). - Zwischen Konfrontation und Kompromiss, 37-46. (Oberkrome Volksgeschichte-dissertatsioon ilmus raamatuna 1993 Göttingenis [Vandenhoeck \& Ruprecht].) Wittrami II maailmasõja järgsete ümberorienteeringute kohta vt Neitmann, K. Reinhard Wittram und der Wiederbeginn der baltischen historischen Studien in Göttingen nach 1945. - Nordost-Archiv. Zeitschrift für Regionalgeschichte, NF, 1998, VII/1, 11-32, eriti $25 \mathrm{jj}$.

126 Oberkrome, W. Reformansätze in der deutschen Geschichtswissenschaft der Zwischenkriegszeit, 227.

127 Wittram, R. Die Wendung zur Volksgeschichte, 568. 
ületamist. ${ }^{128}$ Need olid ka Nietzsche kriitikaobjekt, aga viimase mõjuga Wittramile selles küsimuses vaevalt et tegu on. Ajaloolis-poliitiline olukord maailmas pani Wittramit vaatama oma rahvusvähemusele Baltimail mitte ainult kui kohalikule rahvagrupile, vaid ka kui "välissaksluse" killule (Volkssplitter), osale mittekohalikust tervikust - saksa "tervikrahvast" (Gesamtvolk). Rahva ajaloolis-geneetiline mõiste, mis oli traditsioonilise historismi arusaamade kohaselt diferentseeritud, suubus lõpuks organitsistlikult mõistetud riigiülesesse "kõiksaksa" rahvakehandisse. See käsitus on selgelt rahvussotsialistlik, aga kui vaadata täpsemalt, siis ei ole selle dominant üldse naturalistlik (rassibioloogiline), vaid puhtalt kultuuriline (rahvakultuuriline). Wittrami silmis on rahvalikkus midagi eksistentsi võimaldava algaluse sarnast, mis seob kõiki primaarselt ja normatiivselt, maailmavaatelise juhtnöörina oleks see oma sotsiaalses väljundis peamine integreeriv jõud, mis suudaks ületada - esmajoones baltisakslaste - ühiskondliku killustumuse seisundi ("taas siduv kord"). Tegemist on rahvalikkuse metafüïsikal põhineva konservatiivse utoopiaga, seda esitavais autoritekstides, kus Wittramil diagnoos vaheldub soovmõtetega, ei puudu ka olukorra tõsidusele viitavad - religioosse värvinguga - manitsemise jooned. Oma balti rahvagrupi individuaalse ajaloolise käekäigu interpreteerijana kuulub Wittram rahvussotsialismi ja rahvaajaloo ajastuseosesse. Et tegu on ajastuseosega, siis võib samuti öelda, et rahvaajalugu oli ajaloouurimise suunana konjunktuurne ja ideoloogiliselt toonase ajavaimuga sobituv või ühituv. Kuid väide, nagu olnuks "rassistlik atitüüd" Wittrami viljeldud rahvaloole "alates 1933. aastast määrav" või et see moodustavat kogu rahvauurimise "poliitilise brisantsi", ${ }^{129}$ on teaduslikult ebakorrektne. Niisuguste väidetega, mis bioloogilisuse arvestamist rahvaajaloo käsitlemisel taunides lähenevad juba vulgaarse sotsiologismi hoiakule, ${ }^{130}$ sisendab autor Hans-Erich Volkmann lugejale vääralt üldistava mõtte, et Wittrami ajalookäsitus oli oma eesmärgilt ja teostuselt

128 Wittram, R. Die Wendung zur Volksgeschichte, 568.

129 Volkmann, H.-E. Von Johannes Haller zu Reinhard Wittram, 30. - Ebakorrektsus tuleneb antud juhul eksimisest üldteadusliku metoodilise põhimõtte (nn relevantsuse printsiibi) vastu: see nõuab uurijalt, et kasutada tuleb kõiki teatud küsimuse kohta olulist teavet sisaldavaid allikaid. Lisaks sellele peaks uurija Wittrami-taolise silmaringiga autori puhul arvestama tekstidevahelisi suhteid (s.o intertekstuaalseid momente): need heidavad tema seisukohtadele täiendavat valgust, muutes talle antava hinnangu arusaadavamaks või ka tähendusrikkamaks. Ideepoliitilisse "sõiduvette" tüürivat (mõnevõrra "tendentslikku") ja metodoloogilisel veal rajanevat lähiajaloolist otsustust ei saa - rangelt võttes - lugeda enam piisavaks ajalooteaduslikuks tulemuseks ka historiograafilis-kontekstuaalsetel kaalutlustel: Wittrami-retseptsioonis on kaua aega domineerinud poliitiline aspekt tema loomingu muude aspektide uurimise kahjuks. Korrektne ajalooteaduslik Wittrami-kriitika (H.-E. Volkmanni poolt vaatluse alla võetud küsimuses) peab lähtuma Wittrami "rahva"-mõistest ning jälgima selle dünaamikat (1930-ndate algusest 1970-ndate alguseni). Põhjenduseks võib siin tuua kaaluka asjaolu, et Wittramil peitub selle mõiste taga tänini oluline - sotsiaalfilosoofiline probleem: inimeste solidaarsuse küsimus nende ühisena tunnetatud mineviku alusel.

130 Vrd "Inimesekäsituses avaldub v[ulgaarne] s[otsiologism] inimese bioloogilise loomuse tähtsuse ignoreerimisena." (Filosoofia leksikon. [Tlk I. Gräzin jt] Tallinn, Eesti Raamat, 1985, 355.) 
(natsismi doktriini tähenduses) rassipoliitiline, tähendab, rassipoliitikat ajav pseudoteadus.

Praktiliselt kõikjal, ja neid tekstikohti on üsna palju, kus Wittramil võib ära tunda poliitilist kõnelemist rahvussotsialismile sarnases terminoloogias, on harva tegu mingi parteikeelse "rasside võitluse" verise temaatika alla mahtuva või rassiprintsiipi üheselt forsseeriva käsitlusega. Nii näiteks ei saa midagi selletaolist inkrimineerida Wittrami rahvaloolise kontseptsiooni alusel kirjutatud üldkäsitlusele - "Balti sakslaste ajaloole" (1939). See teos kui näide peaks olema ka poliitilisele Wittrami-kriitikale representatiivne, tegemist on Wittrami "rahvaajaloo idee" esmase ajalookirjutusliku teostusega. Töö teoreetilisi eeldusi põgusalt käsitlevast "Eessõnast" (august 1938) joonistub välja idee, et rahvalugu on historismiga toimetulemist püüdlev, ajaloolist relativismi neutraliseerida üritav ja mitte rassistlik kontsept. "Me tahame minevikult teada, kuidas oleme kujunenud. Enam kui süüvimine ajastutesse on meile vajaduseks arengujoonte tunnetus. [...] Iga katse suuri ajavahemikke rahvalooliselt üle vaadata on ajaloolise muutumise ammendamatu probleemi ees [steht vor dem unausschöpfbaren Problem der geschichtlichen Wandlung]. Kõrgkeskaja, valgustusaja, rahvusepohhi inimene kas ülevaatamatut sugupõlvedeahelat tuleb võtta ühtsusena [als Einheit], haarata kui üht suurt kulgu? Me arvame: jah. Sest kogu epohhide muutuses elab loovalt, saladuslik-võimsalt toimiv jõud, rahva südamelöök." ${ }^{131}$ Ühtsuse tagamine ajalises muutuvuses, püsivale taandumine aegade erinevuses, kindla niidi leidmine suhtelises ilmas - see on rahvaloo historismi ohjeldav funktsioon ja sel pole otseselt pistmist rassivõitlusega. "Balti sakslaste ajaloo" eelviimases peatükis, milles võetakse üles üks Wittrami poliitiline meelisteema, baltisaksluse "atomiseerumise" põhjustatus liberalismist, libisetakse baltlaste "suhtumisest juudiküsimusse" "132 üle vaevalt poole lehekülje ulatuses. Sellega - rassismiga - pole tegemist isegi anonüümses, Wittramile omistatavas lühiartiklis "Juutide ajaloost Baltikumis" (märts 1934), kus see võiks olla enim rassiideoloogiliselt ootuspärane. Tegelikult antakse seal hoopis kiretu ajalooline ülevaade juutide sotsiaalsest ja õiguslikust kohtlemisest Balti- ja Põhjamaades ning alles lõpulause ütleb, et pärast 1930. aasta rahvaloendust olevat suhtumine Lätimaa juutkonda tuntavalt muutunud: "Loomuliku võõruse tunne, rassiline teadvus, tärkab ka meie läti kaasmaalaste hulgas." "133 Rassilisus ja pärilikkus on Wittramile "antused" (Gegebenheiten), need kuuluvad tema tekstides "looduslike eelduste maailma", mitte primaarselt rahvaste maailma, millel on ainsana "poliitiline loomus". 1930-ndate lõpu teoreetilised seisukohad jätavad Wittramist mulje, et bioloogilise ehk "eluseadusliku" alge tähtsustamine ("ankurdumine bioloogilisse") väljendab tal ajaloolis-sotsiaalse liitumist bioloogilisele. Wittram ei alluta ajaloolist puhtalt bioloogilisele, ta väidab, et neid poolusi ei ole õige üksteisest isoleerida: ajaloolane peab neid võtma "seotuna",

131 Wittram, R. Geschichte der baltischen Deutschen. Grundzüge und Durchblicke. Stuttgart u. Berlin, Verlag von W. Kohlhammer, 1939, IV.

132 Vt samas, 174-175.

133 [Wittram, R.] Zur Geschichte der Juden im Baltikum. - BMH, 1934, 3, 173-175, tsitaat 175. 
"liidendatuna" kõigi inimeste "looduse eluringi" kuulumise fakti alusel. ${ }^{134}$ Wittrami väljenduslaadile on selles suhtes üldiseloomulik kas või selline rahvussotsialistliku maneeri näide (1936. aastast): "Me oleme teadlikud vajadusest rassilisbioloogilisi, vaimseid-hingelisi protsesse rahvaajaloo peatükina [Hauptstück] näha, ja mitte kunagi enam ei või me rahva tüvikihte [Mutterschichten], iseäranis maaelulisi [bäuerliche], tähele panemata jätta."135 Võttes arvesse, et "tänases keelepruugis on mõiste 'rass' ja selle tuletis 'rassism' tavaliselt samatähenduslikud diskrimineerimisega", ent "algselt oli rass siiski täiesti neutraalne mõiste ja [...] sel puudusid ka avalikult alavääristavad konnotatsioonid", mis tekkisid sõna kasutamisel "võitluses ühe vähemuse - juutide - vastu", ${ }^{136}$ siis on küsitav selle mõiste seostamine Wittrami pruugis ainult halvustava kõrvaltähendusega. Kas aga ei tuleks siin Wittrami arvatava rassismimeelsuse asemel esmalt märgata ta rahvaajaloo mõiste silmatorkavalt industrialismivastast suunitlust, opositsiooni "tööstusrahva" kontseptsioonile?

Minu arvates hoidis Wittramit natsionaalsotsialistliku rassipoliitika madaluste eest tema vaieldamatult kõrge professionaalne tase ajaloolasena. Arvamust toetab ka oluline fakt, et ajalooline identiteet, mille probleeme Wittram küllalt sageli kirjeldab, on tema pilgu läbi kompleksne suurus. Seetõttu, nagu tundub, ei saanud Wittramist näiteks Walter Franki sugust Uue Saksamaa "võitleva teaduse" karjääriajaloolast ega natsionaalsotsialismi õuehistoriograafi. 1945. aastal enesetapu sooritanud antisemiit Frank käsitles (1937. aasta töös "Ajalugu ja elu”) ka Nietzsche suhet historismiga nii bukvaalselt, et tahtis "teha lõpu" ajaloolise väärtusega dokumentide publitseerimisele ehk "õpetatud impotentsile"137 (vrd HL 5). "Nietzscheliku" ideena absurdne, olnuks see teadusevaenulik avantüür iga Wittramitaolise ajaloolase meelest võimatu.

Reinhard Wittrami ülalmainitud ajastuseose väga ilmekas ja isegi dramaatiline kokkuvõte, ka ajalookirjutuslik illustratsioon programmilisele teesile "rahvakuuluvus omab saatuseiseloomu", ${ }^{38}$ on koos pühendusega Läti rahvussotsialistide liidrile tema 1940. aastate "Liivimaa"-raamat, mille viimastel lehekülgedel kõlab baltlaste 1920. aastate kultuurialgatuste kirjeldamisel elu ja teaduse "teenimis"vahekorra tüüpiliselt nietzschelik motiiv (Nietzschet mainimata). ${ }^{139}$ Palju räägitud, kuid peale suusõnalise legendi mitte millegagi kinnitatud jutu kohaselt olevat ta seda väiketeost (trükiarvuga 5000 eksemplari) pärast sõda, mil nii ägedalt kõneldi "Nietzschest Hitlerini" viinud saksa teest, püüdnud käibelt kõrvaldada. 1980. aastate algul (dateerimata kujul) trükki pääsenud käsikirjaline märge kõneleb

134 Vt nt Wittram, R. Historismus und Geschichtsbewusstsein, 559.

135

136 
Wittrami petetuse-tundest: “'Liivimaa'-teos on kirjutatud vajadusest luua ümberasunud baltisaksa rahvagrupile poliitiline alibi. [...] Selle täielik valestimõistmine, mis natsionaalsotsialism oli ja mis tema taga seisis, on raamatu fundamentaalne eksimus." 140

Uuema aja, 1990. aastate Wittrami-kriitika on valdavalt olnud poliitiline, mitte filosoofiline, ja selliselt - kriitika suuna või teema mõttes - on Wittramit arvustavate ajaloolaste historiograafiline tegevus olnud ka traditsiooniline. Kriitika traditsioon on määranud kriitikute arutlusraamid, selle, mis kõne alla võetakse, ja sellegi, mismoodi vastavat kõneteemat arendatakse. Nõnda omandab kriitikatraditsioon teatud küsimusi elimineeriva iseloomu, mis ei tule "Wittrami juhtumi" uurimisele kasuks. Ajaloolase maailmapilt pressitakse juhtumi sisse, tema "fundamentaalsest eksimusest" saab nii tema igavene Prokrustese säng. Säärase tegevuse, antud juhul balti ajaloolase isiku kallal, võib nimetada ümber negatiivse identiteedi loomiseks. Aga on kahtlane, kas seda sorti poliitiline sotsioloogia on Wittramile rakendatuna ühitatav ajalookirjutuse humanitaarsete eesmärkidega. Wittrami isiklik, niihästi oma rahvagrupi kui ka teiste rahvaste ajaloolis-põlvkondlik draama poliitiliste süsteemide heitluses maailmavõimu pärast kõlab 1950. aastail vastu ühes tema uues temaatilises refleksioonis. Need on massivägivalla ajastu teadlasele peaaegu vältimatud sisemõtlused ohvri probleemi üle ajaloos. Kuid selleski eetilise tähendusega refleksioonis on säilinud 1930. aastate historismiarutluse ammune leitmotiiv (Nietzsche Gewesensein'i ümbrusest) (HL 1): mineviku "nii-ja-mitte-teisiti"-olekust, ajaloo möödunud osast kui "surnutelinnast", ajaloolisest elust "surma poole" jne. Loogiline on, et XX-XXI sajandi vahetuse nn uus ajaloofilosoofia leiab talt toetuspunkte " "teise' surelikkuse" fenomenoloogiliseks analüüsiks ja on "presentistliku identiteedi-kontseptsiooni" kritiseerimisel avastanud Wittramis endale mõttekaaslase. ${ }^{141}$

\section{NIETZSCHE KUTSEAJALOOLASTE HORISONDIL Nietzsche ja ajaloohävituse ettekujutused}

Elutahte kategooria toomine ajaloomõtlemisse seostub kutseliste ajaloolaste kujutluses sageli minevikukohaste hoiakute allutamisega olevikuelu vajadustele või paratamatusele, nii modernsuse noorusekultusega kui XX sajandi "ajaloohävitusega" (Geschichtszerstörung), mis on kas teadlik lammutamine või tahtmatu purustamine. Thomas E. Fischer on näiteks alles 2000. aastal oma kontseptuaalselt uuenduslikus "Ajalookultuuri ajaloos" märkinud: "Moodne inimene näiliselt ei vajanud enam vana, vananenut, ta oli sõltumatu ja automobiilne. Mida tähendas talle möödunu? Mis on siis, nõnda küsis Friedrich Nietzsche 1874, "ajaloo

140 Tsit artiklist Volkmann, H.-E. Zur Ansiedlung der Deutschbalten im "Warthegau". - ZfO, 1981, 4, 556.

141 Vt Liebsch, B. Geschichte als Antwort und Versprechen. Freiburg/München, Verlag Karl Alber, 1999, 271 ja 299. 
kasu ja kahju elule"? Küsimuse püstitamine tähendas ühtlasi sellele vastamist: seega kahju. Ajaloo haridusväärtust, millest oli kogu aeg nii palju juttu, paljud enam ei tunnustanud. Filosoofid nagu Henri Bergson ja Hermann Keyserling ning kirjanikud nagu Frank Wedekind ja Hermann Hesse rõhutasid pigem 'elu' suveräänsust." ${ }^{142}$ Sellised väited on tegelikult paljuski küsitavad, veel enam, elufilosoofia suhtes üldse ja nn elufilosoofilise ajaloofilosoofia suhtes eriti on nad ka otseselt desorienteerivad. Probleemiks ei olnud mitte lihtsalt möödunu kui vananenu tähendus lineaarses ajakulus, vaid ajaloolise tähendus inimese kultuurile, tema "elukujundusele" (Lebensgestaltung), nagu XX sajandi algupoolel öeldi iseenda vormimisele, endale kuju andmisele. Minu arvates on elufilosoofial ka seetõttu olemas uusimal ajal kahjuks liigagi sageli alahinnatud humanistlik aspekt.

Elufilosoofia kui mõttevoolu esindajad liigitasid "ajaloo" moodsas kultuuris esmakordselt ja rõhutatult "inimelu probleemide" hulka. Selles on võimalik veenduda Nietzsche kaasaegse filosoofi ja kirjaniku Rudolf Euckeni (1846-1926) korduvates ümbertöötustes ja uustrükkides ilmunud "kaasaja põhimõistete" ulatusliku käsitluse põhjal, mis esitab ka "modernse/moodsa" ajalooliselt kompetentse mõisteanalüüsi. ${ }^{143}$ Üldjuhul, ka tänapäeva ajaloolaste poolt irratsionalistina kujutatud Theodor Lessing (1872-1933) püstitas oma ajalookäsitluses "inimkonna mälu" probleemi, ta väitis mälu "läbinisti aktiivselt loovat" iseloomu nii teadliku kui teadvustamata protsessina ja uuris ajaloomälu funktsioone (kolmel tegevuslikul tasandil) umbes 60 aastat enne mäluhuvi plahvatust nüüdisaegsetes kultuuriteadustes. ${ }^{144}$ Keyserling osutas faktiliselt ajaloo kultuuritüpoloogiliselt erinevale toimele ja tähendusele inimgruppide elus. Nii mõnedki Schopenhaueri Hegelikriitika tuntavate mõjudega ja Nietzschele lähedaste küsimuseasetustega ajalooteemalised tekstid - nt eriti "Ajaloo huvist" (1911) või ka "Ajalugu kui tragöödia" (1924) - näitavad selgelt, et ta mõtles elust ja ajaloost väga seostatult. Õieti mõtles ta neist nende ühtsuses, sest tema käsituses teostub inimelu ajaloos. Elu suveräänsuse all pidas ta aga silmas ka seda, et maailmavaade ei saa olla "ebaisikuline", sest siis ta oleks "mitteinimlik" ega saaks "inimesele kõnelda" ${ }^{145}$ ei oleks dialoogiline. Ühtlasi püstitas Keyserling küsimuse ajaloohuvi väärtusest ning analüüsis seda põhjalikult. Mis puutub ajalooalasesse haridusse, siis I maailmasõja eel välja antud ajakirjale "Minevik ja Olevik" kirjutas ta spetsiaalse - fenomenoloogiliste sugemetega - artikli tänapäevalgi diskuteeritavas küsimuses, kas ajalooõpetus peab olema rahvuslik või mitte. Vastavalt oma ajalookäsituse põhimõtetele, millel me siin rohkem ei peatu, suhtus Keyserling ka Nietzschesse: “... Mida

142 Fischer, E. Th. Geschichte der Geschichtskultur. Über den öffentlichen Gebrauch der Vergangenheit von den antiken Hochkulturen bis zur Gegenwart (Bibliothek Wissenschaft und Politik, 57). Köln, Verlag Wissenschaft und Politik, 2000, 157.

Vt Eucken, R. Geistige Strömungen der Gegenwart. Der Grundbegriffe der Gegenwart 5. umgearb. Aufl. Leipzig, Verlag von Veit \& Comp., 1916, eriti 243-271.

144 Vt Lessing, Th. Geschichte als Sinngebung des Sinnlosen oder Die Geburt der Geschichte aus dem Mythos. 4., völlig umgearb. Aufl. Leipzig, Verlag Emmanuel Reinicke, 1927, 96-104. Darmstadt, Otto Reichl Verlag, 1920, eriti 6 jj. 
Nietzsche tähendab, jah, kes ta tegelikult oli, selle üle võivad otsustada alles meie lapselapsed." 146

Dialoog elu(filosoofia) ja ajaloo(teaduse) vahel on see, millest on kaua aega mööda vaadatud: Nietzsche erakordselt suurest mõjust nüüdisaegse kultuuri, ${ }^{147}$ sh mõtte-, kunsti- ja teaduskultuuri eri valdkondadele näib esimesel pilgul olevat ainult üks silmatorkav erand - teaduslik ajalugu. Nietzsche oli XX sajandi esimesel poolel ajaloolastele teatud "sümptom" XIX sajandi lõpul tekkinud "uuest lõhest kirjanduse ja teaduse vahel", nagu märkis Meinecke, seda lõhestumust süvendas teadustaotlus, ajaloo muutmine "üha enam ja enam eriteaduseks". ${ }^{148}$ Kutseliste ajaloolaste panus ka Nietzsche 2. "ajakohatut vaatlust" käsitlevasse sekundaarkirjandusse on sajandiga üllatavalt väike, teiste humanitaarsete erialadega võrreldes (klassikaline filoloogia, filosoofia mõned suunad, kunsti- ja kirjandusteadus) seda peaaegu ei olegi.

Mitte vähem silmatorkav pole see, et autoreile, kes kaitsevad ajaloouurimises teadusliku ratsionaalsuse õigusi, kuid ei pea nende õigustega võrdväärseks selle-

146 Keyserling, H. G. Vom Interesse der Geschichte (1911). - Ders., Philosophie als Kunst, 174.

147 Vt nt Gerhardt, V. Hundert Jahre nach Zarathustra. Zur philosophischen Aktualität Nietzsches (1984/88). - Ders., Pathos und Distanz, 188-216; Behler, E. Nietzsche in the Twentieth Century. - The Cambridge Companion to Nietzsche. Ed. by B. Magnus and K. M. Higgins. Cambridge, Cambridge University Press, 1999, 281-322; Vizgin, V. P. Filosofiya Nitsshe v sumerkah nashego segodnja. - Idem, Na puti k drugomu. Ot shkoly podozreniya k filosofii doveriya. Moskva, Jazyki slavjanskoj kultury, 2004, 307-341.

148 Meinecke, Fr. Über Spenglers Geschichtsbetrachtung (1923). - Ders., Zur Theorie und Philosophie der Geschichte, 183. Meinecke on samas, väljaandja Eberhard Kesseli poolt Meinecke arhiivist leitud käsikirjaliste märkuste järgi, Nietzschega seoses tähendanud: "Üleüldse lahkneb vaimne maailm sellisteks, kes Nietzschet seedivad [die Nietzsche im Magen haben], ja sellisteks, kes Nietzschet ei seedi." Konteksti põhjal võib järeldada, et nende viimaste hulka, kes "Nietzschet ei seedi" ja on ühtlasi sunnitud taluma "etteheiteid historismile", kuuluvad ka tavainimeste ajaloohuvi rahuldavaist "uljastest diletantidest" - Chamberlain, Lamprecht, Sombart (!) - eristatud professionaalsed ajaloolased. Väärib märkimist, et samal ajal esineb sama motiiv nn absoluutse historismi teoreetikul Crocel, kes historismi küsimuses oli Meineckest küllalt erinevail seisukohtadel: ka tema arvas, et "diletantide" ja "pseudoõpetlaste" - Chamberlaini, Ferrero, Spengleri - esiletõus "peab valmistama tõsiselt muret neile, kellel on südamel teadusliku töö saatus" (Croce, B. Oswald Spengler, Der Untergang des Abendlandes (1920). - Ders., Randbemerkungen eines Philosophen zum Weltkriege. Zürich/Leipzig/Wien, Amalthea-Verlag, 1922, 293 jj). - Jääb mulje, et kumbki neist suurtest ajaloolastest, ei Meinecke ega Croce tajunud veel, ja seda mittearusaamist tuleb ette tänapäevalgi, et ajalooteadmise relativeerumine tekitab tõsiteaduse kõrvale vältimatult ajaloofilosoofilise konstruktsiooni ja spekulatsiooni. Seega: probleemne ajalooteadus ei tee ajaloofilosoofiale lõppu, nagu varem usuti, vaid otse vastupidi, ta ise ajendab ja kutsub seda esile. Historismi kriis teaduses (ajalooline relativism) tingib ka uue vajaduse ülevaatlikuma ajaloofilosoofia järele, mida rahuldavad nt Spengleri ja Toynbee' tüüpi ajaloovaatlused nüüdisajalgi. Gunter Scholtzi järgi - kes on seda olukorda umbes samuti mõistnud - relativistlik historism isegi "nõuab" (fordert) ja "toodab" (erzeugt) ajaloofilosoofiat: nimelt "kui tõlgendushüpoteesi ajalooliste seoste jaoks ning oleviku kohamääratluseks" (Scholtz, G. Das Historismusproblem und die Geisteswissenschaften im 20. Jahrhundert (1989/91). - Ders., Zwischen Wissenschaftsanspruch und Orientierungsbedürfnis. Zu Grundlage und Wandel der Geisteswissenschaften. Frankfurt a. M., Suhrkamp Taschenbuch Verlag, 1991, 146). 
sama ratsionaalsuse esteetilisi aspekte, on Nietzsche "irratsionalist", mitte hermeneutik, kes ta on palju rohkem või sõltuvalt teosest isegi ennekõike. Nietzsche positsioon, et "ei inimene ega tema tunnetusvõime või maailm pole midagi 'samaksjäävat' sealpool ajalugu", laseb ühtlasi näha, et ta kavandas "metafüüsilise" mõtlemise vastu suunatud "histoorilise" filosoofia, mis "analüüsib filosoofilisi probleemiseadeid kui vitaalsete eluprotsesside tulemusi". ${ }^{149}$ Sellest järgneb, et Nietzsche kohaselt pole meil õigust taandada asju vaid ühele mõistuse antud tõlgendusele ja pidada siis seda tõlgendust maailmas ainsana võimalikuks. Nietzsche on - vähemalt printsiibilt - ühetaolise ja masinliku mõistuserakenduse vastane, olgu see või teaduslik. Vaidlus Nietzschega, näiteks positivistlikult meelestatud ajaloolasel, ei saakski tekkida enne, kui Nietzsche on tunnistatud hermeneutikuks, sest tema nüïd sotsiaalteadustes lendlausena ringlev väide, et "fakte pole olemas" (täpsemalt: pole "iseeneses" [ "an sich"] olemas), tuleb sellest, et Nietzsche universaliseerib tõlgendusmõiste. Sellega muutub tõlgendamine eluprotsessile põhiliseks ja olemuslikuks, ajaloolist elu kandvaks tegevuseks. Kriitika ammune vastuväide, et "elu tuleb teatud määral 'surmata', jõudmaks omaväärtustega kultuurieluni", ${ }^{150}$ näitab muide, kuivõrd seda Nietzsche elufilosoofias tõlgendusele omistatud universaalset rolli (kuni varase Heideggerini) ei mõistetud. Nietzsche asend historismi kontekstis on selle mittemõistmise tagajärjel jäänud ka ajaloolaste silmis oma "ratsionaalsust" tema "biologismile" vastandava üldhoiaku tasemele.

Just see elufilosoofia kriitikute poolt - Rickertist Lukácsini - mitteiseseisvana, "Schopenhauerist otseses sõltuvuses"151 olevana või ka "Schopenhaueri ja Nietzsche koolkonna" 152 osapoolena nähtud Nietzsche, biologisti, irratsionalisti, voluntaristina iseloomustatav Nietzsche (võib öelda: Nietzsche antimüüt) figureerib historismiajaloo "antihistoristliku" ääremärkusena. Ajaloolise mõistuse kriitikust, kelle olulisemateks probleemideks olid, esiteks, elu ja ajaloo vahelise tasakaalu leidmine ning, teiseks, õigluse kui suhtelise kategooria vahekord teadusliku objektiivsusega, saab nii üsna robustne ajaloovastane. Kummaline küll, aga tema väidetavalt sama antihistoristlik kaaslane on seda laadi ääremärkustes ka Nietzsche ajaloovaate peene tajuga interpreet Spengler. Viimase poolt nüüd juba üle 80 aasta tagasi oma vaadete kaitseks kirjutatud väiketeos "Pessimism?", mis autorimõtte järgi sisaldab Nietzsche motiivide arendusi ja seab ajalooteaduse ette küsimused: "Mida tähendab sõna 'aeg'? Sellele pole olemas teaduslikku vastust.

149 Scholtz, G. Hermeneutische Philosophie. - Philosophie in der Geschichte ihres Begriffs. Historisches Wörterbuch der Philosophie. Sonderdruck, hrsg. von K. Gründer. Basel, Schwabe \& Co. AG Verlag, 1990, 754.

150 Rickert, H. Die Philosophie des Lebens. Darstellung und Kritik der philosophischen Modeströmungen unserer Zeit. 2., unveränd. Aufl. Tübingen, Verlag von J. C. B. Mohr (Paul Siebeck), 1922, 156.

151 Samas, 19.

152 Lukács, G. Über Preussentum (1943). - Ders., Schriften zur Ideologie und Politik (Werkauswahl, 2). Ausgew. und eingel. von P. Ludz. (Soziologische Texte, 51.) Neuwied u. Berlin, Hermann Luchterhand Verlag, 1967, 347. 
Mida tähendab sõna 'ruum'? See on teoreetilise järelemõtlemise võimalik ülesanne", ${ }^{153}$ on ka historismi relativistliku staadiumi säravamaid analüüse XX sajandi esimese poole ajaloomõtlemises. Spengleril oli õigus, kui ta 1922. aastal kirjutas: "Küsimuse teaduse väärtusest püstitas Nietzsche."154 Teaduslik ajalugu on (poliitilistel motiividel) jätnud mõlemad liigagi sageli endast väljapoole, eriti siis, kui Nietzschet ja Spenglerit on kujutatud antihumanismi "teerajajatena". Periooditi (nt katoliikliku ajaloolase Alfred von Martini tööd 1940-ndate lõpu LääneSaksamaal, marksistliku sotsioloogi Juri Davõdovi omad 1980-ndate alguse Nõukogude Liidus) ei näita see niivõrd autorite pädematust kui ideoloogiliste kahtlustuste funktsionaalset osatähtsust ajalookultuuri kujundamisel, ühiskondade ajaloopoliitikat.

Nietzsche suhtes imperiaalselt rakendatud, ametlikustatud ajaloopoliitikal, mis valitses muidugi ka nn Nõukogude Baltikumis, on aga ajaloolase kutsele oma erilise mündiga tagasipeegeldus. XIX sajandi lõpupoole "historistide" plejaadist, kui jätta siinkohal välja Marxi mõned esindustekstid (!), pole vahest mitte kedagi teist peale Nietzsche, kelle arutlusi läbiks siin-seal nii järjekindlalt mõte, et ajaloo käsitlemise kaudu teostatakse inimeste keskel pidevalt sotsiaalset ja poliitilist võimu. Nõnda võib nietzschelikus laadis öelda, et teaduslikul ratsionaalsusel ei ole ainult "õigused", vaid tal on ees ka "maskid", millega peidetakse tema igakordset võimuloomust. Kas selle instrumentaalse seose kaudu ei hoita ühtedes või teistes oludes (Nietzsche väljendiga: "ühiskondlikes kombinatsioonides"), sealhulgas koolitatud ekspertide enda käe läbi, enesekaitseks käigus ajaloohävituse protsesse? Ajaloo dikteeritud ümberkirjutamine - kas pole see teatud psühholoogilistel eeldustel ja eriti sotsiaalpoliitilistel tingimustel ühe kollektiivajaloo hävitamine teisega?

Erineva suunitluse ja tasemega ajaloolasi XX sajandi teisel poolel mõjutanud ning uuematesse ajalooleksikonidesse võetud autorina on vaid Michel Foucault end avalikult "nietzscheaaniks" tunnistanud. Tuntud ajaloolaste-teoreetikute hulgast on oma positiivse suhtumisega Nietzschesse ka "metaajaloolane" Hayden White pigem erand kui reegel. 1920. aastal Friedrich Würzbachi (1886-1961) asutatud Nietzsche Seltsi eestseisusse kuulus peale maailmatuntusega kirjanike (H. v. Hofmannsthali ja Th. Manni) siiski ka üks väga nimekas ajaloolane, Heinrich Wölfflin, tõsi küll, mitte "päris-", vaid kunstiajaloolane, kes n-ö nietzschelikus kontekstis esineb pigem Burckhardti teoste väljaandjana. Teadmine, et moodsa sotsiaalteaduse suurkuju Max Weberi maailmapilti, teadusekäsitust ja isegi stiili nii uurija kui metodoloogina on otsustavalt mõjutanud Nietzsche, oli ajaloolastel üldjoontes olemas juba 1960-ndate keskel, ${ }^{155}$ ent jõudis detailselt põhjendatuna

153 Spengler, O. Pessimismus? (Schriftenreihe der Preussischen Jahrbücher, 4.) Berlin, Verlag von Georg Stilke, 1922, 7.

154 Samas, 17.

155 Vt Mommsen, W. Universalgeschichtliches und politisches Denken [bei Max Weber] (1965). - Ders., Max Weber. Gesellschaft, Politik und Geschichte. 2. Aufl. Frankfurt a. M., Suhrkamp Taschenbuch Verlag, 1982, 107-108, 254-255. 
laiema avalikkuse ette alles suhteliselt hiljuti - 1986. aastal. ${ }^{156}$ Eesti stalinismijärgses ajalookäsitluses välistasid igasuguse kontakti Nietzschega juba uurimisprioriteedid, rääkimata sellise imaginaarse kontakti antimarksistlikust loomusest "leninlikul etapil", ainult mõni saksa ekspressionismi taustaga vabauurijast kirjandusloolane (nt Nigol Andresen) hoidis oma tekstides alal autonoomse suhtumise Nietzschesse. Okupeeritud Eestis on küll avaldatud (läti autori poolt vene keeles) käsitlus XX sajandi ühe arvestatavama Nietzsche-interpreedi Karl Löwithi "ajaloofilosoofilisest kontseptsioonist", ${ }^{157}$ kuid seal esitatud koguni veidrad seisukohad ei suuda ületada sovetiseeritud ülikooliteaduse reglemendi piire. Sovetism asetas oma teadusemudelis kõikjal Nietzsche tõlgenduse asemele Marxi autoriteedi, teadustöötajate kohandumine poliitilisele "võimutahtele", mille üheks avalduseks oli ka parteiline liikmelisus, tegi neile võimatuks adekvaatse interpretatsiooni. Enamluse ideoloogialoo üks huvitav nähtus, "marksistlik nietzscheanism" (Anatoli Lunatšarski jt), ${ }^{158}$ näib olevat meil 1970. aastail köitnud ainult kirjanduse ja esteetilise kultuuri uurijaid, mitte filosoofe, sotsiolooge ja ajaloolasi. Wittrami mineviku arvustajad, kes näevad heroismiga liialdamist natsismi keeles, on maailmavaateliselt ühekülgsed, sest nad ei teadvusta Nietzsche-mõjulise heroismi allüüre nõukogude marksismi keeles, selle üks allikaid oli (mõneks ajaks) poliitilisse juhtkonda või ka lähikonda tõusnud "marksistlike" nietzscheaanide propagandakeel. Karakteerne on, et oma mõtlemises Nietzsche ja Marxi ideid sünteesinud uusmarksistlik teoreetik Max Horkheimer, kes 1937. aastal pagulusest arvustas muu hulgas rahvussotsialistide "pidevat kõnelemist" heroismist, "seda ühelt poolt suurtsugust, teiselt poolt rahvapärast stiili", ${ }^{159}$ jäi tollal selles küsimuses veel olupoliitika tasemele. Hiljem, 1950. aastal, osutas ta Nietzsche ideoloogilise vääritimõistmise põhjusena lingvistilisele küljele - Nietzsche "keelega mängimise" tõttu tema keele mittemõistmisele (Ameerikas ja Nõukogude Venemaal). "Eeter, milles Nietzsche mõtlemine liigub, on raskesti mõistetav, nagu ta

156 Vt Hennis, W. Die Spuren Nietzsches im Werk Max Webers. - Jahrbuch der Akademie der Wissenschaften in Göttingen (für das Jahr 1985). Göttingen, Vandenhoeck \& Ruprecht, 1986, 44-69. (Ettekanne Göttingeni TA avalikul istungil 22. novembril 1985.) - Enne politoloog Wilhelm Hennist oli juba aastail 1965-82 mitmes Historische Zeitschrift' is ilmunud artiklis rõhutanud ja analüüsinud "nietzschelikku Weberit" ajaloolane Wolfgang J. Mommsen, kes on lõpuks üheselt ka resümeerinud, et Weberi suhteid (historismiajastu) ajalooteadusega vahendas otsustavalt "nietzschelik vaim" (vt Mommsen, W. J. Max Weber und die moderne Geschichtswissenschaft (Saarbrücker Universitätsreden, 31). Saarbrücken, Universität des Saarlandes, 1989, 5-31, siin 13).

157 Vt Jermatsane, Z. J. Filosofsko-istoricheskaja kontseptsya K. Levita. - TRÜ Toimetised, 599: Filosofskije problemy istoricheskoj nauki. Trudy po filosofii. Otv. red. E. Loone. Tartu, Tartu Riiklik Ülikool, 1982, 124-137. (Nõukogulik-marksistlikku nietzscheaanat kehastas oma "odioossete töödega" Stepan Odujev, vt Odujev, S. F. Tropami Zaratustry. Vlijanie nitssheanstva na nemetskuyu burzhuaznuyu filosofiyu. Moskva, Izdatel'stvo "Mysl”, 1971.)

158 Vt Sineokaya, J. V. Rossijskaya nitssheana. - Nitsshe: pro et contra. Antologiya. Sost. J. V. Sineokaya. Sankt-Peterburg, Izdatel'stvo Russkogo Hristianskogo gumanitarnogo instituta, 2001, 7-34, siin $28 \mathrm{jj}$.

159 Horkheimer, M. Bemerkungen zu Jaspers' "Nietzsche” (1937). - Ders., Gesammelte Schriften, 4: Schriften 1936-1941. Hrsg. von A. Schmidt. Frankfurt a. M., Fischer Taschenbuch Verlag, 1988, 227. 
ise ükskord seda väljendas: 'Kogu mõtlemine on veri, ja nii raske on mõista võõrast verd'." $" 160$

Ajaloo kui eriteaduse silmis on Nietzsche pikka aega olnud "ajaloofilosoof", kes ajalooalase uurimistöö teaduslikke, poliitilisi ja kultuurilisi eesmärke nii teravalt arvustab, et see piirneb historistliku teadusmudeli eitamisega. Võimalik, et Nietzsche palju imetletud "keelekunst", mis teeb tema kriitikakunsti esteetiliselt ligitõmbavaks ja muudab selle retooriliseks mõjutusvahendiks, ei ole teaduse valdkonda kunsti sfäärist eristavatele ajaloolastele ka ainult maitseasi. Nietzsche astus oma kriitikaga üles ajal, kui oli veel käimas ajaloo metoodiliseks teaduseks muutmise protsess, seda paistab ta olevat - muu hulgas - käsitanud "dionüüsilise" elupooluse allutamisena teadusliku progressi kultuurile. Kriitikaga ülesastumine on talle sama mis vastuastumine, tema kriitika ajaloohariduse ja kultuuritraditsiooni pihta on seetõttu ründava iseloomuga, see on "kallaletung" - sealjuures koos kõigi sellisele ettevõtmisele omaste kasude ja kahjudega. Paraku tuleb kahjude rubriiki kanda selle fakti mitte teatavaks võtmine, et Nietzsche on historismi kui ajaloolise relativismi teadvuse üks kõige hiilgavamaid väljendajaid XIX sajandi viimasel veerandil, mil historistlik "tavateadus", sealhulgas algmarksism (Engels siiski rohkem kui "finalistlik" Marx) ${ }^{161}$ panustas positivistliku objektivismi ideaalile. Nietzsche 1880. aastate ideoloogiliselt kuritarvitatud visandid sisaldavad probleemikirjeldusi olematule tõele lähenematust, üksnes "vooluses" ja "saavuses" olevast maailmast, perspektivistlikust maailmapildist. Olulisel määral on selles perspektivismis ära tuntav läänemaailma tänane kultuuriline enesekirjeldus, mida end 1990. aastaist "ajaloolise kultuuriteadusena" ehk üldise kultuuriteaduse ühe erialana määratlev ja seega oma distsiplinaarset identiteeti muutev teaduslik ajalugu ei saa ka metodoloogiliselt eirata. "Et maailma väärtus on meie interpretatsioonis (- et võib-olla kusagil on võimalikud veel teised interpretatsioonid kui pelgalt inimlikud -), et senised interpretatsioonid on perspektiivsed hindamised, mille varal me hoiame ennast elus, st võimutahtes, tahtes võimu kasvule, et iga inimese kõrgendus toob endaga kaasa kitsamate interpretatsioonide ületamise, et iga saavutatud tugevnemine ja võimulaiendus avab ühtlasi uued perspektiivid ning tähendab uskumist uutesse horisontidesse - see läbib minu kirjutisi." ${ }^{162}$ Nietzsche tekstides ei ole seega midagi vähemat kui modernse ühiskonna ja selle kultuurilise struktuuri või, nagu Nietzsche sageli ütleb, "modernse vaimu" teooria elemendid.

160 Adorno, Th. W., Horkheimer, M., Gadamer, H.-G. Über Nietzsche und uns. Zum 50. Todestag des Philosophen (1950). - Horkheimer, M. Gesammelte Schriften, 13: Nachgelassene Schriften 1949-1972. Hrsg. von G. Schmid Noerr. Frankfurt a. M., Fischer Taschenbuch Verlag, 1989, 113.

161 Vt nt Kluchert, G. Geschichtsschreibung und Revolution. Die historischen Schriften von Karl Marx und Friedrich Engels 1846 bis 1852 (problemata, 103). Stuttgart-Bad Cannstatt, frommann-holzboog, 1985.

162 Nietzsche, F. Aus dem Nachlass der Achtzigerjahre. - Ders., Vorspiel einer Philosophie der Zukunft. Aus dem Nachlass. Briefe. Ausgew. und eingel. von K. Löwith. Frankfurt a. M., Fischer Bücherei, 1959, 124 jj. - Nietzsche "võimutahte" mõiste ja geneesi ning selle teooria mõttelooliste seoste kohta vt eelkõige Günter Abeli põhjapaneva uurimuse 1. osa ("Võimutahteprotsessid"): Abel, G. Nietzsche. Die Dynamik der Willen zur Macht und die ewige Wiederkehr. 2., um ein Vorwort erw. Aufl. Berlin/New York, Walter de Gruyter, 1998, 3-184. 
Ent sellest johtuvalt oleks tunnetuslikult sama "viljatu", nagu Otto G. Oexle on arvustanud nende ajaloolaste suhtumist, kes Max Weberit "sotsioloogina" ja Georg Simmelit "filosoofina" tahaksid parema meelega "oma eriala ajaloost eemal hoida" ${ }^{163}$ ka Nietzsche jätmine "ajaloofilosoofina" väljapoole ajalooteadust. See ei ole hoiakuna mõttekas vahest eriti postsotsialistlikus ajalooteaduses, mille marksistlik eellugu tegi 1989. aastani kõik selleks, et välistada Marxi ja Lenini kõrvalt - enamasti vääralt nietzscheanismiga samastatud - Nietzsche pärand ("Nietzsche ei kuulu meie pärandisse, töölisklassi pärandisse, antifašistliku riigi pärandisse..."). ${ }^{164}$ Pöördudes uuesti Nietzsche poole, peab teadus suutma hinnata otsustavalt ümber marksistliku "ajaloolise materialismi" poolt mitmesse ajalugu erialana õppinute põlvkonda süstitud müüdi, et "irratsionaalne" elufilosoofia pole ajalooteadusliku ratsionaalsuse järgijale üldse tähtis. Me peaksime siingi mineviku vulgarismide säilitamise asemel toetuma süstemaatilise uurimise tulemustele, mis lubasid Karl Albertil 1995. aastal nentida, et elufilosoofiale oli "ka huvi ajaloo ja ajalooteaduse vastu" tegelikult "iseloomulik" (charakteristisch) ja Nietzsche oli peale Dilthey - selles suhtes "eelkäija". ${ }^{165}$ Kuid hoolimata sellest, et Nietzsche vaim osaleb poliitikateaduses (1990. aastate ameerika liberalismi kritiseeriv politoloogia on võtnud Nietzsche oma ideoloogia arsenali nn agonistliku poliitika teoreetikuna), tekitab paljalt ta nime esiletoomine ajalooteadlaste ringkonnas - nagu 1970. aastail meil vastuolulisi tundeid. Rolli võib selles mängida Nietzsche nn positivistlikku perioodi jääva positiivse ajalooväärtustuse ("Inimliku, liiginimliku" 5. ptk) ununemine, aga samuti Nietzsche "Ajaloo kasus ja kahjus elule" esineva histooria-sõna valimatu, ehkki mitte alati õige tõlkimine 'ajalooteaduseks', sest Nietzsche hoiak on teoses muutlik. ${ }^{166}$ Osa teosest (HL 5-8) on täpsemas mõttes "eluvaenuliku", minevikku vaatava (ajaloo)teaduse kriitika, seda tendentsi ei kanna aga päriselt kogu

163 Oexle, O. G. Geschichte als Historische Kulturwissenschaft. - Kulturgeschichte Heute. Hrsg. von W. Hardtwig und H.-U. Wehler (Geschichte und Gesellschaft, Sonderheft 16). Göttingen, Vandenhoeck \& Ruprecht, 1996, 31.

164 Nietzsche-vastase ideoloogiavõitluse väljendusrikkamaid dokumente marksistliku teaduse valitsemisaja viimastel tundidel on nt Buhr, M. Es geht um das Phänomen Nietzsche! Marxistische Blätter, 1988, 2, 38-47, siin 40. Varasema vastukriitika kohta vt Kaufhold, B. Zur Nietzsche-Rezeption in der westdeutschen Philosophie der Nachkriegszeit. - Beiträge zur Kritik der gegenwärtigen bürgerlichen Geschichtsphilosophie. Hrsg. von R. Schulz. Berlin, Deutscher Verlag der Wissenschaften, 1958, 279-409. - Marksistliku Nietzsche-tõlgenduse autoriteetidena kehtisid Franz Mehring ja György Lukács.

165 Vt Albert, K. Lebensphilosophie. Von den Anfängen bei Nietzsche bis zu ihrer Kritik bei Lukács. Freiburg/München, Verlag Karl Alber, 1995, 130 jj. - Elufilosoofia Nietzschest erineva mõistmise kohta Dilthey teadusteoorias vt Georg Mischi klassikalist artiklit: Misch, G. Die Idee der Lebensphilosophie in der Theorie der Geisteswissenschaften (1924/1947). Materialien zur Philosophie Wilhelm Diltheys. Hrsg. und eingel. von F. Rodi und H.-U. Lessing. Frankfurt a. M., Suhrkamp Taschenbuch Verlag, 1984, 132-146.

166 Siin tuleb silmas pidada mitmesuguseid seiku, ka seda, et Nietzsche kirjutas traktaadi peatükid erinevas järjekorras, korraldas nende sisu ümber, muutis, töötles ja parandas teksti, olles ajanappuse ja tervisehädade käes. "Peaks olema selgeks saanud, et oma ketserlike mõtete väljatöötamisel ajalooteaduse üle jõudis Nietzsche väga lühikese aja jooksul jämedakoelisest mustvalgest skeemist üsna diferentseeritud positsioonini." (Salaquarda, J. Studien zur Zweiten Unzeitgemässen Betrachtung, 30.) 
ideestik. Kaasaja ajaloolise meele "tormakusele" viidates on peetud silmas ka "tulevate aegade" perspektiivi, midagi alustavat "esiksuse" (Erstlingschaft) tähenduses (HL 9). Tõsi küll, see mõte pigemini vilksatab, kui et seda arendataks, aga see on tähtis: ajaloolisega seondub Nietzschel võimalikuna uudsus.

Kujutlus Nietzschest kui ajaloo eitajast või hävitajast on üks vääramaid, mis temast üldse kujuneda saab, sest ta möönab minevikukohase teabe hädavajalikkust: "iga inimene ja iga rahvas tarvitseb vastavalt oma sihtidele, jõududele ja vajadustele teatud minevikutundmist" $(H L 4)$. Nietzschel võivad praktiliselt kõik ajaloo "viisid" või ajaloolised "hoiakud" - millest 2. "ajakohatu vaatluse" lõppredaktsioonis on peamistena välja kristalliseerunud kolm (monumentaalne, antikvaarne, kriitiline) - elu teenida, aga nad võivad sama hästi ka manduda. Leopardi 1860-ndail saksandatud luuletustega seonduvast inimese ja looma oleluse võrdlusest (HL 1) peale on ilmne, et Nietzsche ei eita ajaloo (Historie) tähtsust elule, vaid küsib, "millise määrani" on ajalugu elule tähtis, soodus ja kasulik (dienlich). Ajalugu peab küll elu teenima, kuid seda elu teenimise ülesannet täidab ajalugu siis, kui subjektiivset ajaloo mõistet ehk histooriat, jutustavat ajalugu, ei muudeta objektiivseks teaduseks (Wissenschaft): see tähendab - nagu ta uskus - millekski subjektituks ja täiesti isiksusetuks ("igavene subjektitus, või nagu öeldakse, objektiivsus") (HL 5; vrd 8). Nietzsche kõneleb oma traktaadi lõpus ka uuest, "ajaloohaiguse" järgsest, kõrgemast "elutundest" juhinduvast ajaloo tarvitamisest, kus minevik on "elu valitsuse all" (HL 10). Siin poleks vaja näha - Weberi joont ajava Oexle kombel - ainult seda, et Nietzsche tahab teaduse allutada elule, vaid ka seda, et ajalugu subjektiveeriv Nietzsche annab 2. "ajakohatu vaatluse" nii mõneski kohas objektiivsuse taotlejale justkui eeskuju, kuidas süüvida ajaloolise identiteedikujunduse neisse kihtidesse, mille kriitiline peegeldamine parandab ühtlasi teadusliku objektiivsuse väljavaateid. Äärmise subjektiivsuse teadvustamine võib olla ajaloolasele kasulik, sest kui suhtumine minevikku on põimunud isiklike eelistuste ja kaalutlustega, on hea anda endale aru, mis paneb eksitama, moonutama, võltsima. Kui aga ollakse sajaprotsendiline nietzscheaan, siis küll, jagades dogmaatiliselt Nietzsche pilkeid ja arvamusi (XIX sajandi) "teaduslikust inimesest", ei saa enam hästi olla ka nüüdisaegses, kultuuriteaduslikus mõttes ajaloolane. Hoolimata sellest on Nietzschel õigustatud "teaduse"-kriitikat (nt $H L$ 7; ka 8) ja ühtlasi nõudeid "ehtsale ajaloolasele" (vt $H L$ 6), mis on omal kohal veel praegugi. Nietzsche teesi, et "ajalugu peab ajaloo probleemi ise lahendama, teadmine peab oma astla iseenda vastu keerama" $(H L$ 8), võib tänapäeval võtta kriitilise identiteedi vormelina. Tema relativismi-elamuse sõnad ("lootusetu skeptiline lõpmatus") (HL 10) olid aga kahtlemata aegaennetavad, ehtsat ajaloolast panevad need kui mitte nietzschelikult "hädasadamat" otsima, siis jätkuvalt küsima, mida on histoori(k)ast elavikule kasu.

\section{Nietzsche kui ajaloo ründaja ja uuendaja}

Mis ajalugu Nietzsche siis ründas? Siin on mõeldav vastata, et ta ründas oma kaasaja ajaloolaste ajalugu, lähiajalugu, aga samuti küsida edasi, mida ta selle ajaloo all mõtles, mida ta sellise ajaloo varjus nägi, ja mis jäi tema enese pilgule varjatuks, 
kui ta ründamise kirjanduslikku plaani võttis. "1873. aasta algul tegi Nietzsche endale pika nimekirja pealkirja all: "Anzugreifen",",167 mainib algse rünnakuplaani kohta ta elu ja loomingu üks esikuurijaid kirjandusteadlane Richard M. Meyer (1860-1914), kes Droyseni ajaloometodoloogia loengute kuulajana oli "nimekirja" suhtes ise küllalt reserveeritud. Nimistu ei sisalda üksnes tuntud isikuid (teadlasi, filosoofe, kirjanikke, kriitikuid), vaid ka paikkondi (Leipzig, Berliin) ja institutsioone (ajakirju, ülikoole, parlamenti), see sisaldab ründeobjekti (saksa kultuuri) "konstruktsiooni", tunnistades meelevallast. Tõepoolest, kui algnimekirja võetud Gervinuse, Ranke ja Mommseni karikeerimisele lisada kas või teose "Sealpool head ja kurja" (1885/86) üldnimelised põhjamised peamiste Ranke-järglaste poliitilise rahvusluse aadressil ("need Sybelid ja Treitschked") ning aasta hiljem "Moraali genealoogias" tehtud kriitilised-iroonilised torked "ajaloolise metoodika" ja "protestantlike ajaloolaste" kohta, ${ }^{168}$ siis... Siis võib mõista, miks seda laadi poleemika autor teadusliku ajalookäsitluse pooldajat, eriti aga klassikalise historismi tundjat, kõiges ei köida. Ma ütlen "kõiges" - seda põhjusel, et Nietzsche kritiseerib õigustatult "moralistlikku" ajalookirjutust ja argumenteerib ka ajalooliste liikumiste alternatiivse kujutamise võimaluste üle ("teisiti jutustada"), mis on teadusele aktuaalne, sest kuulub ajalooteadusliku meetodi heuristilisse valda. Kes aga tunneb üksikasjalikult historiograafialugu, sel ei ole raske märgata, et Nietzsche pakub üle, ta esineb pamfletistina. Tema kirjutistes loodav mulje ühest moodsast (uue aja) professioonist - "haigetest" ajaloolastest, "faktilisse" kiindunud ja "blaseerunud" tegelastest - pole lihtsalt adekvaatne. Samas võib kahelda, kas Nietzsche kriitika oli mõeldud nii isiklikuna või isikuvastasena, nagu esmapilgul tundub. Nagu varajastes traktaatides on Nietzschel ka hiljem pinnuks silmas tendentsid, need kalduvused ja suundumused, mis teatud kultuurivallas moodustavad selle valitseva populaarsfääri, näivad muutvat asjadesse suhtumise epigooniliseks. Kui Nietzsche nimetab mitut oma kaasaja "histoorilist" õpetlast (die historischen), kes olid eakad mehed, nagu filoloog Jakob Bernays ja ajaloolane Ranke, "nooreks raugaks", siis ta ju kahtlemata ei mõtle selle ükskõiksust tähistava väljendiga nende bioloogilist eluiga.

Õieti pole ka Nietzsche ise selline uunikum, et teda peaks nägema ja austama ajaülesena, nagu võib ette tulla ainult mõnes postmodernse lühimäluga apoloogias. Juba Meyer viitas Nietzsche teise, ajalookriitilise "Ajakohatu vaatluse" puhul selle - tõepoolest silmatorkavaile - motiiviloolistele paralleelidele kirjandusteoreetik Ludolf Chr. Wienbargi (1802-1872) 1834. aastal ilmunud "Esteetiliste sõjakäikudega", mis oli pühendatud "noorele Saksamaale". ${ }^{169}$ Ning 1830. aastate

167 Meyer, R. M. Nietzsche. Sein Leben und seine Werke. München, C. H. Beck'sche Verlagsbuchhandlung Oskar Beck, 1913, 255.

168 Vt Nietzsche, F. Werke, Zweiter Teil, 137, 223 ja 271.

169 Vt Meyer, R. M. Nietzsche, 264 jj. - Kirjandusuurijate seas ei ole see tähelepanek erand, Viktor Schweizer nimetas 1897. aastal Wienbargi isegi "Nietzsche eelkäijaks", Rudolf Kayser seostas 1956. aastal Wienbargi otseselt "võitlusega historismi pärast". Pseudodemokraatlikul Ida-Saksamaal, kus valitses negatiivne Nietzsche-retseptsioon ja ajaloousuna kehtis marksistlik objektivism, püüti "Noor-Saksamaa" rühmituse ideoloogi Wienbargi teoste uusväljaande puhul 1960. aastail tema kõrvutust Nietzschega ("selliseid väärotsustusi Wienbargi kohta") diskrediteerida, olgugi et Nietzsche poolt rünnatud suuri ajaloolasi vulgariseerisid oma - "ainuõige" historismi - seisukohalt meelsasti ka idasaksa historiograafid (vt Wienbarg, L. Ästhetische Feldzüge. [Einleitung von W. Dietze.] Berlin u. Weimar, Aufbau-Verlag, 1964, 311 jj). 
algusest peale seeriana kirjutatud retsensioonides tol ajal ilmunud filosoofialugudele käisid Feuerbachil kogu aeg käsikäes tulevase elufilosoofia ja historismikriitika elemendid. Ranke võistleja, konservatiivse ajaloolase Heinrich Leo (1799-1878) noorhegeliaanide-vastase kriitika puhul Feuerbachi 1839. aasta märtsis avaldatud "Õige vaatepunkt", ${ }^{170}$ mille jätkamist takistas Preisi tsensuur, sisaldab "Nietzsche-motiividena" iseloomustatavaid mõtteid. Suure ajakonteksti lõikes on Feuerbachi "eluprintsiibist" lähtuvas ja sõna "historism" kasutavas mõtlemises ennetavaid täheldusi, mida Nietzsche - muudel ajenditel - oma traktaadis on korranud või arendanud, originaalselt teravustanud.

Kas seetõttu võib Nietzsche mainest ajaloolaste silmis lahutamatuks saanud, sageli Schopenhaueri mõju ${ }^{171}$ arvele kantava teadusevaenu asemel talle pigem ette heita võhiklust ja stiilitust? XIX sajandi teise poole kirjanduskultuuris, mida oma jutustusviisiga kujundasid ka ajaloolased, mitte päriselt. Näiteks vene historismi suur klassik Sergei Solovjov (1820-1879) nimetas Ranket, keda ta oli 1840-ndail Berliinis kuulamas käinud, tolle esinemismaneeri tõttu "purjus ahviks". ${ }^{172}$ Solovjovi sõnad ei olnud ilmselt mõeldud solvanguna, vaid teatud loengupidamise vormi võrdlemisena laadateatriga, mis ei jätnud talle saksa professorist head muljet. Varajase Nietzsche peamised kriteeriumid (schopenhauerlus ja wagneriaanlus, arhailine kreeka kultuur), mida ta tundis ja mille alusel ta oma kaasaegse kultuuri ehk "modernsuse" arengute üle otsustas, ei olnud kahtlemata teadusimmanentse iseloomuga. Olgugi et Nietzsche teoste nüüdisaegsed väljaandjad on arvamusel, et nii, nagu oma teisi varajasi töid, ei lasknud Nietzsche ka oma "Ajakohatuid vaatlusi" (1873-76) hiljem ise enam uuesti ära trükkida kaalutlusel, et ei lugenud neid oma "tugevamate" hulka, loeb see asjaolu ajaloo "kasu ja kahju" üle arutleva 2. vaatluse retseptsioonis vähe. Mõni Nietzsche kaasaegne sotsialist, nagu näiteks marksistliku ja parteilise orientatsiooniga ajaloolane Franz Mehring (1846-1919), oli kallaletungist saksa ajaloolastele, kes "vaimulageda" teadushoiakuga "kronistidena" varjavat pealegi "kapitalistlike huvide" järgimist, üsna vaimustatud, leides, et 2. vaatlus on teistest "veel õpetlikum". ${ }^{173}$ Nietzsche teosed said autori tahtest sõltumata sajandivahetuse sotsialistlikus ajakirjanduses peaaegu et parteipoliitiliselt kodanlikku teadust ümberhindava funktsiooni. "Nietzsche "Sealpool head

170 Vt Feuerbach, L. Der wahre Gesichtspunkt, aus welchem der "Leo-Hegelsche Streit" beurteilt werden muss (1839). - Ders., Kleinere Schriften I (1835-1839). 2., durchges. Aufl. (Gesammelte Werke, 8). Hrsg. von W. Schuffenhauer. Berlin, Akademie-Verlag, 1982, 208-218.

171 Vt tema ajaloometafüüsika analüüsi historismiloo ja kultuuriteaduste kontekstis: Scholtz, G. Schopenhauer und die Geschichte (1988/91). - Ders., Zwischen Wissenschaftsanspruch und Orientierungsbedürfnis, 108-129. (Eesti keeles: Scholtz, G. Schopenhauer ja ajalugu. [Tlk M. Kivimäe.] - Looming, 1999, 4, 592-606.) - Vrd ka Nietzsche, F. Das Verhältnis der Schopenhauerischen Philosophie zu einer deutschen Kultur (1872). - Ders., Werke in vier Bänden, IV, 537-540.

172 Solovjov, S. M. Izbrannõje trudõ. Zapiski. Izd. podg. A. A. Levandovski, N. I. Tsimbajev. Moskva, Izdatel'stvo Moskovskogo universiteta, 1983, 272.

173 Mehring, F. Über Nietzsche (1898/99). - Ders., Aufsätze zur Geschichte der Philosophie. Hrsg. von D. Bergner. 2., veränd. und erw. Aufl. Leipzig, Verlag Philipp Reclam jun., 1975, 205. 
ja kurja" on tobe suurustlemine, kui see peab olema üleinimsuse parool, aga sel on kindel mõte protestina vastiku moraliseerimise vastu, nagu see on maad võtnud kodanlikus ajaloo- ja nimelt kirjandusajalookirjutuses." 174 Võiks öelda, et vana kooli sotsiaaldemokraadina olid Mehringi kirjutised Nietzschest ("Kapitalismi filosoofiast", "Nietzsche asjus", "Nietzsche sotsialismi vastu") erudeeritumad ja tasakaalukamad kui tema kommunistidest järelkäijatel. Oma tekstides andis ta sõna ka ajaloolasele ja esseistile Karl Hillebrandile (1829-1884), sellele teadaolevalt esimesele "nimekale kriitikule", kes arvustas Nietzsche traktaati "Ajaloo kasust ja kahjust elule" kohe ilmumisaastal positiivselt ning keda Nietzsche veel 1888. aasta lõpul "Ecce homos" (1908/11) ${ }^{175}$ selle eest vastuülistava tänuga meenutas. Mehring osundas nõustuvalt Hillebrandi poolt (Nietzsche Hegeli-kriitikaga seoses) esile toodud asjaolu, mis on motiivina etendanud osa vaoshoitud suhtumise kujundamisel Nietzschesse ka hiljem, XX sajandil: "Mitte tahta näha, et Hegel viis süsteemi saksa hariduse põhiidee [...], tähendab kas eirata Saksamaa vaimset ajalugu Herderist Feuerbachini või kujutada Saksamaa panust euroopa tsivilisatsiooni väärtusetuna."176 Vaimse traditsiooni kui sellise ignoreerimine mõnes ajalooteaduse harus (nt ideeajaloos) oleks ajaloolasele nonsenss ja võrduks oma teadusharu uurimisobjekti kaotusega.

Kriitikaga, seejuures Nietzsche tüüpi arrogantse kriitikaga, mis on suunatud konkreetsete ajaloolaste või nende koolkondlike moodustiste ja metoodikate vastu, on aga nõnda, et selles tuleb terad eraldada sõkaldest. Põhjusi, miks teaduslikkust hindav ajaloouurija, kellel on kujutlus objektiivse tõlgenduse astmeist, ei saa ajaloomõtlejale Nietzschele igas tema kriitika punktis järele kiita, on mitu (sama käib Hegeli ja E. v. Hartmanni ajaloofilosoofia esituste kohta Nietzsche poolt 2. "ajakohatus vaatluses"). Muidugi pole neid võimalik siinkohal loetleda ega analüüsida, vaid üksnes paari meie teema probleemide jaotuse seisukohalt olulisemat nimetada.

(1) Ajaloolased Nietzsche silmapiiril olid moodsa ajalooteaduse alusepanijad, kas klassikalise historismi eelkäijad (Niebuhr) või selle esindajad (Ranke), või siis nn Preisi koolkonna liikmed, kes "teise ajastu", 1848. aasta järgse perioodi inimestena ja ajaloolaste uue põlvkonna "tegijatena" ka juba ise olid historismi klassikalise vormiga teadusesiseselt opositsioonis. Nii vaidlustasid nad ajaloolase "neutraalsuse" ideaali, taunisid liigset tsunftistumist elulisuse arvel (nt Droysen), tähtsustasid elupraktikast lähtudes uurija subjektiivsust objektiivse tunnetuse saavutamisel. Ranke isetuse-nõuet nimetas Heinrich von Sybel (1817-1895) moraalseks "hingetuseks" vähemalt 20-30 aastat enne Nietzsche täiesti analoogilist historismikriitika passust. Nietzschele omast antikvaarse ajaloosuhte kriitikat

174 Mehring, F. Zu Heines Ehren (1906). - Ders., Aufsätze zur deutschen Literatur von Klopstock bis Weerth (Gesammelte Schriften, 10). Hrsg. von Th. Höhle, H. Koch, J. Schleifstein. Berlin, Dietz Verlag, 1975, 484.

175 Vt Nietzsche, F. Ecce homo. Wie man wird, was man ist (Die Unzeitgemässen). - Ders., Werke, Zweiter Teil, 443 jj. (Eesti keeles: Nietzsche, F. Ecce homo. Kuidas saadakse selleks, mis ollakse. [Tlk ja järels J. Undusk.] Tallinn, Vagabund, 1996, 80 jj.)

Tsit artiklist: Mehring, F. Über Nietzsche, 206. 
võib aga leida juba 15 aastat enne teda ka Wilhelm Giesebrechtil (1814-1889). Viimasel on rahvastevaheliste suhete ajaloo kontseptina eos olemas ka nüüdse "Beziehungsgeschichte" lähedane idee. ${ }^{177}$ See relativeerib aga Nietzsche pretensiooni vastandada saksa ajaloolaste natsionalismile kosmopoliitne eurooplus, olla nende isamaalisusega võrreldes "hea eurooplane". Vähemalt osaliselt ründas Nietzsche 1870.-80. aastail ajaloo käsitlemise printsiipe, mis teadusesiseselt olid selleks ajaks kaotanud aktuaalsuse: juba tema kaasajal ning tema arvustamisest sõltumatult kujunesid teaduses nn kriitilise historismi algmed, mis ühe elemendina kuuluvad praegu ajalooteaduse aluste hulka. Nietzsche historismikriitika teooriapoole nõrk külg on selle üldisustaotluses, laiendamises kogu ajalookirjutusele, mõtlemata histooria faasidele, ka sisemistele erinevustele ja arengutele. "Teooriad historismis" esitati valdavalt implitsiitselt, tähendab, uurimispraktikale tugineva historiograafilise töö vormistuses, mis on historistliku teoorialoome eripära. ${ }^{178}$

(2) Historistliku kultuuri produkt oma teravdatud ajalootajuga oli ka Nietzsche ise, hiljemalt 1910.-20. aastate vahetuseks taipasid seda Troeltsch ("Ta (Nietzsche) mõtles alati genealoogiates ja omas humanismi kultuuri" ${ }^{179}$ ja Meinecke, kelle arvates Nietzsche ammutas "oma jõu" historistliku kultuuri "peentest tunnetustest", just selles viljeldud ajalooharidus andis oskuse hinnata "ka mitteajalooliste instinktide võimu ja tähendust ajaloolises elus" ("Nietzsche paljastatud historismi ohte ei hakata seetõttu ka eitama"). ${ }^{180}$ Kuid Nietzsche kriitiline positsioon umbes 15 kriitika-aasta jooksul on vastakas, eriti ta hilisem ajalookriitika on sõnaosavusele

177 Vt Giesebrecht, W. Die Entwicklung der modernen deutschen Geschichtswissenschaft. HZ, 1859, 1, 1-17, eriti 9 jj. - Rahvusvahelistunud maailmale vastava "komparatiivajaloo" teooria ja taotluste kohta tänapäeval vt: Kocka, J. Comparison and Beyond. - History and Theory, 2003, 42/1, 39-44. Jürgen Kocka on ka juba 10 aastat tagasi sidunud ajaloolaste taastuva huvi "suurte seoste" uurimise vastu ärapöördumisega "ajalookultuuri mängulisest estetiseerimisest", see tähendab, "otsekui post-postmodernse pöördega" (vrd Kocka, J. Perspektiven für die Sozialgeschichte der neunziger Jahre. - Sozialgeschichte, Alltagsgeschichte, MikroHistorie. Eine Diskussion. Hrsg. von W. Schulze. Göttingen, Vandenhoeck \& Ruprecht, 1994, 33-39).

178 Vt selle kohta Rüsen, J. Theorien im Historismus (1980). - Ders., Konfigurationen des Historismus. Studien zur deutschen Wissenschaftskultur. Frankfurt a. M., Suhrkamp Taschenbuch Verlag, 1993, 95-113.

179 Troeltsch, E. Die Krisis des Historismus. - Die Neue Rundschau. XXXIII Jg. der freien Bühne, 6. Heft, 1922, 586. (Artikkel, mis probleemajaloolisest vaatevinklist on kuni 1980. aastateni olnud üks kõige sisukamaid historismikäsitlusi üldse, kujutab endast Troeltschi samal aastal ilmunud suurteose "Historism ja selle probleemid", milles Nietzschet peetakse "vaimuteaduslikuks revolutsionääriks" ja mida Wittram on korduvalt viidanud, lühikest eelkokkuvõtet.) Troeltsch võttis Nietzschet ajaloo üle käiva väitluse partnerina, ka tegi ta selget vahet Nietzsche filosoofia ja nn Nietzsche-kultuse vahel, aga seda on vaja teha tänapäevalgi. Populaarne nietzscheanism, mida omal ajal kritiseerisid mitmed väljapaistvad sotsiaalteadlased, oli Troeltschile massikultuuri nähtus: see olevat "mood masside jaoks", kus "neurasteenilised orjahinged tunnevad joovastust ja naudingut härraskeele žargoonist" (Troeltsch, E. Die Kirche im Leben der Gegenwart. - Weltanschauung. Philosophie und Religion. Schriftleitung: M. Frischeisen-Köhler. Berlin, Verlag Reichl \& Co., 1911, 447).

180 Meinecke, Fr. Persönlichkeit und geschichtliche Welt (1918). - Ders., Zur Theorie und Philosophie der Geschichte, 51. 
ja iseteadvusele vaatamata pealiskaudne: see on "kõiketeadja" literaadi "nägemuslik" kriitika, mida professionaalne ajaloolane tõrguks võrdlemast ta kaasaegsete saksa juhtivajaloolaste teadusliku esseistikaga. Nietzsche arutlused faktuaalse ja fiktsionaalse vahekorrast ajalookirjutuses koos väitega maailmaajaloo viirastuslikkuse kohta ("Kõik ajaloolased jutustavad asjadest, mida ei ole eksisteerinud, välja arvatud kujutluses") ${ }^{181}$ on paraku, võrreldes tolleks ajaks - 1880-ndate alguseks - kujunenud õpetustega ajalookirjutuse tüüpidest (Droysen) ja ajaloolase vaatlejapositsioonist (Burckhardt), absolutiseerivalt verevaesed. Nietzsche täheldus, et ajaloolasedki tegelevad "arvatavate sündmustega" viimaste mõju alusel ja mõjulool on suur võim, sest arvamused arvatavast muutuvad üha uute "arvamuste ja tegude" motiivideks, on küll õige. On aga ilmne, et Nietzsche polnud kursis mõne oma ründeobjekti (nt Sybeli) ajalooteoreetiliste vaadetega, mida oli programmiliselt väljendatud 1850-ndail, rääkimata ta põhiseaduslikku rahvusriiki toetavast poliitikateooriast, mida Nietzsche ei võinudki tunda (Sybeli konservatiivse liberalismi teooria fragmendid avaldati 1959. aastal). ${ }^{182}$

Argument Nietzsche vastu on mingil määral seotud teaduse eetikaga, sellega, et ajaloolane ei nõustu oma kutseala historiograafilise traditsiooni vulgariseerimisega, selle tõlgendamisega "ükskõik kuidas". Eeskätt ajalooteaduse ajaloolaste teatud jahe Nietzsche-distants, nagu see ilmneb näiteks historiograafialoolaste George P. Goochi või Ernst Breisachi standardteostes (Nietzschet mainitakse vaid möödaminnes, seoses Lamprechti või Burckhardtiga) ${ }^{183}$ võiks olla mõneti "loomulik". Ometigi ei anna see nõustumatus teaduslikule ajaloolasele veel küllaldast alust Nietzschet diletandina või tsunftivälise (ajaloo)filosoofilise kirjanikuna eirata, sealjuures tema satiirilisest "õpetlaste" kriitikast $^{184}$ ja ühtlasi kunstilisest maailmakogemusest lähtuvast "teaduse esmakordselt problemaatilisena, küsitavana" võtmisest ${ }^{185}$ mitte välja teha. Vastupidi, sama eetika kohustab meid revideerima kaua püsinud, ajaloolise "normaalteaduse" kuningriigis edasi püsivaid lihtsustatud malle Nietzsche tegelikult mitmemõõtmelisest suhtest historismiga - selle

181 Nietzsche, F. Morgenröte. Gedanken über die moralischen Vorurteile. - Ders., Werke in vier Bänden, III, 503.

Vt Seier, H. Sybels Vorlesung über Politik und die Kontinuität des "staatsbildenden" Liberalismus. - HZ, 1959, 187, 90-112.

Vt Gooch, G. P. History and Historians in the Nineteenth Century. 4th Print. Boston, Beacon Press, 1968, 540; Breisach, E. Historiography: Ancient, Medieval \& Modern. 2nd Ed. Chicago \& London, The University of Chicago Press, 1994, 305.

184 Vt nt tema kuulsale fraasile "Zarathustra pole enam õpetlane" järgnevaid tekstikohti: Nietzsche, F. Also sprach Zarathustra I-IV. (Kritische Studienausgabe, 4. Hrsg. von G. Colli und M. Montinari.) 3. Aufl. München, Deutscher Taschenbuch Verlag/Berlin, New York, Walter de Gruyter, 1993, 160-162. (Eesti keeles: Nietzsche, Fr. Nõnda kõneles Zarathustra. [Tlk J. Palla, redig ja järelkirj J. Semper.] Tartu, Eesti Kirjanduse Selts, 1932, 131-133. - 2. trükk: Tallinn, Olion, 1993.) - Eesti ajaloolastest on nietzschelikule "kasutu ja viljatu teaduse" kriitikale reageerinud Peeter Tarvel oma üldpõhimõtetelt siiani tähelepandavas humanitaarteaduste kaitses (vt Tarvel, P. Humanitaarteaduste hariduslikust väärtusest (1936). - Id, Demokraatia tulevik. Koost T. Karjahärm ja H. Runnel. (Eesti mõttelugu, 43.) Tartu, Ilmamaa, 2002, 119 jj).

185 Nietzsche, F. Die Geburt der Tragödie oder Griechentum und Pessimismus (1870/71). Mit dem Versuch einer Selbstkritik (1886). - Ders., Werke in vier Bänden, I, 584 jj. 
teadusliku, esteetilise ja poliitilise kultuuriga. Tähendab, peale historiograafialoolise vaatepunkti, millest lähtudes saab korrigeerida Nietzsche suhtumist historistlikesse ajaloolastesse, on vaja meil asuda ka probleemajaloolisele seisukohale, millelt võib näha Nietzschet teisiti, teisest rakursist.

Nietzsche, teisiti nähtuna, paistab meile esmajärgulise reageerijana historismi arengukäigus kerkinud objektiivsuse ja relativismi küsimustele ning nende küsimuste kui historistliku kultuuri ühe põhiprobleemi püstitajana. Et meie pluralistlik kultuur on sellesama probleemi pärija, mida teadus nimetab "historismi probleemiks", siis on tänases kultuuris olemas n-ö nietzschelik moment. Nietzsche 1874. aastal ilmunud traktaadi "Ajaloo kasust ja kahjust elule" suur probleemilooline tähtsus on selles, et seal käsitleti esimest korda mõlemat küsimust tunnetuse objektiivsust ja väärtuste relatiivsust - ïksteisega seostatult. ${ }^{186}$ Oma tähenduselt ajaloolisele mõtlemisele võiks seda võrrelda noore Benedetto Croce 1893. aasta traktaadiga narratiivajaloo teooriast "Ajalugu kunsti üldmõistele viiduna". ${ }^{187}$ Ajaloolaste probleem on see aga sellepärast, et ajalugu kui historismiga otseselt seotud distsipliin või eriala peab sellises olukorras end kutsetegevuse alana teaduslikult õigustama. Öeldes Droyseni sõnadega tema 1863. aasta programmartiklist "Ajaloo tõstmine teaduse astmele" - ajalugu peab teadusena määrama "oma teooria ja oma süsteemi". ${ }^{188}$ Küsitavaks muutub ajalooteaduse võimalikkus ning ajaloolane on sunnitud iseendalt küsima: mis on ajaloo kui teaduse tingimused, milline on ajaloolise tunnetuse omapära, milles on ajaloo otstarve?

Kui ka näiteks veel teadusuuendaja Marc Blochi hiljem paljudesse keeltesse, sealhulgas 1983. aastal eesti keelde tõlgitud kuulus "Ajaloo apoloogia", mis on kirja pandud 1941/42. aastal ja esmalt avaldatud 1952. aastal, peab oma ülesandeks valgustada probleemi "milleks on vaja ajalugu", ${ }^{189}$ siis on kogu seda raamatut läbiv probleem - ajaloo võimalused ja õigustatus teadusena - vastukaja historismile.

(3) Probleemajaloo aspektist tähendab Nietzsche-revisjon kaht asja: esiteks, et historismi ajaloos peab Nietzschele kuuluma palju kesksem koht, kui seda talle just nagu historismiloo ääremärkusele möönab traditsiooniline historiograafia, mis on teda tõukeandjana ajaloomõtte kaasajastamiseks alahinnanud; ja teiseks, et elufilosoofiat tuleb vaadelda kui historismiloo enda struktuuri, aga mitte nagu väljastpoolt tulevat provokatsiooni või siis ajalooteadusele segavat kõrvaltegurit.

186 Vt Oexle, O. G. Von Nietzsche zu Max Weber. Wertproblem und Objektivitätsforderung der Wissenschaft im Zeichen des Historismus (1990). - Ders., Geschichtswissenschaft im Zeichen des Historismus. Studien zu Problemgeschichten der Moderne (Kritische Studien zur Geschichtswissenschaft, 116). Göttingen, Vandenhoeck \& Ruprecht, 1996, 73-94 ja 264-268, siin 74 jj.

187 Nietzsche ja Croce traktaatide vahelistele puutepunktidele eelkõige positivismikriitika pinnal on pööranud tähelepanu Ferdinand Fellmann: "Nõnda vaadates nihkub Croce tekst kui ka mitte toonilt, siis ometi mõtteliikumiselt Nietzsche teise "Ajakohatu vaatluse" (1874) lähedusse, mis kujutab üht suurt etappi historismi eneseteadlikuks saamise protsessis." (Fellmann, F. Einleitung: Die Unvergänglichkeit der narrativen Geschichte. - Croce, B. Die Geschichte auf den allgemeinen Begriff der Kunst gebracht (Philosophische Bibliothek, 371). Hamburg, Felix Meiner Verlag, 1984, XVII.)

188 Droysen, J. G. Die Erhebung der Geschichte zum Rang einer Wissenschaft. - HZ, 1863, 9, 4.

189 Bloch, M. Ajaloo apoloogia ehk Ajaloolase amet. [Tlk E. Tarvel.] Tallinn, Eesti Raamat, 1983, 6. 
Nietzsche pole üksnes historismi arvustaja, "antihistorist", vaid teatud mõttes ka historismi pärija, veel enam, arengulooline problematiseerija. Historistliku kultuuri ajalooküllasus tingis seesmise vastureaktsiooni "järeletundmisele". Jörg Salaquarda 1980. aastate detailuuringuist Nietzsche materjalide (visandite, plaanide, allikate) kohta tuleneb, et võtmetraktaadil "Ajaloo kasust ja kahjust elule" on kõrge intertekstuaalsuse aste, huvitav on avastus, et traktaadis "leidub terve rida mõtteid, mida Nietzsche jagab Grillparzeriga, ilma et kõigil juhtudel peaks sellepärast möönma otsest mõjutust". ${ }^{190}$ Ajalooline minevik, mis Nietzsche teadvuses hõlmab kogu euroopaliku kultuuriloo vanast ajast uueni, on ühtlasi tema vaimutoit "negativistliku" kriitikuna. Usutavasti seetõttu toimubki tema "väitlus minevikuga", nagu öeldi juba 1960. aastail Nietzsche ajaloolist teadvust vaid Hegeli omaga võrreldes, "laial rindel" ehk "laiaulatusliku kultuurikriitika" vormis. ${ }^{191}$ Nietzsche ajalookriitika eesmärk, inimese õige suhte leidmine minevikuga, ei olnud aga nii destruktiivne ja irratsionaalne, kui võiks arvata. Tänapäevases mõistes oli see otsinguline, ajalooalast teadmist, meenutuse ja unustuse "jõude" inimeses sotsiaalse ja kultuurilise tegevusega seostav. Kriitika teravik oli - tema mustandite järgi - "ajaloo tähendus ühele kultuurile [Bedeutung der His to rie für eine C u $l$ t $u$ r $]^{\prime \prime}$. 192

Alates 1960-ndate lõpust, 1970-ndate algusest maailma juhtivaks ajaloolaseks tõusnud Georg G. Iggers on 1990. aastail märkinud, et Nietzschel on kultuurikriitiline tähtsus ka nüüdisaegse ajalookirjutuse põhialustele. “... Hiljemalt Nietzschest saadik on muutunud problemaatiliseks ajalookirjutuse aksioomid aksioomid, mis omal ajal moodustasid poliitilistele ajaloolastele, hiljem ka sotsiaalteadusliku orientatsiooniga ajaloolastele nende ajalooteadusliku töö aluse." 193 Kui võtta Iggersi järgi ja Nietzsche mõtte horisondil ühte lausesse kokku kaks olulist aksioomi, siis oleks problemaatiline lause umbes selline: ajalugu on teaduslikult tunnetatav mõtestatud arengu protsess. 1970. aastate alguse Wittramile olnuks see tees lähedane "doktrinäärse iseloomuga" ideoloogiale, vähemalt niivõrd, kuivõrd selles peitub hõlmava maailmatõlgenduse kaudu taotletav "absoluutne kehtivus" ja ühtlasi "vaimne valitsemine". ${ }^{194}$ Tema oli tolleks ajaks marksismikriitilisel seisukohal, et ajaloos ei ole kõik teadustunnetusega hõlmatav ega ka mõttekaks kuulutatav areng. Nietzsche oli selles mõttes filosoofiline antihegeliaan, et ajalugu ei olnud talle - osalt juba 1870. aastaist - mõistuspärane ja progressiivne, vaid midagi "eksperimenteerivat". Vahest eriti selgelt ilmneb see hoiak tema 1880. aastate drastiliseski ülestähenduses ajaloolise progressi kohta.

190 Salaquarda, J. Studien zur Zweiten Unzeitgemässen Betrachtung, 24.

191 Fink, E. Nietzsches Philosophie. 3., verbesserte Aufl. Stuttgart, Berlin, Köln, Mainz, Verlag W. Kohlhammer, 1973, 8.

192 Tsit artiklist: Salaquarda, J. Studien zur Zweiten Unzeitgemässen Betrachtung, 22.

193 Iggers, G. G. Geschichtswissenschaft im 20. Jahrhundert. Ein kritischer Überblick im internationalen Zusammenhang. 2., durchges. Aufl. Göttingen, Vandenhoeck \& Ruprecht, 1996, 10 jj.

194 Ideoloogia mõiste ajaloolis-sotsiaalselt diferentseeritud käsituse kohta "hilisel" Wittramil vt: Wittram, R. Ideologie und Gesinnung. - BB, 1971, 5, 1-2 ja 8-10. 
"Progress. - Et me ei eksiks! Aeg kulgeb edasi - me tahaksime uskuda, et ka kõik see, mis ajas on, läheb samuti edasi, - et areng ongi edasi-arenemine... See on väline mulje, millest satuvad eksitusse kõige mõistlikumad. Aga üheksateistkümnes sajand ei ole kuueteistkümnendaga võrreldes edasiminek, ja 1888. aasta saksa vaim on 1788. aasta saksa vaimuga võrreldes tagasiminek... 'Inimkond' ei edene, ta isegi ei eksisteeri. Tervikaspekt on hiiglasuure eksperimenteerimistöökoja oma, kus mõni asi onnnestub, pudeneb laiali läbi kõigi aegade, ja ütlemata palju nurjub, kus igasugune kord, loogika, seos ning siduvus puudub. Kuidas me tohiksime mitte tunnistada seda, et kristluse esiletulek on décadence'i-[allakäigu-] liikumine?... Et saksa reformatsioon on kristliku barbaarsuse recrudescence [ägenemine]?... Et revolutsioon on hävitanud instinkti ühiskonna suureks organisatsiooniks?... Inimene ei ole looma suhtes mingi progress, kultuuri-hellik on araablase ja korsiklasega võrreldes nurisünnitis, hiinlane on õnnestunud tüüp, nimelt eurooplasest vastupidavam..." ${ }^{195}$

Kui ajalugu ei ole pidev edukäik ja "kristlik inimene" ei ole selles arengu tipp, siis tuleb Nietzschelt ka naturalistlik löök euroopaliku humanismi pihta. Nietzsche tegi sellega õigupoolest küsitavaks ühtse maailmaajaloo mõiste ja sisuliselt väitis, et viimane on "kodanliku maailma" väärtustega seotud minevikukohane projektsioon. Tema progressikriitikas mängis kaasa kristluse ajaloo põhjal kujunenud veendumus, et arengul on mitmeid juuri, suundi ja vorme. Algsete üle võivad hakata domineerima "teised juured" ning kasvatada arengu käigus "väärvorme", mis vaid ekspluateerivad kristluse algataja "püha nime", on vaid formaalselt kristlikud. "Mida Kristus eitas? - Kõike, mida tänapäeval nimetatakse kristlikuks."196 Võiks öelda, et Nietzsche muutis oma "'dekadentsi'-liikumise" ideega probleemseks sellise ajalookirjutuse "aksioomi", mis oli antropoloogiliselt fikseeritud teatud maailmausundile.

Mingi paralleel Nietzsche ajaloolise skeptitsismi juurde on olemas ka ühes Wittrami 1950. aastate märkuses, mis omal ajal äratas tähelepanu ja leidis Iggersilt endalt äramainimist ta "Saksa ajalooteaduses" (1968/71), ${ }^{197}$ tõsi küll, kontekstuaalse nihkega ja seetõttu mitte enam päris adekvaatselt. Lähtudes Burckhardti inimolemuse käsitust vaagivate arutluste üldisest kontekstist, siirdas Wittram ajaloolise relativismi probleemi "fikseeritud inimesepildile", millega ajaloolased töötavad, ja solidariseerus "historismi tunnetusega", mis tegevat nüüdisaegsel ajalooteadusel raskeks apelleerida universaalsele inimloomusele. Seda teravustas lause: "Kas on tegelikult [...] leida eest midagi ühist neandertallase ja Goethe vahel?"198 Nõnda osutas Wittram, et uusimal ajal saab antropoloogilise orientatsiooniga ajaloolastele probleemiks ka humanismi aluste projitseerimine minevikku. "Ainuliselt ja konstantselt inimliku määratlemine valmistab raskusi mitte viima-

195 Nietzsche, F. Aus dem Nachlass der Achtzigerjahre, 153.

196 Samas.

197 Iggers, G. G. Deutsche Geschichtswissenschaft. Eine Kritik der traditionellen Geschichtsauffassung von Herder bis zur Gegenwart. München, Deutscher Taschenbuch Verlag, 1971, 337.

198 Vt Wittram, R. Das Faktum und der Mensch. Bemerkungen zu einigen Grundfragen des Geschichtsinteresses. - HZ, 1958, 185, 68 (R. Wittrami tsitaat teoloog O. Weberilt). 
ses järjekorras sellepärast, et kõik mõisted reedavad oma piiravat päritolemist teatud kindlatest ajaloolistest seostest (mõistus, vaim, kõlbeline vabadus, süüme, vastutus, mina-teadvus) - küll ilma et historiseerumine kui selline tarvitseks kahjustada tõesisaldust. Ajaloolise saatus (das Schicksal des Historischen) kehtib loomulikult ka teoloogilise antropoloogia kohta. Teiselt poolt ei pääse me [...] antropoloogilisest fikseeringust ka siis mitte, kui selgitamisest loobume." ${ }^{199}$ Paraku ei pannud Iggers oma teoses Wittrami "teravat" lauset osundades tähele peamist, mis teatud määral lähendab Wittramit "isegi" Nietzsche käsitusele progressist. Wittrami kriitikaobjekt oli üks teine, tema ajal domineerivaks pürginud "progressiivse" arengu "väärvorm" - nimelt "marksismi-leninismi enam või vähem ühtne ajaloolis-poliitiline antropoloogia". Viimase sotsiaalsete ja vaimsetegi taotluste relativeerimisel pöördus Wittram küll eeskätt "läänemaailma" antropoloogia poole, kuid samas näitas ta ausalt kõigi ühtse inimesepildi, inimesekohase "ühise põhivaate" loomise katsete raskusi ja selle eelduste küsitavusi ajaloos.

Siingi on Nietzsche ja Wittrami vahele paigutatavad Troeltschi kriisiarutlused 1920. aastaist, mil ta nentivalt kirjutas, et "vana uhke progressi- ja inimkonnamõiste" on historismi toimel lagunenud, muutunud "üksnes mööduvate, suhtelise kestvusega mõtte- ja kultuuriseoste" mõisteks. ${ }^{200}$ Eluks ühiskonnas ei vaja inimesed Troeltschi järgi enam "vaimset ühtsust" või "absoluut-monistlikku ühtsuspositsiooni" kui nende sotsiaalset (koos)elu "alles võimaldavat" tingimust, aja saatuseks olevat see, et "me lõpetame kogukondade pluralismis". ${ }^{201}$ Balti ajaloos sai selline pluralism ajalooliseks reaalsuseks tegelikult alles 1990. aastail, mingil relativismi mõjude neutraliseerimise tasandil võistleb sellega tänapäeva poliitikas "euroopa inimese" konstruktsioon, see on ka meie aja uus "individuaalne totaalsus", kui siin kasutada Troeltschi terminit.

Nietzsche-küsimuse vaatlusele regionaalses kontekstis ajendab meid fakt, et balti ajalookirjutuse ajaloolased on läinud Nietzsche suhtest selle ajalookirjutusega vaikides, kui isegi mitte huvitult mööda. Historiograafiliste tööde autorite poolt sageli "suurimaks" balti ajaloolaseks nimetatud Wittrami tekstides on aga periooditi, läbi eri aegade, mitmeid jälgi tema huvist Nietzsche vastu. Jälgede selline olemasolu näitab, et see huvi on olnud püsiv. Küsimus ise on selles, et historismi "põhimõiste" ümber tõstetud probleemidega on Nietzsche - niihästi otseselt kui Troeltschi vahendusel - puudutanud Wittrami "aksioome", mis on ta ajalooteadusliku töö aluseks. Erinevalt Nietzschest Max Weberini viivast teest, mida on nüüdseks ka detailselt uuritud, asub Wittrami historismi loogika Nietzschest Ernst Troeltschini viival teel. See võib olla tema Nietzsche-konteksti unustamise üks lisategur, sest ka Troeltsch on ajaloolaste jaoks olnud üsna kaua, 1980.-90. aastateni, Weberi varjus ja "Troeltschi 'historism"” on saanud kirjanduses omaette tiitelmõisteks alles 2001. aastal.

\footnotetext{
199 Vt Wittram, R. Das Faktum und der Mensch, 70-71.

200 Troeltsch, E. Die Krisis des Historismus, 577.

201 Troeltsch, E. Die Zufälligkeit der Geschichtswahrheiten. - Der Leuchter. Weltanschauung und Lebensgestaltung. Jahrbuch der Schule der Weisheit, 4. Hrsg. vom Grafen H. Keyserling. Darmstadt, Otto Reichl Verlag, 1923, 55 ja 61.
} 


\section{Nietzsche - käendaja reaktsioonis historismile (Wittram ja Keyserling)}

Karl Jaspers esines 1935. aasta kevadel Groningeni ülikoolis Hollandis viie loenguga "Mõistus ja eksistents", mille sissejuhatavas osas ta käsitles põhiliselt kahe XIX sajandi mõtleja - Kierkegaardi ja Nietzsche - suurt "ajaloolist tähendust" oma kaasaja "filosoofilise situatsiooni" mõistmiseks. Muu hulgas ütles ta siis, olles enne kõnelnud taani filosoofist: "See, mida tähendab Nietzsche, on niisama vähe selgeks saanud. Tema mõju ei saavuta Saksamaal ükski teine filosoof. Aga näib, et iga hoiak, iga maailmavaade, iga meelsus võtab ta endale käendajaks [als Gewährsmann]. On võimalik, et keegi meist veel ei tea, mida see mõtlemine tervikuna endas sisaldab ja esile kutsub." Ning samas ta lisas: "Seetõttu on igaühele, kes laseb Kierkegaardil ja Nietzschel endale mõju avaldada, ülesandeks jõuda ausalt selgusele järgmises: kuidas ta nendega tegelikult ümber käib, kuidas ta nendesse suhtub, mis nad talle on, mida ta neist teeb?"202 Raske oleks leida Jaspersi uusasjalikust stiilist täpsemat sõnastust, selgitamaks peale Reinhard Wittrami ajastupärasuste ka tema puhtisiklikku vahekorda "Nietzsche fenomeniga": kuidas Wittram temasse suhtus, mida Nietzsche Wittramile tähendas, mida Wittram temalt sai ja temast tegi?

Vahest on esimese sammuna mõeldav toimimisviis ühe Nietzsche-seoselise mõtlejaisiksuse (Wittrami) ajalooline võrdlemine teise Nietzsche-sfääri esinduskujuga (Keyserlingiga) XX sajandi baltisaksluses. Meie teemaringi ehk historismi temaatika seisukohalt näib see andvat küllalt alust kõnelda ühtlasi millestki sellisest nagu uuema baltisaksa intellektuaalse kultuuri teatud kaksipidisusest või kahest hingest.

Põgusa võrdluse järgi baltisaksa vaimuajaloo materjalil on enam-vähem selge, et kutseajaloolasele Wittramile pidi Nietzsche tähendama midagi hoopis muud kui näiteks baltlasest natuurfilosoofile krahv Hermann Keyserlingile (1880-1946). Nagu Schopenhauer pidas Keyserling "tõeliselt eksaktset" ajalookirjutust võimatuks, tema historiosoofias esinev "üleajaloo" (Übergeschichte) mõiste, tähistamaks inimkonna uut, kõrgemat ja üldisemat seisundit ("oikumeenilist pingeseisundit"), kus tavalisi ajalooprobleeme enam ei kerki, on formaalne laen Nietzschelt. Formaalne seepärast, et on nietzscheliku mõistetarvituse arendus, selle ümbermõtestatud variant. Võib-olla tuleks noort Keyserlingi (tema 1906.-07. aasta Berliini-perioodi teose "Surematus" mitmete asjatundlike Nietzsche-kommentaaride alusel $)^{203}$ lugeda ka professionaalse filosoofilise Nietzsche-retseptsiooni alustajaks nn Balti kultuuriruumis. Wittramist põlvkonna võrra vanemana näib olevat Keyserlingi rohkem köitnud tunnetusliku ehk kognitiivse relativismi üldprobleem

202 Jaspers, K. Vernunft und Existenz. Fünf Vorlesungen. 4. Aufl. München, Zürich, R. Piper, 1987, 30.

203 Vt nt Keyserling, H. G. Unsterblichkeit. Eine Kritik der Beziehungen zwischen Naturgeschehen und menschlicher Vorstellungswelt. München, J. F. Lehmanns Verlag, 1907, 173, 182, 192, $235,286 \mathrm{jj}$. 
kui ajaloorelativismi problemaatika. Keyserling kujutles Nietzschet enda poolt 1920. aasta sügisel Darmstadtis asutatud Tarkuse Kooli vaimse patroonina ning jättis oma kaasaegseile mulje, et ta ise on "Nietzsche järel" Euroopa-idee "parim kehastaja". ${ }^{204}$ On märkimisväärne, et Keyserlingi enda avatus ja sallivus ei tulenenud "liberalismist", vaid oma "parteideülese" missiooni teadvusest: "Tarkuse Kooli ajalooline eesmärk ei ole midagi muud kui oikumeenilisele pingele teed rajada." ${ }^{205}$ Keyserlingi 1919. aastast korraldatud foorumitel osalesid inimesed sõltumata usutunnistusest, rahvuskuuluvusest ja maailmavaatest, teiste seas näiteks ka juhtiv historismiteoreetik Troeltsch. Erinevalt Wittrami natsiperioodist oli Keyserling rahvussotsialismi ja Kolmanda Riigi veendunud vastane, ta käitus nende arvustajana, kui mitte isegi põlgajana. ${ }^{206}$ Isiksuse kõrval ei olnud "rahvas" ja "rahvus" Keyserlingi silmis tähtsad kategooriad, ometi on ta oma teostes esitanud nende kohta üsna palju populaarfilosoofilisi seisukohti (mõni on sobiv "euroideoloogia" lööklauseks, mõni on pseudoaristokratism). Universalist Keyserlingi vaadetes rahvusliku "elumaailma" seosest inimese intellektuaalse arenguga on tähelepanekuid, mis pole veel kaugeltki aegunud, ent Wittrami teaduslik-süsteemsete analüüsidega rahvuslusprobleemide alal need siiski võrdlust ei kannata. Teadust vaimseks jõuks pidanud Wittram ei teinud teadustõe taoliste akadeemiliste väärtuste hindajana elus samasuguseid järeldusi nagu Keyserling, kes pigem tahtis filosoofia teaduslikuks distsipliiniks muutmise peatada, analüütilise "teaduse"tegemise juurest esoteerilise "tarkuse"-taotlemise juurde tagasi pöörata. Niihästi Schopenhaueri ja Nietzsche kui ka Bergsoni, Dilthey ja Simmeli mõjulise elufilosoofia traditsioonis moodustab oma mõtlemise väljakujundamisel küll saksa orientalistide teadustööga (P. Deusseni, H. Oldenbergi, R. Wilhelmi uuringute ja tõlgetega) suhestuv, ent "läänelik-teaduslikule" vaimulaadile oponeeriv Keyserling isikupärase peatüki. Oma vaimseid püüdlusi "tarkusekoolina" institutsionaliseerides kirjutas ta 1920-ndate algul: "Nietzsche ootas, oma ulmas nähtud uue aristokraatia põhjendamise eesmärgil, sotsialistlike konvulsioonide ajastut ja seda me praegu läbi elame... Aga seda ainult möödaminnes. Jäägem põhimõtteliselt tõese juurde, mida Ida tarkus kätkeb, ning valgustagem sellest lähtudes omaenda teed."207 Ka Tarkuse Kooli aastaraamatute järgi otsustades on "Ida tarkus" Keyserlingi spekulatiivne konstrukt ja konstant, "põhimõtteliselt tõese" valdkond ajaloolise kultuuri muutumises. Historism kui relativism taandatakse Keyserlingil tarkuse "kehastumise" kaudu nii vanaaja (nt Buddha ja Konfutsius) kui moodsate aegade isiksustes (nt Goethe ja Tagore), sest tarkus jäävat tarkuseks, ja kehastuste mõistmine olevat vahetu Erfassen (adumine), mitte Wissen (teadmine). Tunnuslik on, et "metafüüsiku" seadis Keyserling vaimses hierarhias "ajaloolasest" ning "ajaloo-

204 Reichls philosophischer Almanach auf das Jahr 1923. Hrsg. von P. Feldkeller. Darmstadt, Otto Reichl Verlag, 1923, 133-139, siin 137.

205 Keyserling, H. G. Wiedergeburt. Darmstadt, Otto Reichl Verlag, 1927, 31.

206 Vt nt Thiess, F. Baltische Begegnungen. - Jahrbuch des baltischen Deutschtums, X, 1963. Hamburg-Hamm, Harry v. Hofmann Verlag, 1962, 10-11.

207 Keyserling, H. v. Loov tunnetus. [Tlk I. Vene.] (Eesti mõttelugu, 22). Tartu, Ilmamaa, 1998, $157 \mathrm{jj}$. 
filosoofi" omakorda "kirjeldavast ajaloolasest" kõrgemale, ${ }^{208}$ samas võib kahelda, kuivõrd selline "tõeintuitsiooni" mõistele toetuv astendus on vaadeldav tõdede hierarhia probleemina.

Kultuuris elades oleme pidevalt selle ajaloolises struktuuris, mitte lihtsalt seda struktuuri asendavas "metafüüsilises tegelikkuses", ja Keyserlingi vahendite kõrval on tarvis ka Wittrami meetodit. Peale aimdusliku "intuitsiooni" ja mõttelise "visiooni" on meil vaja muudki suunajat, ennast selles struktuuris ajalise, sotsiaalse, kultuurilise muutujana, ühtaegu endana ja teisena määratleda aitavat "teadmust". Et ka teada, mis see tarkus on, ja osata eristada, mis moel see kelleski teatud ajastul kuju võtab ning millise publiku jaoks see endast teatud põhjustel tarkust kujutab (muidu aetakse taga "üleajaloolist" illusiooni või olematut "traditsiooni"). Maailmas on olemas kultuuriti erinevaid tarkuseõpetusi, mis kõnelevad teatud eluvormis sisse töötatud praktikatest inimolule vältimatute ülesannetega toimetulekuks. Igasugune tarkuselugu vajab meilt edastamiseks paratamatult ajaloolist mõtestamist, selle kultuuriteaduslikud vahendid on peale andmete kirjelduse ja võrdluse ning etappidest koosneva tõlgenduse ka muutuvad väärtustused. Tegelikult lähtus Keyserling 1910. aastail progressikriitika ja kultuurirelativismi platvormilt, ning väites, et kultuur ei tipne "modernse kultuuriga", tegi ta väärtuste relatiivsusest oma ajaloovaatluse põhimõtte - seda asus ta ise hiljem ületama. "Enam ei kõlba antud aja euroopa kultuuri ideaaliks seada. Sotsiaal-eetiliselt iseloomult seisame Kaug-Ida rahvastest tagapool, spekulatiivses suhtes ületasid meid vanad indialased, plastilises suhtes hellenid. [...] Meie, XX sajandi eurooplased, ei ole kindlasti mitte kõiges loodu kroon. - Siis veel 'loodusrahvaste' probleem: kas on sellist probleemi üleüldse olemas? Võib-olla, aga võib-olla ka mitte."209 Wittramilt leiame alles 1950. aastail seoses kolonialismi probleemiga samalaadset historistlikku kultuuripoliitikat, mis teeb küsitavaks, sest ajaliselt tingituks, kõik Euroopa-kesksed väärtushoiakud, millega õigustatakse oma poliitilist ülimust maailmas.

Lähtudes nn historismikriisi kontekstist Baltikumis, millesse nad baltisaksa õpetlastena mõlemad kuuluvad, tuleb aga silmas pidada järgmist. Kui tahes lahknev Keyserlingi spekulatiivne ajaloofilosoofia Wittrami kriitilisest ajalooteadusest ja tema suhtumisest Nietzschesse ka pole, olid nende mõlema 1920.-30. aastate projektid - universalistlik tarkusepraktika ja partikulaarne rahvaajalugu kogu maailmavaatelise vastandlikkuse juures sarnase funktsiooniga. Niisamuti kui "rahvaühisus" (Wittram) oli "vaimukosmos" (Keyserling), ehkki teistsuguse vormina, reaktsioon historismile. Rääkides "relativismi ületamisest" 1923. aasta Darmstadti ettekandes "Maailmavaade ja elukujundus", märkis Keyserling, et relativism "ei või meile, inimestele, tähendada viimast sõna". ${ }^{210}$ Olulisi viiteid relativismi isiksusliku ületamise püüde mõistmiseks sisaldab juba Keyserlingi

\footnotetext{
208 Vt nt Keyserling, H. G. Das Wesen der Intuition und ihre Rolle in der Philosophie. - Logos. Internationale Zeitschrift für Philosophie der Kultur, 1912, III, 69 ja 73.

209 Keyserling, H. G. Unsterblichkeit, 19.

210 Keyserling, H. G. Wiedergeburt, 74.
} 
15 aastat varasem Tallinna-ettekanne "Indiviid ja ajavaim" (detsembrist 1908) koos selles sporaadiliselt esineva "ajavoolulise" nietzscheanismi kriitikaga. Filosoof apelleeris "kõrgema inimsuse" saavutamisele, see sündivat vaid enesearendusest, "enesekultuurist" (Selbstkultur), mis olevat "produktiivse inimese" tunnus ja ainsana "kestvusele määratud". ${ }^{211}$ Just samuti nagu rahvalik-kogukondlik Wittramil, oli Keyserlingil isiksuslik-vaimne mõeldud vastulausena subjektivismile ja individualismile kui oma aja tendentsidele.

Kuidas on ühitatav oluline fakt, et Wittram põhimõtteliselt aktsepteeris (kuigi mitte ilma reservatsioonideta) "elu teaduslikustamist" moodsas kultuuris, faktiga, et just selle vastu Nietzsche protesteeris, väites elustiihia prioriteetsust teadusetegemise ees ja kaitstes (mitte ainult teaduslikult reeglistatud) ajaloo mõtestamise tüpoloogilist mitmekesisust? Kuidas suhtuvad omavahel Nietzsche 1870. aastate mõtted "ajaloo haigusest" Wittrami mõtisklustega "ajaloo kriisist" - kriisist, mis ei tulevat ajalukku väljast, vaid peituvat tema enese olemuses? Selle kohta võib mõningase ettekujutuse saada ka ühest Wittrami 1960. aastate keskpaiku Nietzschet kaasavast refleksioonist (ajaloo)teaduse mõiste, ajaloolis-kriitilise meetodi ning elu ja teaduse vahekorra üle.

Wittram kutsus Nietzsche tunnistajaks ajaloolase ametile. "Kõige sügavamate muutuste hulka, mida ajaloovaatluses kutsub esile teaduslik ajalugu, kuulub see, et pärandatu ühe osa allahindamine üksnes antikvaarse ajaloona on kaotanud igasuguse mõtte. Kõrvalise ning kaugenenu upsaka diskvalifitseerimise vastu võib kutsuda tunnistajaks juba sellesama Friedrich Nietzsche, kes välkteravalt kirjutas "ajaloolise haiguse" vastu ja kaitses meid "laibaleha" eest. Ühes ülimalt vaimurikkas aforismis aastast 1880 märkis Nietzsche, et kogu ajalugu - nagu ta arvas, suure inimese pärast - "pannakse uuesti kaalule": "ning tuhat mineviku saladust poeb oma peiduurgastest välja - päikese kätte. Pole sugugi ettenähtav, mis kõik veel saab ükskord ajalooks. Minevik on võib-olla ikka veel oluliselt avastamata!" Selle tunnetuse tõde ei tarvitse kitsendada suure inimese "tagasiulatuvale jõule": teadusliku uurimise katkematus protsessis võivad halliks tolmunud igavad asjad sattuda ootamatult mõistvasse valgusse, mis taasäratab nende värvid ja annab neile tagasi tähenduslikkuse väärikuse. Küll ainult ühel eeldusel, mis ühendab loodus- ja vaimuteadust: eeldades äärmist täpsust detaili tajumisel.,"212 Oleks väär näha siin ajaloolist positivismi nietzschelikus rüüs, sest tegemist on apelliga heuristikale, kutsega uuesti- ja teisiti-küsimisele. Mitte juhuslikult ei oletanud Wittram ühes teises sama perioodi ettekandes, et kui moodsa teadlase töös "mõni ajaloopilt õnnestub", on sellel rohkem lähedust "tänase mõtleva maalikunstiga" kui vana historistliku ajaloomaaliga. ${ }^{213}$

211 Vt Keyserling, H. G. Individuum und Zeitgeist. Rede gehalten zu Reval am 15. December 1908. Leipzig/Reval, Rudolf Hartmann/Kluge \& Ströhm, 1909, 20 jj.

212 Wittram, R. Die moderne Geschichtsforschung und die baltische Tradition, 56-57.

213 Vt Wittram, R. Die Zukunft in den Fragestellungen der Geschichtswissenschaft. - Wittram, R., Gadamer, H.-G., Moltmann, J. Geschichte - Element der Zukunft. Vorträge an den Hochschultagen 1965 der Evangelischen Studentengemeinde Tübingen. Tübingen, J. C. B. Mohr (Paul Siebeck), 1965, 32. 
Ühtlasi on tunnuslik "tähenduslikkuse väärikuse" väljend. Wittrami tekstides 1950. aastate lõpust 1970. aastate alguseni on tuvastatav eemaldumine positivistlikust tõsiasjakirjeldusest, ajaloolise "faktograafia" (Faktographie) mõistest, ja selle asemel järjekindel hermeneutilise tõlgendamise kategooria "tähenduslikkus" (Bedeutsamkeit) kasutamine. Tähenduslik ei seondu siin faktilise õigsusega, vaid kultuurilist tähendust omavaga, sellega, mida nähtus ajaloos kellegi jaoks tähendab, mille poolest see talle on tähtis ning miks ta seda tähendust vajab. Historismi teoorias on "tähenduslikkus" määratletud ka kui "kategooria mitteilmse, süva- ja tagamõtte jaoks". ${ }^{214}$ Kutsudes Nietzsche tunnistajaks ajalookäsitluse muutunud eesmärkide asjus, tegi Wittram seda hermeneutilise mõttesuunitluse raames.

Pidades silmas teatud ajalõikude erinevat kaalu isiksusele, teaduse muutuvaid arengusuundi ühiskonnas, poliitilist kliimat, tuleb veel küsida: kas saab fikseerida eri etappe Wittrami pöördumises Nietzsche poole? Seda enam, et vaadates 1972. aasta lõpul (mõni kuu enne surma) veel kord tagasi 1945. aasta Zusammenbruch'i järgsele ajale, kui Nietzsche aktsiate kurss saksa ajalookultuuris oli madalaim, tõstis Wittram oma tolle perioodi tugilektüürist esile "kristlikku mõtlejat" Lutherit ja Karl Marxi, rõhutades - antagonismide alahindamise eest hoiatavat "dialektikut Marxi". ${ }^{215}$ Miks kandus Wittramil "hoiatuse" metafoor, mille kandjaks tal 1937/38. aastate ümber oli Nietzsche ("Nietzsche hoiatushüüd, mida ei võetud kuulda"), ${ }^{216}$ edasi Marxile, on ehk ajastu poliitilises seoses arusaadav, aga kas Marx tähendab siinkohal ka (nagu ortodoksses marksismis) otsekohe Anti-Nietzschet? Usutavasti mitte, näiteks eelneva võrdluse osapool Nietzsche-konteksti raames, Keyserling, on 1936. aastal avaldanud samuti tunnustust Marxile, isegi sõltumata tema majandusõpetuse või ajalooteooria paikapidavusest. ${ }^{217}$ Oletada võib, et Marx ei asendanud Wittrami jaoks Nietzschet. Vahel pöördus ta Marxi poole ka marksismiga peetava teadusliku poleemika huvides, nii näiteks väitluses (eesti ja läti) nõukogude ajaloolastega kaitses ta Marxile toetudes - praegu sotsiaalteadustes tunnustatud teesi, et progress ja regress võivad ajaloos olla "dialektiliselt ristatud". ${ }^{218}$ On tõendeid, et nii nagu sotsiaalsete antagonismide alal Marx, jäi Wittramile elu ja ajaloo suhetes hoiatajaks Nietzsche. Selle tunnistuseks on 1968. aasta suvesemestril peetud lõpuloeng üliõpilastele, kus Wittram tegi enda poolt samas üle 10 aasta varem öeldule (auto)kommentaari. "Võib aga ka olla [...], et me peame end ahnete varjude eest kaitsma, et lahkunud istuvad meie juurde lauda ja söövad meie eest ära leiva, et nad panevad meid sadulasse ja lasevad kaasa ratsutada

214 Vt Scholtz, G. Bedeutsamkeit. Zur Entstehungsgeschichte eines Grundbegriffs der hermeneutischen Philosophie (1989/91). - Ders., Zwischen Wissenschaftsanspruch und Orientierungsbedürfnis, 254-268, siin 268.

215 Vt Wittram, R. Die Erheblichkeit der Forschung. Zum Problem der gesellschaftlichen Relevanz der Historie. - Saeculum, 1972, XXIII/3, 225 jj.

216 Vt Wittram, R. Historismus und Geschichtsbewusstsein, 555.

217 Vt nt Keyserling, H. G. Das Buch vom persönlichen Leben. Stuttgart/Berlin, Deutsche VerlagsAnstalt, 1936, 96.

218 Vt eriti Wittram, R. Methodologische und geschichtstheoretische Überlegungen zu Problemen der baltischen Geschichtsforschung. - ZfO, 1971, 4, 606 jj. 
sinna, kuhu meie ei taha. Ajalugu võib meid halvata ja nõrgestada, ära nõiduda ja ebategelikustada. Nõnda jääb meile kõrva Nietzsche kuulus hoiatus: ärge suhelge liiga palju surnutega, muidu hakkab läpastushais teile endale külge!"219 Kas meil on nüüd küllalt alust väita, et elu ja ajaloo tasakaalu ehtnietzschelik probleem läbib Wittrami ajaloolist mõtlemist ühe selle püsiteemana - ainult tema didaktiliseks võtteks ei saa seda mõtteorientiirina esinevat korduvmotiivi ju pidada?

Meie küsimused on omal kohal seetõttu, et vähemalt alates Riia ettekandest "Ajalooteadvus ja ajalookäsitlus baltisaksluses" (7. detsembril 1934) ning lõpetades Bad Godesbergi ettekandega "Moodne ajaloouurimine ja balti traditsioon" (25. juunil 1967) on tekstiliselt tuvastatav, et Nietzsche - kui ajaloo ja kogu historistliku kultuuri toimet elule vaagiv autor - mitte ainult ei läinud Wittramile ajaloomõtlejana korda, vaid ka teritas tema ajalooalast probleemiteadvust. Nietzsche poole pöördus Wittram peale selle veel oma esinduslikes Göttingeni loengukursustes "Ajaloohuvi" (1955/56 ja 1957/58) ning "Ajaloo pretensioon ja küsitavus" (1968/69). Nendele küsimustele tuleb siiski alles täpsemat vastust otsida, ja mõnes mõttes tuleb Wittrami-uurimine sellistele küsimustele vastuste otsimiseks isegi alles vabastada, teadvustades, et nn historismikriisi teema kaudu osaleb Wittram ühena vähestest tõsiajaloolastest, nagu Keyserling omakorda elufilosoofilise kultuurifilosoofina, Nietzsche retseptsiooniloos.

\section{KOKKUVÕTTEKS Interpretatsioon ja autentsusprobleem}

Kui jätta siin kõrvale teadusloolises uurimises viimastel aastatel enim kilbile tõstetud mõlemad "suured klassikud", 1920. aastate algul surnud Ernst Troeltschi ja Max Weberi, kelle mõttemaailma valdasid Nietzsche seatud küsimused ajaloolisele kultuurile ja teadusele, siis võib öelda järgmist. XX sajandi juhtivatest saksa ajaloolastest mängis Nietzsche fenomen peale Wittrami sama olulist rolli vahest veel üksnes kahel: Nietzsche käsitusega historismist väidelnud Friedrich Meinecke (1862-1954) ja Nietzsche poliitilisi vaateid analüüsinud Theodor Schiederi (1908-1984) juures. ${ }^{220}$ Ühelt poolt Wittrami, teiselt poolt Meinecke ja Schiederi vahel on aga vähemalt kaks erinevust. Esimene silmatorkav erinevus nende vahel on ealine: Meinecke ja Schieder pöördusid Nietzsche poole peaasjalikult küpses

219 Wittram, R. Anspruch und Fragwürdigkeit der Geschichte, 95.

220

Vt Meinecke, Fr. Persönlichkeit und geschichtliche Welt, 30-60, eriti 50 jj (aastail 1922-48 ilmus artiklist veel 4 taastrükki); Schieder, Th. Nietzsche und Bismarck. - HZ, 1963, 196, 320-342; vrd ka Schiederi Nietzsche-passust 1. "ajakohatust vaatlusest" (1873) ja selle kommentaari olulises artiklis: Schieder, Th. Grundfragen der neueren deutschen Geschichte. Zum Problem der historischen Urteilsbildung. - HZ, 1961, 192, 1-16, siin 13. (Metoodilise ajaloolase kohta üllatavalt omistab Schieder Nietzschele - "pragmaatilist, teaduslik-tehnilist kultuuri" soosima hakanud 1871. aasta "uue rahvusriigi" ja 1750.-1850. aastail "humanistlikku ja esteetilist kultuuri" arendanud "saksa vaimu" vastandlikkuse küsimuses - erilise võime "nägijalikult [seherisch] väljendada ajaloolist tõde".) 
eas vilunud ajaloouurijatena, nende puhul võib rääkida ka järelrefleksioonist, Wittram aga juba noorena oma teadlasetee algul, n-ö oma "tormi ja tungi" perioodil. Teiseks tuleb märkida sisulist erinevust: kui Meinecke oli historismi (ideeajalooline) uuendustaotleja ning kaemuslik estetist, Schieder aga väga hea (metodoloogiline) hilishistorist, kelle analüüsid on korrektsed ja nauditavad, siis Wittram tundub nendega võrreldes ajuti rohkem piirilkõndijana ka distsiplinaarses mõttes. Nii on ajaloolise meetodi rakendamiseltki huvitav võrrelda kaht XX sajandi keskpaiga historiograafilise teoseanalüüsi näidist: Schiederi 1964. aasta eritlust Ranke "Uuema ajaloo epohhidest" ning Wittrami 1954. aasta käsitlust Schirreni "Liivimaa vastusest". Schiederi analüüs on teekond, ta avab üksteise järel ajaloolise galerii uksed, Wittram aga lähtub konkreetsest situatsioonist, ja selle läbi ta otsekui punkteerib aega. Pole võimalik tõestada, kuid tohib oletada, et "situatsiooni" analüüsimise asetamine "protsessi" käsitlemisest tähtsuselt alati ettepoole Wittrami tekstides võib olla nõrgalt seotud ka tema Nietzsche-taustaga, nimelt 2. "ajakohatu vaatluse" kriitikaga XIX sajandi ajaloofilosoofia (maailma)protsessi mõiste pihta.

"Piirküsimused", Grenzfragen, nagu kõlab ühe Wittrami raamatu - "Tulevik ajaloos" - pealkirja sõna, on wittramlikud küsimused elu ja teaduse, teadmise ja usu piirimail. Need on (jällegi tema sõnaga) "ajavangistuses" olija küsimused. Võib-olla siin tekib teaduspraktika väliselt puhtsubjektiivne tunne, et Wittrami kujus leidub veel mingi "kvaasiteaduslik", mõttelooline seos nietzschelike ideede ja algetega.

Umbes nii nagu Nietzschel peidab ka Wittramil see, mis on kultuuriline, enda loomulikes alustes midagi vastuolulist ja ajatumedat, vahetevahel pea kohatuseni ajas ulatuvaid kindlusetuse seisundeid, mis panevad teda edasi-tagasi pärima. Lühidalt - see on talle pidevalt midagi ühele ajaolukorrale kitsendavat ja ühtaegu sellestsamast vallandavat, inimesele traagilist saamist pakkuvat. Nagu teada, on Nietzschel seoses sellega tähtsal kohal nautilised metafoorid, laevasõit ja meresadam, hilisel Wittramil tuleb analoogilises seoses kõne alla traditsiooni mõiste. Ometi pole ka traditsioonis midagi püsivat ja kindlat, see on Wittramil "sisukuse, kestvuse ja rahu" järele tuntava "väga inimliku iha" väljendus. Iialgi ei võivat selle juures unustada põhilist, faktilist - seda, "et meie kui inimesed jääme saadetuks (ausgesetzt bleiben) sellesse äärmiselt ohtlikusse olemasolemisse, mida nimetatakse ajalooks". ${ }^{221}$ Ajalool ei ole sellisena eesmärki, kuid on palju mõtendeid, selleks on ka traditsioonid, mida inimesed oma kultuuris loovad, aga needki, olles iseloomustatavad ajutistena, alluvad saamisele ja kadumisele. "Ka traditsioonid on üks 'provisoorium'. Hoolsam tegelemine nendega näitab nende lõplikkust, muutuvust ja kaduvust." ${ }^{222}$ Kuigi siin pole tegu Nietzsche herakleitosliku "intuitiivse kujutlusega" maailmakäigust, vaid pigem kultuurilise ja poliitilise ajalookogemuse töötlusega meetodipärase teadusliku kaalutluse abil, valdab Wittrami mõtet asjade "mitte-enam-sama" olemise kujutlus. Et Wittrami radikaalselt historistlikus mõtlemises on erinevaid aspekte, on selge, mõnda neist, ajalooteaduse ja

221 Wittram, R. Das Interesse an der Geschichte, 110.

222 Samas. 
kultuurifilosoofia piiritsoonis asuvat siirdeaspekti, võib aga rekonstruktiivselt hinnata ka mõttelooliselt nietzschelikuks.

Professionaalsed ajaloolased on suhtunud Friedrich Nietzschesse "üldjuhul" kuni XX sajandi viimase kümnendini pigem tagasitõrjuvalt kui omaksvõtvalt, ${ }^{223}$ ta ajaloovaateid on käsitlenud põhiliselt filosoofialoolased. Spetsiaaluurimust Nietzsche ideede retseptsioonist ühe või teise maa "tsunftiajaloolaste" hulgas ei ole minu teada veel kirjutatud, historiograafialoolaste tähelepanu on aga Nietzsche fenomen köitnud enamasti suhetes ja kõrvutuses Jacob Burckhardtiga. Teataval määral näib see olevat algul olnud nii ka Wittrami enda puhul, igatahes tema varases ajaloolis-poliitilises publitsistikas esineb vaheldumisi viiteid mõlemale. Milline oli selles Wittrami huvide tollases jaotuses Nietzsche ja Burckhardti vahel tema Eestist (Käinast Hiiumaal) pärit akadeemilise õpetaja Johannes Halleri (18651947) võimalik roll, on praegu raskesti määratletav. Haller hindas Burckhardtit just ajaloomõtlejana äärmiselt kõrgelt, ilmselt pole meie kultuuriruumiga seotud ajaloolastest mitte keegi kirjutanud Burckhardtist nii sügavalt ja lugupidavalt nagu Haller oma "Mälestustes". ${ }^{224}$ Nähtavasti ainult tema juba surmahaige seisund ei võimaldanud Burckhardtil teda külastada soovinud noort Hallerit 1897. aastal Baselis enam isiklikult vastu võtta, mistõttu jäi ära nende vahetu kohtumine. Juhumärkuse Wittrami õpetaja Halleri kokkupuute kohta "Burckhardti vaimuga" leiab esmalt Nietzsche ja seejärel Burckhardti austajana ennast määratlenud filosoofilise

223 Vt Hardtwig, W. Geschichtsstudium, Geschichtswissenschaft und Geschichtstheorie in Deutschland von der Aufklärung bis zur Gegenwart. - Ders., Geschichtskultur und Wissenschaft. München, Deutscher Taschenbuch Verlag, 1990, 13-57; siin on (54) seoses Nietzsche 2. "ajakohatu vaatluse" eristusega, mida Hardtwig tõlgendab psühholoogiliselt, eristusena inimese "kolme ajaloolise põhivajaduse" ehk tema "minevikuhuvi psühholoogia" (monumentaalse, antikvaarse ja kriitilise "huvi") vahel, muu hulgas öeldud: "See tüpoloogia on ajaloolaste teoreetilishistoriograafialoolises refleksioonis niisama hästi kui täielikult tähelepanuta jäetud, eelkõige küll sellepärast, et see paigutub antropoloogiliste antuste teaduseelsesse valdkonda, ajaloo teaduslikkuse konstitueerimiseks midagi ei anna ning tuleb Nietzsche põhimõttelisest vaenulikkusest positivistliku teaduskäsituse vastu otsekui alles välja prepareerida; sellele lisandub kindlasti ka Nietzsche problemaatiline mõjulugu Kolmandas Riigis." - Meieaegse Nietzsche-uurimise ja nüüdsete historismiuuringute tulemuste ühendamisel tuleb pidada siiani ajaloolaste hulgas ikka veel ringlevat arvamust, nagu tähistaks nietzschelik tüpoloogia mingeid "ajalookirjutuse" või ka "ajalookäsituse" viise, tõepoolest ekslikuks ja sellisena aegunuks. Nietzschele, nagu saab osutada tema traktaadi hoolikama analüüsiga, olid monumentaalne, antikvaarne ja kriitiline ajalugu ennekõike "elu" ja "ajaloo" vahelise seose või suhte kolm viisi, seega kolm nendevahelist "sidestusviisi" (vrd ka Albert, K. Lebensphilosophie, 55 jj). "Monumentaalse ajaloo" kriitika oma nurgakiviks tegev ja muidu värsket lähenemisviisi demonstreeriv kodumaine ajalookäsitlus (vt nt Tamm, M. Monumentaalne ajalugu. Mida me mäletame Eesti ajaloost? - Vikerkaar, 2003, 10/11, 60-68) pole end - Nietzsche tüpoloogiale apelleerides - sellest ajaloolaste traditsioonilisest arvamusringist päriselt välja murdnud. Probleem on veel selles, et Nietzsche poole pöördudes ei peaks nüüdisajaloolane mitte ainult kasutama tema tüpoloogiat etteantud kriitikamallina, vaid söandama esitada ka Nietzsche aadressil kriitilise küsimuse: kas elu ja ajaloo suhe on kirjeldatav ainult nende kolme viisiga?

Vt Haller, J. Lebenserinnerungen. Gesehenes - Gehörtes - Gedachtes. Stuttgart, W. Kohlhammer Verlag, 1960, 210-213. 
kirjaniku Hermann Hesse 1930. aastate mälestustest. ${ }^{225}$ Haller jõudis aga õppida tundma Nietzsche sõpra, Peterburist pärit ja Baselis kirikulugu õpetanud Franz C. Overbeckki (1837-1905), XIX sajandi teise poole liberaal-teoloogilise historismi otsustavat kriitikut. Selle tutvuse kirjelduse põhjal on meil alust väita, et Halleri suhe Nietzschesse oli pigem negatiivne, igal juhul mitte eriti sümpatiseeriv. Pidades silmas seda, et Overbeck jäi omas ajas autsaideriks, kuid et tema (Nietzsche poolt toetatud) mõtted kristluse suhtest kultuuriga avaldasid mõju I maailmasõja järgses teoloogilises situatsioonis, on Haller seoses tema pärastise tuntuks saamisega öelnud lühidalt välja ka oma arvamuse Nietzschest. "Väljaandja, tema (Overbecki) õpilane Carl Albrecht Bernoulli, tutvustas teda maailmale ning käsitles põhjalikult eriti tema vahekorda Nietzschega. Tolle kohta ei tea ma midagi öelda, sest mu vastumeelsus selle haiglase mõtlejakuju suhtes oli ammust ajast nii sügav, et ma vältisin alati temast kõnelemist Overbeckiga. Seda meelsamini vestlesin temaga ta erialast, kirikuloost, ja seejuures, nagu ma usun, õppisin mõndagi, mida ei olnud leida üheski raamatus." ${ }^{, 26}$ Baltluse kontekstis on Halleri suhtumine Nietzschesse mõneti sarnane Schroederi omale, see teeb ta retseptsiooniloolise mõjukanalina, mille kaudu Wittram sattunuks Nietzsche ajalookriitika teele, vähetõenäoliseks. Samas on aga tähelepanuväärne, et väike Basel ("Baseli intermezzo") oli Hallerile tegelikult suure vaimuelu kujund ja seega märksa enamat kui geograafiline paik.

225 Vt Hesse, H. Beim Einzug in ein neues Haus (1931); Basler Erinnerungen (1937). - Ders., Bilderbuch der Erinnerungen. Hrsg. von F. Hofmann. Berlin und Weimar, Aufbau-Verlag, 1986, 158-179; 283-288. Hesse saabus Tübingenist Baselisse 1899. aastal; Haller töötas Roomast tulnuna Baselis 1897-1900 eradotsendina, olles 1897. aastal samas habiliteerunud kuulsa historiograafialoolase Eduard Fueteri juures (vt Faulenbach, B. Haller, Johannes. - Historikerlexikon. Von der Antike bis zum 20. Jahrhundert. Hrsg. von R. vom Bruch und R. A. Müller. München, Verlag C. H. Beck, 1991, 123-124). Hesse meenutab 1931. aastal: "Väike ring inimesi Baselis, kes mind tookord vastu võttis ja harida aitas, oli täiesti läbi imbunud Jacob Burckhardti mõjust, kes alles äsja oli surnud ja kes pidi siis minu elu teisel poolel võtma järk-järgult sisse selle koha, mis varem oli kuulunud Nietzschele" (162) ja lisab 1937. aastal toonaste "noorte õpetlaste" kohta, keda ta seal "tundma õppis", juurde: "Kõige sagedamini nägin ma Joëli, Wölfflinit, Mezi ja Bertholet'd, ka Joh. Hallerit" (286). - Nagu teada, oli kreeka filosoofiale spetsialiseerunud ja ka Nietzschet uurinud Karl Joël esimene, kes 1918. aastal avaldas raamatu Burckhardtist "kui ajaloofilosoofist". Olgu arvesse võetud, et Halleri II maailmasõja ajal kirjutatud mälestused ilmusid Wittrami toimetatuna ja lühendatuna trükist 1960. aastal (vt ka Rimscha, H. v. Johannes Hallers Lebenserinnerungen. - BH, 1961, 3, 179-184), seega Hesse meenutustest umbes veerand sajandit hiljem. "Väike Eesti", tema "baltlasest isa" noorusmaa, eksisteeris Hessele, kes seda maad kunagi ei näinud, ta enda tunnistusel vaid isa jutustustes (vt Hesse, H. Baltisches Erbe. Fünfundsechzig Beiträge in Berichten und Selbstzeugnissen. Hrsg. von E. Thomson. Frankfurt a. M., Wolfgang Weidlich, 1964, 138-139). Eestist venestusajal lahkunud, aga "kodumaatunde" säilitanud Haller ei kodunenud Saksamaal kunagi: ehkki ta oli tulihingeline saksa rahvuslane, ei olnud ta hingelt natsionaalsotsialist. Halleri "trauma" avaldus selles, et ta ei sallinud eluaeg venelasi ja vene keelt - mida ei saa öelda Wittrami kohta, kes on nentinud Halleri "noorusaastaist pärit russofoobiat" (Wittram, R. Nachwort. - Haller, J. Lebenserinnerungen, 277). Eesti keelt rääkis Haller seevastu - mälestuste järgi otsustades "sageli ja meelsasti" (ka baltisakslastega) ning suhtus eestlastesse poolehoiuga. Ainus tekstikoht, kus hiline Wittram kõneleb expressis verbis ajaloo irratsionaalsusest inimese suhtes, näibki olevat Halleri memuaaride järelsõna.

Haller, J. Lebenserinnerungen, 208. 
Teatud kohametafoori tähenduses, arvestades Nietzsche õppetegevust Baseli ülikoolis ja pedagoogiumis (1869-1876/79) ${ }^{227}$ sel ajal, kui ta kirjutas ning avaldas "Ajakohatud vaatlused", võib neid seiku meenutada. Kas ei võeta aga meenutamist kujundi abil ka ajaloolaste töödes sageli vaesestatult, üksnes "meeldetoomise" aktina?

Märkamata jäetakse, et pealtnäha lihtsast metafoorist koorub välja tihendatud kogus kultuurist arusaamiseks tähendust omavat teavet, meie ees on mitmeid isikuid, mõtteid, reise, paiku, seoseid, toimeid kätkev vägagi keerukas faktiline moodustis - paljusisaldav kultuurifakt. ${ }^{228}$ Kultuurifakt on sellisena ka teos Nietzsche traktaat "Ajaloo kasust ja kahjust elule". Niihästi mõnel loomisetapil jagatud autorsusega (nt teose osi dikteeris autor ühele sõbrale Carl v. Gersdorffile, korrektuuri aitas teha teine sõber Erwin Rohde) kui ka psühholoogilise tagasimõjuga autoriisiksusele (Nietzsche enesehinnangus mängis Salaquarda infol rolli esmapubliku - Wagnerite - pisut silmakirjalik arvamus). Teos on seega äärmiselt "subjektisõlteline" kultuurifakt, ka selle poolest, et ta näiteks Wittrami poolt omaksvõetuna saab just selleks teoseks, mis ta on balti ajalookirjanduses "meie jaoks". XXI sajandi algul oleks ehk vaja tuua kultuurifakti teooria Balti historiograafia metodoloogiasse, et hoiduda sotsiologismist, objekti teatud "valmiskonstruimisest" sotsiaalsel või rahvuslikul tasandil, arvestamata neid loometeoseid, produktiivse tegevuse "loomendeid", mis omandavad tähenduse subjektiivses osavõtus nendest, ajaloolase suhtlemises nendega, ja kaitsta end sellega "ajavaimu"-skeemide üleannuse eest.

Episood teaduse sotsioloogias, et hüvastijätukõne Nietzschele pidas kutseline ajaloolane, 1890. aastate "meetodivaidluses" Lamprechti sotsiaal- ja kultuuriajaloo innovatiivset projekti toetanud uuendusmeelne Kurt Breysig (1866-1940), ${ }^{229}$ kes ise jäi ofitsiaalsete ajaloolaste tsunftile kauaks ajaks autsaideriks, ${ }^{230}$ on faktina nii-

227 Vt selle kohta Nietzsche-biograafi Curt Paul Janzi spetsiaaluurimust, mis esitab ülevaate ka Nietzsche poolt käsitletud autoritest, teostest ja teemadest semestrite kaupa: Janz, C. P. Friedrich Nietzsches akademische Lehrtätigkeit in Basel 1869-1879. - Nietzsche-Studien, 1974, 3, 192-203. Nüüdisaja kulturoloogias arendatava "kultuurifakti" (fait culturel) teooria kohta, mida eristatakse "sotsiaalfakti" (fait social) kontseptsioonist, vt eelkõige: Konersmann, R. Kulturphilosophie zur Einführung. Hamburg, Junius Verlag, 2003, 106-123 ja 163-166.

229 Vt Breysig, K. Friedrich Nietzsche (1900). - Ders., Aus meinen Tagen und Träumen. Memoiren, Aufzeichnungen, Briefe, Gespräche. Aus dem Nachlass hrsg. von G. Breysig und M. Landmann. Berlin, Walter de Gruyter, 1962, 57-65.

230 Vt Oestreich, G. Die Fachhistorie und die Anfänge der sozialgeschichtlichen Forschung in Deutschland. - HZ, 1969, 208, 320-363. - Gerhard Oestreichi selles teaduslooliselt põhjapanevas artiklis väljendatud seisukohta, et algul võrdleva sotsiaalajaloo ja sotsioloogia ehk "ühiskonna-, riigi- ja kõlblusõpetuse" vahel kõikunud ja siis oma "Uusaja kultuuriloos" (1900/01) väljundi leidnud Breysigi ideed tekkisid "Nietzsche ja Spenceri mõjul", kinnitab ka Breysigi eelviidatud tekst, kus ta peab Nietzsche tähendust "ühiskonnateadusele" kui noorele "uurimisharule" võrreldavaks "ainult Comte'i, selle rajaja" panusega (vrd Breysig, K. Friedrich Nietzsche, 59). Nüüdisajal on hästi dokumenteeritud ja üldiselt teada fakt, et Nietzschest olid tugevasti mõjutatud kõik kolm 1850.-60. aastate paiku sündinud moodsa sotsiaal- ja kultuuriteaduse klassikut: Ferdinand Tönnies, Georg Simmel, Max Weber. Kuid sama kehtib ka industriaalühiskonna teooria ühe looja, sotsiaalajalookirjutusele impulsse andnud "Nietzsche-järgse hegeliaani" Hans Freyeri kohta, kes noorena õppis Lamprechti juures (vt Muller, J. Z. The Other God That Failed. Hans Freyer and the Deradicalization of German Conservatism, eriti 29-39, 149-150, 174-175). 
hästi unustuse hõlma vajunud kui ka - ühtaegu - küllalt sümboolne. Tsunftimälu pole seda alles 1960. aastail publitseeritud teksti annaalidesse kandnud. Ajaloofilosoofina on Nietzsche aastail 1991-2000 siiski elanud üle pretsedenditu tõusuaja, soliidsemates kõrgkooliõpikutes ja tekstiantoloogiates on leidnud tema mõtted ajaloost väljapaistva koha. Erakordse intensiivsusega on praegu käimas teaduslik Nietzsche-retseptsioon Venemaal, 2001. aasta suvel korraldati näiteks Peterburis esinduslik rahvusvaheline Nietzsche-konverents ${ }^{231}$ käivitunud on uurimuste projekt "Maailma nietzscheaana". "Postmodernismiga", mille prohvetina Nietzschet sageli kujutatakse, samuti XIX ja XX sajandi lõpu kultuurikriitika "analoogiatega", mida tõmmatakse niisama sageli, ei tarvitse seda kõike automaatselt või konjunktuurselt siduda. Ometi on seda pidevalt tehtud, kusjuures nii või teisiti (kultuuri)poliitilise tagamõttega, (ajaloo)ideoloogilise eelistusega - poolt või vastu. Teatud rahvuslikud erisused, näiteks saksa ja prantsuse Nietzsche-retseptsioonis, on seletatavad ka filosoofilis-kirjanduslike traditsioonide ja sotsiaalsete mõttestiilidega, erinevate "diskursustega". Prantsuse neostrukturalismiga samaaegselt "kerkib taustal üleelusuuruselt esile Nietzsche kuju": "See, kes siin jutule pääseb, on naerva mõistuse Nietzsche, mitte uue müüdi looja." ${ }^{232}$ Angloameerika vaimses maailmas on Nietzsche saanud fenomenist peaaegu modernsusjärgse mõtte "kreedoks": "Nietzsche on kahtlemata (undoubtedly) tähtsaim XIX sajandi mõtleja postmodernismi suhtes.",233

Ajaloolaste hulgas on autoriteete, kes usutunnistuslikku suhet Nietzschesse ei jaga, nii näiteks on vastukriitikat teinud Kanti "valgustusprojekti" poliitikat kaitsev ajalookirjutuse teoreetik Jörn Rüsen: "Nietzsche on nihkunud postmodernse, mõistuse hävitusest lummatud intellektuaalse avangardi juhtkujuks." ${ }^{234}$ Rüseni tuginemine neomarksist Lukácsi 1950. aastate sõnakasutusele ("mõistuse hävitus"), millega käis kaasas "Nietzsche filosoofia" ideoloogiline kuulutamine "sotsialistliku humanismi" vastu sihitud "imperialistlikuks vastandmüüdiks", 235 on märk

231 Vt Nitsshe i sovremennaya zapadnaya mysl'. Sbornik statej. Pod. red. V. Kapluna. SanktPeterburg, Moskva, Jevropeiskij universitet v Sankt-Peterburge, Letnij sad, 2003.

232 Waldenfels, B. Deutsch-Französische Gedankengänge. Frankfurt a. M., Suhrkamp Verlag, 1995, 200.

233 The Routledge Critical Dictionary of Postmodern Thought. Ed. by St. Sim. New York, Routledge, $1999,325$.

234 Rüsen, J. Strukturen historischer Sinnbildung. - Geschichtsbewusstsein der Deutschen. Materialien zur Spurensuche einer Nation. Hrsg. von W. Weidenfeld. 2. Aufl. Köln, Verlag Wissenschaft und Politik, 1989, 54. (Eesti keeles: Rüsen, J. Ajaloolise mõtestamise struktuurid. [Tlk M. Kivimäe.] - Tuna. Ajalookultuuri ajakiri, 1999, 2, 29-36, siin 30.)

235 Vt Lukács, G. Die Zerstörung der Vernunft. Der Weg des Irrationalismus von Schelling zu Hitler. Berlin, Aufbau-Verlag, 1955, 244-317, siin 316. - Autor lõpetas selle mahuka teose 1952. aastal, kuid eeltööd kuuluvad aastatesse 1933-44, mil ta viibis emigrandina "Stalini riigis" NSV Liidus (seal kaitses ta 1940-ndate algul ühtlasi oma uue, "marksistliku" doktorikraadi Hegeli alalt). Lukácsi jämemarksistlike lihtsustuste ja kultuurifilosoofilise skematismi tõttu on raamatut peetud (väljaspool NSV Liitu, kus seda 1958. aastal tauniti kui "natsionalismi" ja "revisionismi" ning 1989. aastal ülistati kui "antifašismi" näidist) tema toodangus kõige ebaõnnestunumaks teoseks. Meie aja teadusliku Nietzsche-renessansi atmosfääris on Lukácsi "vasakpoolne" käsitlus Nietzschest sama odioosne kui Baeumleri "parempoolne" töötlus, ainult et võrreldes viimasega jätab Lukács endast Nietzsche suhtes, keda Baeumler pidas maailmakirjanduses Dantega kõrvutatavaks autoriks, vähem kriitiku ja rohkem kritikaani mulje. 
stalinismiaja negatiivse Nietzsche-retseptsiooni järelmõjust ajaloolaskonnas veel aastail 1987/89. Et paljud kriitilise sotsiaalajaloo viljelejad on poliitilistelt vaadetelt sotsiaaldemokraadid, siis etendab nende puhul osa ka revisionisti kuulsusega Lukácsi - "sotsiaal-moraalses" suhtes - antud Nietzsche-määratlus tema 1947. aasta olulises essees "Aristokraatlik ja demokraatlik maailmavaade": Nietzsche väljendab "antidemokratismi" tihedat seost "antiprogressiivsusega". ${ }^{236}$ See essee esitab vastandleeride mustvalge skeemi, nii et sotsiaalset maailma valitseb "inimkonnatähtsates asjades" ideoloogiliste põhitüüpide alaline konfrontatsioon: progress, optimism, demokraatia versus progressivaen koos "ürgseisundi restitutsiooni" sooviga, ühiskondlik pessimism, aristokratism. Nietzsche vaimuajaloolise tähenduse uuemate ja positiivsete teaduslooliste interpretatsioonide taga on seevastu rahvusvahelise Nietzsche-uurimise viimaste aastate edusammud, mis lubavad kõnelda tema pärandi aktuaalsusest meie ajajärgu enesekäsitusele. ${ }^{237}$ Meie enesekäsituse meedium ja ühtlasi peegel on ka ajalookirjutus, ja sellegi teoreetilisel avanemisel on olemas varasemast märksa rohkem Nietzschega arvestavaid nihkeid. Näiteks ülalviidatud Jörn Rüseni algselt erialaleksikonile kirjutatud artikkel "Ajaloo teooria" (1990/94) lülitab ta "ajaloolise vormimise" teooriate genealoogiasse, mille väljenduseks on muu hulgas ka "historiograafiliste kujutamisvormide või ajalooalaste mõtestamisvõimaluste tüpoloogia (Droysen, Nietzsche, H. White, Rüsen)". ${ }^{238}$ On ka täiesti mõeldav liigitada need nihked samasse "mineviku avastamise" rubriiki, mille eest astus välja hiline Wittram juba osundatud tekstikohas Nietzschele toetudes.

Lõpetuseks tuleb öelda mõni sõna Nietzsche asetusest Wittrami tekstides, sest see on oluline igasuguse võimalikult objektiivset mõistmist taotleva interpretatsiooni struktuuris. Käesolev analüüs, mida sai algul nimetatud esialgseks kontuurjooniseks, ei ole ka midagi lõplikku ega täielikku, see põhineb autoritekstide representatiivsel valikul. Analüüsi tulemus lubab panna küsimuse alla ühe või teise historiograafilise traditsiooni seisukoha ja ühtlasi väita, et mõni neist seisukohtadest vajab teaduslikku korrektsiooni. Üksikuil juhtudel sisaldab Wittramiuurimine ka poliitilisi hinnanguid, mis tuleb ebakorrektseina "peatada", see tähendab, et teadusliku profiiliga kirjanduses pole kohane neile "tugineda". Teadusliku, hermeneutilise historismi eesmärkide hulka kuulub mineviku autori võtmine kaasakõnelemise õiguslikuna meie kaasaja vaidlustes ja probleemides, seega laieneb talle dialoogi eetika. ${ }^{239}$

236 Vt Lukács, G. Aristokratische und demokratische Weltanschauung (1947). - Ders., Schriften zur Ideologie und Politik, 404-433, eriti $417 \mathrm{jj}$.

237 Vt nt Ries, W. Nietzsche zur Einführung. 6., überarb. und erw. Aufl. Hamburg, Junius Verlag, 2001. (Autor on promoveerunud tööga Nietzsche retseptsiooniloo alalt ja annab samas ka kommenteeritud lühiülevaate etapilise tähtsusega sekundaarkirjandusest.)

238 Rüsen, J. Theorie der Geschichte. - Ders., Historische Orientierung. Über die Arbeit des Geschichtsbewusstseins, sich in der Zeit zurechtzufinden. Köln, Weimar, Wien, Böhlau Verlag, 1994, 80.

239 Vt selle kohta: Scholtz, G. Zum Historismusstreit in der Hermeneutik. - Historismus am Ende des 20. Jahrhunderts, 192-214. 
Reinhard Wittrami peaaegu 35-aastast aegruumi täitvais ajalooteaduslikes ja rahvuspoliitilis-publitsistlikes tekstides on Nietzsche juuresolek kahesugune. Eristada tuleb esmajoones (1) otsest tuginemist Nietzschele, tema tsitaate ja Wittrami viiteid temale ning seejärel täheldada (2) nietzschelike motiivide olemasolu Wittrami töödes, ilma et Nietzschet oleks otseselt mainitud. Esimese punkti juures on vaja omakorda teha vahet sellel, kas viide Nietzschele kannab Wittramil (a) programmilist tähendust, millega püütakse baltlaste ajalooteadvust mobiliseerida, juhtides tähelepanu uutele probleemidele, või osutatakse Nietzschele (b) historiograafilis-teadusloolise sisuga kontekstis, millel ei ole programmilist või üleskutsuvat iseloomu ja selles annab tooni pigem konstateeriv kui väitlev mõttelaad. Tundub, et alles nende eristuste hoolikas jälgimine võib anda mõnevõrra kindlama aluse, vastamaks meid siinkohal huvitavale küsimusele, (3) mis mõttes ja mille suhtes näib olevat õigustatud Friedrich Nietzsche nimetamine Wittrami Gewährsmann'iks, tema "käendajaks" või "tunnistajaks", või ka - uuemas tähenduses - "autoriteediks". ${ }^{240}$ Historistliku teadvuse konstitutsioonist aga tuleneb, et autoriteetsuski (mõõduandvus) on suhtelise väärtusega, ajalist tingitust eirates satutakse dogmaatilise meelelaadi kütkesse. Võib öelda, et Wittramile ei olnud Nietzsche siiski ainult ühe teose autor ja üksnes 2. "ajakohatu" ajalookriitik, teda on huvitanud Nietzsche vaated ajaloole ka väljaspool seda traktaati. Et aga see Nietzsche traktaat, kriitilise ajaloomõtlemise üks väljapaistvamaid dokumente kogu modernses kultuuris, on olnud Wittrami tasemega ajaloolase inspiratsiooniallikas, siis on meil õigus lugeda Nietzschet (mõju)teguriks balti regionaalses ajalookultuuris. Historismi probleemajaloolise nägemisviisi rekonstruktsioonile Baltikumis, ajaloolise relativismi kui modernse kultuuri ühe põhiprobleemi teaduslikule läbitöötamisele, on Wittrami Nietzsche-kontaktil otsustav tähendus. Seetõttu ei ole uurimises nii oluline apelleerida sellele, et kontakt on olnud (sotsiaalfakt), vaid eelkõige sellele, et kontakt oli teose läbi (kultuurifaktina) tähendusrikas. Nietzsche pole Wittrami suhtes lihtsalt käendaja või autoriteet, kes midagi tagab või keda milleski nagu mõõdupuud järgitakse, vaid sellest rohkemat ja sisukamat - Nietzsche on Wittrami tähendusrikas tunnistaja.

Autentsuse probleem on mõnes suhtes nagu konksuga küsimus, mõtteallikale ei saa meil olla vahetut ligipääsu autentsuse määramiseks, mõnikord tuleb ka eeldada, et mõte "esitab" autorit, "iseloomustab" Wittramit, nagu tema nimi ja selle nimega samastatav isikulugu. Positsioon, mis sellisest väitest tuleneb, on kõikumine usalduse ja kriitika vahel seetõttu, et seni puudub Wittrami-filoloogia ajaloolise autori tekstide saamisloo analüüsi mõttes. Võimalik, et Wittrami kui autori oma nägu on meie endi senine "eelarvamus" ja "algsuunitlus", mis rajaneb üldiselt teadaoleval, aga ei haara autori identiteeti nii, et see oleks jälgitav tema eneseotsinguna, kogu tema vastuolulise teadusliku, moraalse ja poliitilise arengu protsessina. Autori identiteedi vaatlemisel protsessina on vähemalt see eelis, et me

240 Gewährsmann on "Dudeni” järgi 'keegi, kelle põhjendatud väitele [lausungile, väljendile, sõnadele] toetutakse' (vt Duden Deutsches Universalwörterbuch. Hrsg. und bearb. unter Leitung von G. Drosdowski. Mannheim, Wien, Zürich, Dudenverlag, 1989, 605). 
läheneme talle kui "objektile" teadmisega, et subjekt on juba teataval määral kaotsi läinud, sest me ise ei saa enam "kuuluvuse" kaudu jagada selle traditsiooni tingimusi, mis on osa tema subjektiivsusest - ja et me oleme tema suhtes alati teised. Uuem kultuuriteadus on osutanud, et sel teistsugususel on samuti olemas kaks aspekti. Gadameri väitel "meetodi" juurde kuuluv "elusideme lagunemine" (Auflösung einer Lebensbindung), see objektiks muutev "distants", ${ }^{241}$ ei pruugi siin lõppastmes olla ainult või tervikuna võõrandav barjäär. Lotmani-Uspenski järgi toimub väljapaistvate isiksuste puhul "kultuuriloolise reaalsuse avanemine" selle kahe (mütoloogilise ja ajaloolise) mõõtme ühtsuses, mitte vastanduses. ${ }^{242}$ Mõistagi on sellel Herderi kaasaegse Karamzini vaatluse ajendil esitatud ideel oma rakendusala muudelgi, järgnevail ajastuil, XX sajandit oma "mütologismiga" ning mütologismi ja historismi vahelise väitlusega pole küll võimalik neist ajastuist välja arvata. ${ }^{243}$ Niisiis tundub, et autentsus ei saa olla lihtsalt ajalooline faktilisus või faktilise sedastamise täpsus, vaid pidev hool autori omanäolisuse suurenemise eest selle määrani, kus teine muutub konkreetse autorina, ajas teisena ning seega endana üha enam äratuntavaks. Kasulik näib resubjektiveeriv lähenemisviis olevat Wittrami, tema maailmavaate ja teadusloomingu seoste uurimisel ka põhjusel, et selle teemade ringis on domineerinud kas sotsiaalpoliitiline või rahvusideoloogiline tüpiseerimine.

241 Gadamer, H.-G. Wahrheit und Methode. Der Anfang der Urfassung (ca 1956). Hrsg. von J. Grondin und H.-U. Lessing. - Dilthey-Jahrbuch für Philosophie und Geschichte der Geisteswissenschaften, 1992/93, 8, 137.

Vt Lotman, J. M., Uspenski, B. A. "Pisma russkogo puteshestvennika" Karamzina i ikh mesto v razvitii russkoj kultury. - Karamzin, N. M. Pisma russkogo puteshestvennika (Literaturnye pamjatniki). Izd. podgot. J. M. Lotman, N. A. Marchenko, B. A. Uspenski. Leningrad, Izdatel'stvo "Nauka", 1987, 525 jj.

Vt XX sajandi mütologismi kohta üldistavalt näiteks Eleazar Meletinski kokkuvõtet: Meletinski, E. M. Mif i dvadtsatyj vek. - Id., Izbrannye stat'i. Vospominaniya. Moskva, Rossiiskij gosudarstvennyj gumanitarnyj universitet, 1998, 419-426, kus õigusega on ka viidatud, et mütologiseerimine on olnud historiseerumise vastu suunatud abinõu (423 jj): "Paralleelselt lahtiütlemisega sotsiaalsest historismist filosoofias, teaduses (sh etnoloogias) ning kunstis toimus mütoloogia 'rehabiliteerimine' ja apologeetistamine inimolemise ning inimpsüühika aluste igavese sümboolse väljendusena, sõltumata ajaloolistest asjaoludest ja konkreetsetest karakteritest." Autor seostab selle "pöörde" - mütologism vs historism - otseselt Nietzsche "ettevalmistava" mõjuga, kuid jätab tähelepanuta teise olulise aspekti: Nietzschel on müüt ka ajaloo tõlgendamise vahend. Müüt korvab selle, mis teaduse mõjul jääb eksistentsi seletuses puudu; ta kompenseerib "puhtpositivistliku teaduse võimetust anda inimesele kätte tõlgendusmuster selleks, mida ta elab ja läbi elab" (Lange, W. Tod ist bei Göttern immer nur ein Vorurteil. Zum Komplex des Mythos bei Nietzsche [1983]. - Mythos und Moderne. Begriff und Bild einer Rekonstruktion. Hrsg. von K. H. Bohrer. Frankfurt a. M., edition suhrkamp, 1989, 120). Wittram on (seoses Rothackeriga) märkinud: "Üheks 'keskseks juhtmõtteks', mis võib relativismi ohtu tõrjuda või leevendada, osutub filosoofilisele interpreedile küsimise eelteaduslik iseloom, mille taga seisab teaduseelse huvitatuse vabadus. Argumendil on kaalu." Teisalt on ta näinud "ebaehtsa ajalooteadvuse" teket ja ohte mineviku "kunstlikus aktualiseerimises" poliitilise võimu dünaamika tõttu, nii et müüdivaba ajaloo(teaduse) kaitseks tuleb arvesse üksnes kultuurilooline argument: “'Müüdita ajalugu' (E. Weniger) - see on ammu demütiseeritud Õhtumaa aususe nõue.” (Wittram, R. Das Interesse an der Geschichte, 62 ja 65.) 
Kui käesoleva artikli alguses sai Nietzsche ja Benjamini võrdluses märgitud, et kultuurilooga tegelemine sarnaneb tõeste piltide otsimisega müüdimaastikul, siis nü̈̈d võiksime juurde lisada järgmist. Wittrami Nietzsche-konteksti avamisel osutub, et "isiksus" esineb kultuuris ka selle "tekstina" juba muutunud olekus, kahte moodi või kahekordse perspektiivi valguses: temast jutustavate müütide ja tema kirjutatud teoste erinevas retseptsioonis. Seega on meil tegemist tunnetava isiku, "tunnetaja" enda hoiakuga, ja paistab olevat õige, et kui me sellegagi arvestame, siis "me ei saa jääda seisma historiograafia unitaarse mõiste juurde, vaid peame Nietzsche traktaadi "Ajaloo kasust ja kahjust elule" eeskujul silmas pidama selle lõhustumist võimaliku ajalookäsituse tüüpideks". ${ }^{244}$ Tunnetaja hoiakusse võib aga seejuures niisama hästi kuuluda vana, XIX sajandi historismi algajast pärinev individuaalsusidee, mis kattub meie ajal respektimõistega, kui tegu on nüüdisuurija teadliku sooviga respekteerida teises ajasituatsioonis olnud ajaloolase individuaalsust. Sel juhul ei lähtu nüüdisuurija päriselt ja ainult oma küsimus(t)est, nagu tavaliselt rõhutatakse, vaid tema lähtepunkt on ajalooliselt teist puudutava küsimusteringi rekonstruktsioon, nagu eelnevas püüti taastada küsimust Reinhard Wittrami suhtest Nietzsche pärandiga.

244 Kuhn, H. Wahrheit und geschichtliches Verstehen. Bemerkungen zu H.-G. Gadamers philosophischer Hermeneutik. - HZ, 1961, 193, 385.

\section{LEBENSPHILOSOPHIE UND GESCHICHTSWISSENSCHAFT IM BALTIKUM: \\ NIETZSCHE ALS REINHARD WITTRAMS 'GEWÄHRSMANN' \\ Ein Beitrag zur Nietzsche-Rezeption der Historiker und zugleich zur Problematik der sog. Historismuskrise}

\section{Mart KIVIMÄE}

Der Aufsatz behandelt den Historismus als einen neu zu erschliessenden Problembereich in der politischen und wissenschaftlichen Kultur des baltischen Deutschtums vor und nach 1945. Im Mittelpunkt steht das Historismusverständnis des führenden deutschbaltischen Historikers und Theoretikers der Geschichtswissenschaft Reinhard Wittram (1902-1973), das anhand einer kritischen Interpretation seiner historisch-politischen Publizistik und seiner wichtigsten wissenschaftlichen Vorträge der 1920er/1930er sowie der 1950er/1960er Jahre in Umrissen dargestellt wird. Die frühe dualistisch-dramatische Idee der Geschichte löst sich bei Wittram später in einer reiferen Denkform auf, die nach seinem höchst eigenständigen nichtmarxistischen Begriffsgebrauch vielleicht 'dialektischer Historismus' genannt werden kann. Damit wird Wittram als ein bis heute beachtenswerter Geschichtsdenker, dessen Bild in der Historiographie von der nationalsozialistischen 
Vergangenheit leider stark belastet ist, wieder in den heutigen Historismusdiskurs integriert. Zum Beispiel darunter auch auf das Niveau der Diskussionen der 1990er Jahre zwischen Jörn Rüsen und Otto G. Oexle gebracht, weil diese ehemalige Kritik, die Wittram am Historismuskonzept Friedrich Meineckes übte, ist teilweise aktuell geblieben. Vor allem wird hier aus der problemgeschichtlichen Perspektive die Entwicklung Wittrams 'Axiome' diskutiert: seine schon früh differenzierte, wenn nicht sogar durchaus ambivalente Auffassung vom Historismus überhaupt, unter dem er nicht nur einen Grundbegriff der modernen Historie, sondern auch nach dem Vorbilde von Nietzsche und Ernst Troeltsch eine Schlüsselfrage bzw. ein Lebensproblem der ganzen gegenwärtigen Kultur verstand. Besondere Aufmerksamkeit verdient dabei der wittramsche NietzscheKontext, die Rezeption der lebensphilosophischen Historismuskritik Friedrich Nietzsches, deren sehr entscheidende, wiederkehrende Motive seit 1934 bis 1969 aufgrund der vergleichenden Textanalyse in dieser Untersuchung aufgehellt werden. Neben dem ganz berechtigten politisch-demokratischen Kritik in Sachen der sog. Naziperiode Wittrams darf man jedoch nicht vergessen, dass Wittrams fast erbarmungslose Selbstkritik wegen seines einstigen Nationalismus im Rahmen der Volksgeschichte, mit der er die 'Gefahr' des historischen Relativismus neutralisieren versuchte, später ein bedeutsames Wegzeichen ist. Es ist ein Merkmal, das zeigt, wie er einen schweren Weg ging, der ihn von der durch die neukonservativen geschichtsideologischen Züge charakterisierbare Volksmetaphysik über eine nachkriegszeitliche Existenzkrise zu einem im Grunde freiheitlichen kulturell-politischen Pluralismus brachte. Das aber heisst, ihn zur prinzipiellen Umwertung des Ideenkomplexes des Nationalen im europäischen Kulturraum führte. Die Sphäre des Historistischen und ihrer Analyse dient somit bei Wittram zur Erklärung seiner widersprüchlichen politischen Tätigkeit, Nietzsches 'berühmte Warnung' blieb ihm in Fragen des Gleichgewichts zwischen Leben und Geschichte aber bis zu Ende seiner wissenschaftlichen Karriere relevant. 